\title{
Nomenclature of the hydrotalcite supergroup: natural layered double hydroxides
}

\author{
S. J. Mills ${ }^{1, * \dagger}$, A. G. Christy ${ }^{2,}$, J.-M. R. Génin ${ }^{3}$, T. Kameda ${ }^{4}$ and F. Colombo ${ }^{5}$
}

${ }^{1}$ Geosciences, Museum Victoria, GPO Box 666, Melbourne 3001, Victoria, Australia

2 Centre for Advanced Microscopy, Sullivans Creek Road, Australian National University, Canberra 0200, ACT, Australia

3 Institut Jean Barriol FR2843, CNRS-Université de Lorraine, ESSTIN, 2 rue Jean Lamour, F-54500 VandoeuvreLès-Nancy, France

4 Graduate School of Environmental Studies, Tohoku University, 6-6-07 Aoba, Aramaki, Aoba-ku, Sendai 980-8579, Japan

5 Cátedra de Geología General, Facultad de Ciencias Exactas, Físicas y Naturales, Universidad Nacional de Córdoba, Vélez Sarsfield 1611, Córdoba, Argentina

[Received 23 August 2012; Accepted 2 October 2012; Associate Editor: G. Diego Gatta]

\section{ABSTRACT}

Layered double hydroxide (LDH) compounds are characterized by structures in which layers with a brucite-like structure carry a net positive charge, usually due to the partial substitution of trivalent octahedrally coordinated cations for divalent cations, giving a general layer formula $\left[\left(M_{1-x}^{2+} M^{3+}{ }_{x}\right)(\mathrm{OH})_{2}\right]^{x+}$. This positive charge is balanced by anions which are intercalated between the layers. Intercalated molecular water typically provides hydrogen bonding between the brucite layers. In addition to synthetic compounds, some of which have significant industrial applications, more than 40 mineral species conform to this description. Hydrotalcite, $\mathrm{Mg}_{6} \mathrm{Al}_{2}(\mathrm{OH})_{16}\left[\mathrm{CO}_{3}\right] \cdot 4 \mathrm{H}_{2} \mathrm{O}$, as the longestknown example, is the archetype of this supergroup of minerals. We review the history, chemistry, crystal structure, polytypic variation and status of all hydrotalcite-supergroup species reported to date. The dominant divalent cations, $\mathrm{M}^{2+}$, that have been reported in hydrotalcite supergroup minerals are $\mathrm{Mg}, \mathrm{Ca}, \mathrm{Mn}, \mathrm{Fe}, \mathrm{Ni}, \mathrm{Cu}$ and $\mathrm{Zn}$; the dominant trivalent cations, $\mathrm{M}^{3+}$, are $\mathrm{Al}, \mathrm{Mn}, \mathrm{Fe}, \mathrm{Co}$ and $\mathrm{Ni}$. The most common intercalated anions are $\left(\mathrm{CO}_{3}\right)^{2-},\left(\mathrm{SO}_{4}\right)^{2-}$ and $\mathrm{Cl}^{-}$; and $\mathrm{OH}^{-}, \mathrm{S}^{2-}$ and $\left[\mathrm{Sb}(\mathrm{OH})_{6}\right]^{-}$have also been reported. Some species contain intercalated cationic or neutral complexes such as $\left[\mathrm{Na}\left(\mathrm{H}_{2} \mathrm{O}\right)_{6}\right]^{+}$or $\left[\mathrm{MgSO}_{4}\right]^{0}$. We define eight groups within the supergroup on the basis of a combination of criteria. These are (1) the hydrotalcite group, with $M^{2+}: M^{3+}=3: 1$ (layer spacing $~ 7.8 \AA$ ); (2) the quintinite group, with $M^{2+}: M^{3+}=2: 1$ (layer spacing $\sim 7.8 \AA$ ); (3) the fougèrite group, with $M^{2+}=\mathrm{Fe}^{2+}$, $M^{3+}=\mathrm{Fe}^{3+}$ in a range of ratios, and with $\mathrm{O}^{2-}$ replacing $\mathrm{OH}^{-}$in the brucite module to maintain charge balance (layer spacing $\sim 7.8 \AA$ ); (4) the woodwardite group, with variable $M^{2+}: M^{3+}$ and interlayer $\left[\mathrm{SO}_{4}\right]^{2-}$, leading to an expanded layer spacing of $\sim 8.9 \AA$; $(5)$ the cualstibite group, with interlayer $\left[\mathrm{Sb}(\mathrm{OH})_{6}\right]^{-}$and a layer spacing of $\sim 9.7 \AA$; (6) the glaucocerinite group, with interlayer $\left[\mathrm{SO}_{4}\right]^{2-}$ as in the woodwardite group, and with additional interlayer $\mathrm{H}_{2} \mathrm{O}$ molecules that further expand the layer spacing to $\sim 11 \AA$; (7) the wermlandite group, with a layer spacing of $\sim 11 \AA$, in which cationic complexes occur with anions between the brucite-like layers; and (8) the hydrocalumite group, with $M^{2+}=\mathrm{Ca}^{2+}$ and $M^{3+}=\mathrm{Al}$, which contains brucite-like layers in which the Ca:Al ratio is $2: 1$ and the large cation, $\mathrm{Ca}^{2+}$, is coordinated to a seventh ligand of 'interlayer' water.

\footnotetext{
* E-mail: smills@museum.vic.gov.au

$\dagger$ Chair of CNMNC sub-commission on hydrotalcite group nomenclature

* Vice-chair of CNMNC sub-commission on hydrotalcite group nomenclature

DOI: $10.1180 /$ minmag.2012.076.5.10
} 
The principal mineral status changes are as follows. (1) The names manasseite, sjögrenite and barbertonite are discredited; these minerals are the $2 H$ polytypes of hydrotalcite, pyroaurite and stichtite, respectively. Cyanophyllite is discredited as it is the $1 M$ polytype of cualstibite. (2) The mineral formerly described as fougèrite has been found to be an intimate intergrowth of two phases with distinct $\mathrm{Fe}^{2+}: \mathrm{Fe}^{3+}$ ratios. The phase with $\mathrm{Fe}^{2+}: \mathrm{Fe}^{3+}=2: 1$ retains the name fougèrite; that with $\mathrm{Fe}^{2+}: \mathrm{Fe}^{3+}=1: 2$ is defined as the new species trébeurdenite. (3) The new minerals omsite (IMA2012025), $\mathrm{Ni}_{2} \mathrm{Fe}^{3+}(\mathrm{OH})_{6}\left[\mathrm{Sb}(\mathrm{OH})_{6}\right]$, and mössbauerite (IMA2012-049), $\mathrm{Fe}_{6}^{3+} \mathrm{O}_{4}(\mathrm{OH})_{8}\left[\mathrm{CO}_{3}\right] \cdot 3 \mathrm{H}_{2} \mathrm{O}$, which are both in the hydrotalcite supergroup are included in the discussion. (4) Jamborite, carrboydite, zincaluminite, motukoreaite, natroglaucocerinite, brugnatellite and muskoxite are identified as questionable species which need further investigation in order to verify their structure and composition. (5) The ranges of compositions currently ascribed to motukoreaite and muskoxite may each represent more than one species. The same applies to the approved species hydrowoodwardite and hydrocalumite. (6) Several unnamed minerals have been reported which are likely to represent additional species within the supergroup.

This report has been approved by the Commission on New Minerals, Nomenclature and Classification (CNMNC) of the International Mineralogical Association, voting proposal 12-B.

We also propose a compact notation for identifying synthetic LDH phases, for use by chemists as a preferred alternative to the current widespread misuse of mineral names.

KEYwords: LDH, layered double hydroxide, hydrotalcite, hydrotalcite supergroup, brucite, nomenclature, manasseite, sjögrenite, barbertonite, cyanophyllite, fougèrite, trébeurdenite.

\section{Introduction}

THE layered double hydroxides (LDHs) are a large class of natural and synthetic compounds whose layered structure is derived from that of brucite, $\mathrm{Mg}(\mathrm{OH})_{2}$. In LDHs, two cations of different charge substitute on the sites corresponding to the $\mathrm{Mg}$ of brucite to give an overall positive charge to the hydroxide layer. The positive charge is balanced by monatomic or small complex anions which are intercalated between the layers. The interlayer species are loosely bound and can be exchanged readily (e.g. Meyn et al., 1990). This ability to exchange anions between the positively charged structural layers contrasts with the exchange of interlayer cations in silicate clays and channel cations in zeolites (Amphlett, 1958; Carroll, 1959; Barrer, 1978) and many other classes of microporous materials with heteropolyhedral polyhedral frameworks (cf. Ferraris et al., 2004; Ferraris and Merlino, 2005), which have negatively charged structural frameworks. All synthetic and many natural examples of the LDHs occur as clay-sized crystals with large surface area to volume ratios (Meyn et al., 1990). They have therefore become important to industry, and have found uses as catalysts, drug delivery media, and sequestering agents for organic polymers and $\mathrm{CO}_{2}$ (Duan and Evans, 2006; Kameda et al., 2011a,b). Oxyanion adsorption and other properties of LDH compounds are reviewed by Goh et al. (2008). Organically modified LDH phases prepared by the intercalation of organic anions into the interlayer of the LDH can absorb heavy metal ions and non-ionic organic compounds from aqueous solutions (Kameda and Yoshioka, 2011). Other potential applications of organically modified LDHs lie in the fields of catalysis, photochemistry and electrochemistry (Newman and Jones, 1998). Deprotonation of $\mathrm{OH}^{-}$ions in so-called $\mathrm{Fe}^{2+}-\mathrm{Fe}^{3+}$ 'green rust' phases is also of interest in the reduction of oxidized pollutants such as nitrates (Génin et al., 2006c, 2008).

To date, 44 minerals have been described as natural examples of LDH phases; they are commonly known to mineralogists as the 'hydrotalcites' or 'hydrotalcite group' of minerals. These phases are commonly polytypic, and there are a number of examples where distinct names have been established for different polytypes of the same compound. As a result, a sub-commission was set up to make recommendations on the future naming of these phases, to provide a group taxonomy and to suggest a nomenclature that would be useful for synthetic analogues. The findings of this commission appear in the following text, and have been approved by the Commission on New Minerals, Nomenclature and Classification (CNMNC) of the International Mineralogical Association, voting proposal 12-B. 


\section{Crystal chemistry of the hydrotalcite supergroup}

The minerals considered here all contain a structural layer based on that of brucite. The brucite structure consists of two adjacent hexagonal eutactic (geometrically 'close-packed') arrays of hydroxide anions, with $\mathrm{Mg}^{2+}$ cations filling all of the octahedral spaces between them
(Fig. 1). The $\mathrm{OH}$ groups are oriented normal to the layers, with the $\mathrm{H}$ atoms on the opposite side of the oxygen to the $\mathrm{Mg}$ atoms, so that each $\mathrm{O}$ is coordinated approximately tetrahedrally by $3 \mathrm{Mg}$ $+1 \mathrm{H}$. Layers stack so that each $\mathrm{H}$ atom in one layer points into one of the interstices between three $\mathrm{H}$ atoms in an adjacent layer. It is important to note that there is no significant H-bonding between layers at ambient pressure. If we
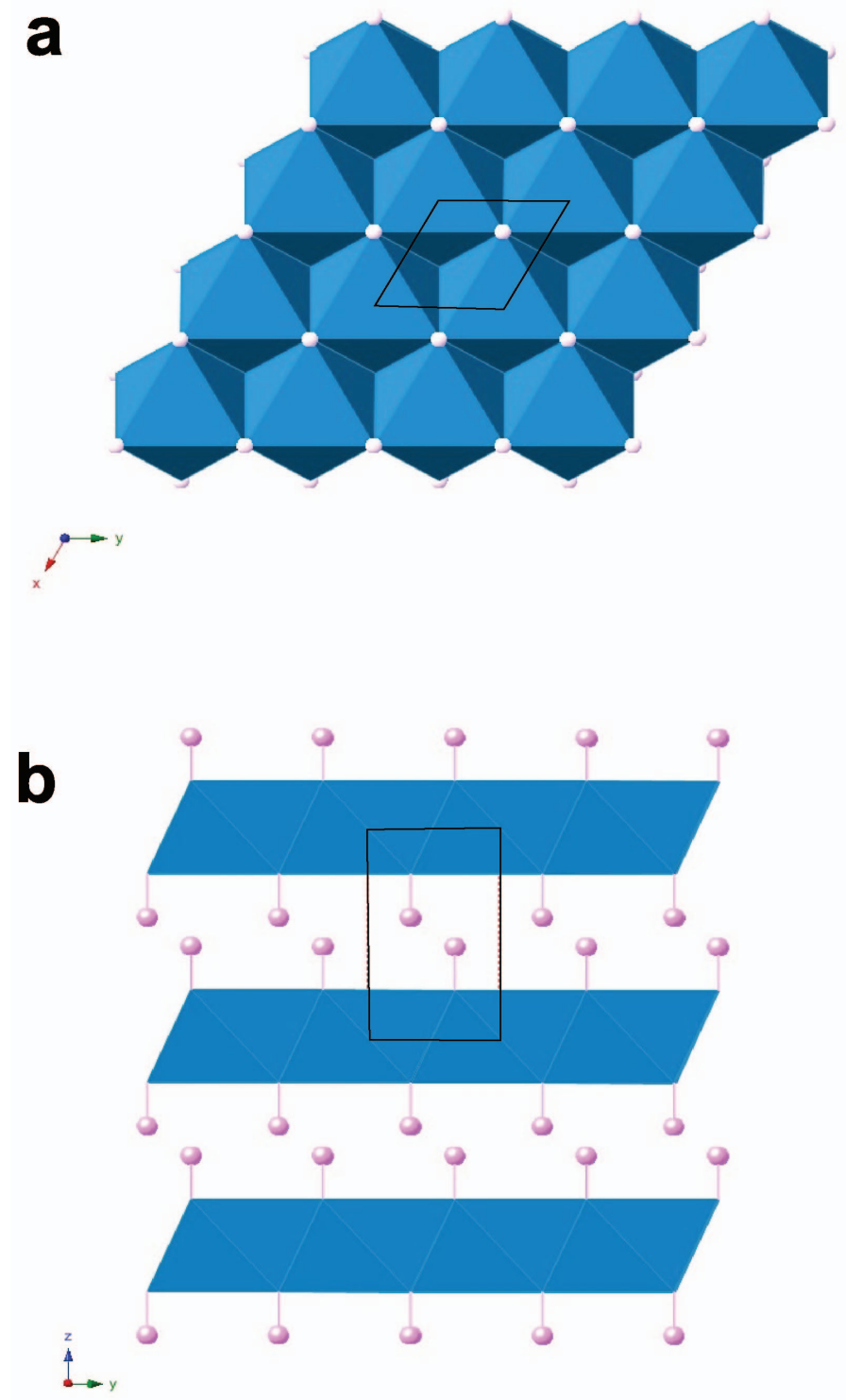

Fig. 1. Brucite structure viewed (a) down the $z$ axis and $(b)$ down the $x$ axis. The $\mathrm{MgO}_{6}$ octahedra are shown as polyhedra, $\mathrm{H}$ is shown as small spheres. The unit cell is indicated by the black outline. 
represent the possible $x y$ offsets of close-packed layers as $A, B, C$ for the oxygens and $\alpha, \beta, \gamma$ for the magnesium atoms, the overall stacking sequence can be described as ...C $\alpha B-C \alpha B-$ $C \alpha B \ldots$, giving a one-layer trigonal structure, with space group $P \overline{3} \mathrm{~m} 1$, and unit-cell dimensions of $a=3.147$ and $c=4.769 \AA$, with $Z=1$ (e.g. Zigan and Rothbauer, 1967). Isostructural hydroxides include amakinite (Wyckoff, 1963: p. 239-444), portlandite (Henderson and Gutowsky, 1962), pyrochroite (Parise et al., 1998) and theophrastite (Ramesh et al., 2006), which are the $\mathrm{Fe}^{2+}, \mathrm{Ca}^{2+}, \mathrm{Mn}^{2+}$ and $\mathrm{Ni}^{2+}$ analogues, respectively.

The layers in brucite are electrostatically neutral. The LDH phases differ in that some of the octahedral $\mathrm{M}^{2+}$ cations are replaced by $\mathrm{M}^{3+}$ cations, producing layers with a net positive charge. This is balanced by negatively charged species in an expanded interlayer space, which can also accommodate water molecules and a resultant network of hydrogen bonds between layers. A distinctive feature of the expanded layers in the least structurally complex members of the supergroup, which have interlayer carbonate, is that the $\mathrm{OH}$ groups of adjacent brucite layers are aligned directly over one another rather than being offset. The $\mathrm{O}-\mathrm{H}$ bonds are not necessarily aligned parallel to $c$ (cf. Krivovichev et al., 2010a). This arrangement presumably optimizes hydrogen bonding to the interlayer species.

Maximum degree of order (MDO) stacking sequences were defined by Dornberger-Schiff (1982) as those in which all layer pairs, triplets and $n$-tuples are geometrically equivalent. For the LDH structures considered here, these are ... $C \alpha B-X-B \alpha C-X-C \alpha B-X-B \alpha C \ldots$ and $\ldots C \alpha B-X-B \gamma A-X-A \beta C-X-C \alpha B \ldots$, giving 2-layer hexagonal and 3-layer rhombohedral structures, with maximum possible space-group symmetries of $P 6_{3} / \mathrm{mmc}$ and $R \overline{3} \mathrm{~m}$, respectively (Fig. 2). In this scheme, $X$ is defined as the interlayer ions and water.

FIG. 2. Hydrotalcite structure viewed down the $x$ axis for (a) $2 H_{1}$ polytype with $c \sim 16 \AA$ and (b) $3 R_{1}$ polytype with $c \sim 24 \AA$ A. Disordered interlayer carbonate and water is indicated by sheets of carbonate groups (red spheres $=$ oxygen, black $=$ carbon). Note that offset of $\mathrm{H}$ atoms across the interlayer is different from that in brucite and that alternate brucite layers are rotated relative to one another about $z$ by $180^{\circ}$ in (a), but are translationally equivalent in $(b)$. a
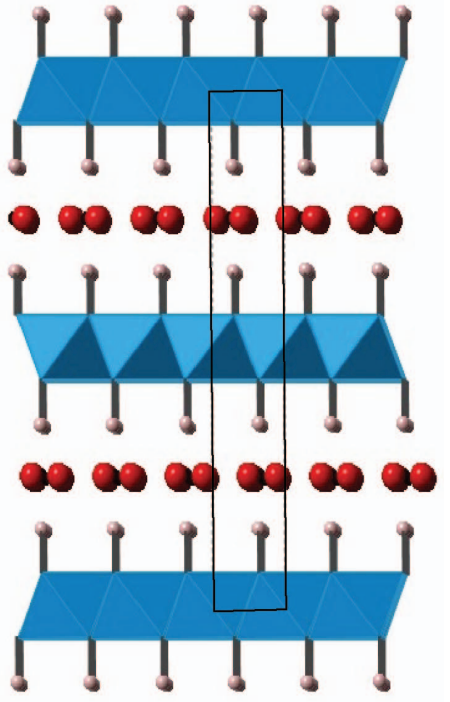

\rfloor$_{-y}^{z}$

b
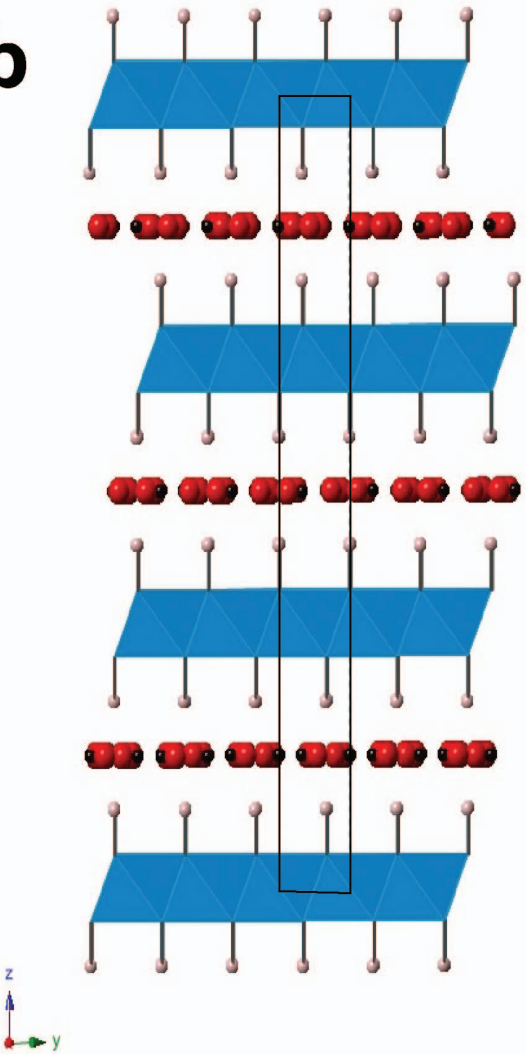
Hydrotalcite-supergroup minerals and LDHs are well known for the wide range of polytypism which they exhibit. The nature of this polytypism was discussed by Bookin and Drits (1993) and Bookin et al. $(1993 a, b)$, with a more recent summary by Evans and Slade (2006). Polytypism in the hydrotalcite structure-type is complex, but in the first instance arises due to the different possible ways the brucite-like layer can stack. Bookin and Drits (1993) discussed several theoretical polytypes and described the X-ray diffraction intensity criteria for distinguishing between them. These included one single-layer polytype, three 2-layer polytypes, nine 3-layer polytypes and a large number of 6-layer polytypes. The stacking sequences of Bookin and Drits (1993) include those with $\mathrm{OH}$ groups offset across the interlayer, as in brucite (Fig. 1), and those with $\mathrm{OH}$ juxtaposed across interlayers, as in the structures shown in Fig. 2; they referred to these two interlayer geometries as ' $O$ type' and ' $P$ type', respectively. A survey of X-ray diffraction data by Bookin et al. (1993a) showed that although the two MDO $P$-type structures of Fig. 2 were by far the most common, and were the only stacking sequences confirmed for the hydrotalcite group sensu stricto, other arrangements with $O$-type interlayers were present in members of the supergroup with expanded interlayers containing sulfate anions.
The greater chemical and structural complexity of the interlayer appears to allow more variability in the hydrogen-bonding pattern in such cases. The stacking sequences of Bookin and Drits (1993) with three layers or less are summarized in Table 1. The polytype notation has been revised slightly to distinguish trigonal and hexagonal crystal systems, in accord with the nomenclature scheme of Guinier et al. (1984).

The interlayer spacing of hydrotalcite supergroup minerals and LDHs depends on the nature of the interlayer species. The brucite spacing of $\sim 4.7 \AA$ increases to $\sim 7.8 \AA$ in minerals with interlayer hydroxide, halide or carbonate groups, and to 8.5-9 $\AA$ in minerals with interlayer sulfate tetrahedra. Spacings of $\sim 11 \AA$ are observed if the interlayer contains additional $\mathrm{H}_{2} \mathrm{O}$ coordinated to sulfate (e.g. the glaucocerinite group) or large, low-charge cations such as $\mathrm{Na}^{+}$and $\mathrm{Ca}^{2+}$ (e.g. the wermlandite group).

In hydrotalcite-supergroup minerals and LDHs, the $M^{2+}: M^{3+}$ ratio is generally constant, and the minerals have a strong preference for a $M^{2+}: M^{3+}$ ratio of either $3: 1$ or $2: 1$. Cation ratios greater than $3: 1$ are known, particularly in synthetic LDHs, but are less commonly observed in minerals (although brugnatellite appears to be an example). Cation ratios of less than 2:1 are uncommon for good crystal-chemical reasons. Three $M^{3+}$ cations around a single $\mathrm{OH}$ in the trioctahedral sheet of

TABLE 1. Possible hydrotalcite stacking sequences with periods of 3 layers or less. Symbols $\{A, B, C\}$ indicate offsets of hydroxide sublayers, $\{\alpha, \beta, \gamma\}$ offsets of octahedral cations, - indicates an $O$-type interlayer and $=$ a $P$-type interlayer.

\begin{tabular}{llcccc}
\hline Symbol & Layer sequence & Interlayer type & $\begin{array}{c}\text { OH sublayers } \\
\text { all equivalent }\end{array}$ & $\begin{array}{c}\text { Cation sublayers } \\
\text { all equivalent }\end{array}$ & $\begin{array}{c}\text { Maximum possible } \\
\text { space group }\end{array}$ \\
\hline $1 T$ & $A \beta C-A \beta C$ & $O$ & Yes & Yes & $P \overline{3} m 1$ \\
$2 H_{1}$ & $A \beta C=C \beta A=A \beta C$ & $P$ & Yes & Yes & $P 6_{3} / m m c$ \\
$2 H_{2}$ & $A \beta C-A \gamma B-A \beta C$ & $O$ & No & Yes & $P 6_{3} m c$ \\
$2 T^{*}$ & $A \beta C-B \gamma A=A \beta C$ & $O+P$ & No & Yes & $P \overline{3} m 1$ \\
$3 R_{1}$ & $A \beta C=C \alpha B=B \gamma A=A \beta C$ & $P$ & Yes & Yes & $R \overline{3} m$ \\
$3 R_{2}$ & $A \beta C-B \gamma A-C \alpha B-A \beta C$ & $O$ & Yes & Yes & $R \overline{3} m$ \\
$3 T_{1}$ & $A \beta C-A \gamma B-A \gamma B-A \beta C$ & $O$ & No & No & $P 3 m 1$ \\
$3 T_{2}$ & $A \beta C-A \gamma B-C \alpha B-A \beta C$ & $O$ & No & No & $P \overline{3} m 1$ \\
$3 T_{3}$ & $A \beta C-A \gamma B=B \gamma A=A \beta C$ & $O+P$ & No & No & $P 3 m 1$ \\
$3 T_{4}$ & $A \beta C-A \beta C=C \beta A=A \beta C$ & $O+P$ & No & No & $P \overline{3} m 1$ \\
$3 T_{5}$ & $A \beta C-A \gamma B=B \alpha C-A \beta C$ & $O+P$ & No & No & $P \overline{3} m 1$ \\
$3 T_{6}$ & $A \beta C-A \gamma B-C \beta A=A \beta C$ & $O+P$ & No & No & $P 3 m 1$ \\
$3 T_{7}$ & $A \beta C-A \beta C-B \gamma A=A \beta C$ & $O+P$ & No & No & $P 3 m 1$ \\
& & & & & \\
\hline
\end{tabular}

* $2 T$ was labelled " $2 H_{3}$ ” by Bookin and Drits (1993). 
a hydrotalcite-type mineral will lead to overbonding of the oxygen unless the $M-\mathrm{O}$ bonds are severely lengthened. The coordination polyhedra of these three highly-charged cations would also be sharing edges with one another, which is not favoured electrostatically. It seems likely that local ordering of $\mathrm{M}^{2+}$ and $\mathrm{M}^{3+}$ occurs to prevent the formation of such $M^{3+}$ clusters. This is, in effect, an 'aluminium avoidance principle' analogous to that invoked by Loewenstein (1954) to account for tetrahedral cation order in aluminosilicates. Triangular clusters of edgesharing $M^{3+}$ cations can be avoided at $M^{2+}: M^{3+}$ ratios of 2:1 if the $M^{2+}$ are ordered in a honeycomb pattern within the layer, giving a $\sqrt{3} \times \sqrt{3}$ superlattice in the plane of the layer (Fig. 3). For ratios of $3: 1, M^{3+}$ avoidance can be achieved without long-range order.

Within-layer ordering of $M^{2+}$ and $M^{3+}$ cations has been verified in some cases by infrared spectroscopy (e.g. Richardson and Braterman, 2007), ${ }^{1} \mathrm{H}$ and ${ }^{25} \mathrm{Mg}$ NMR spectroscopy (e.g. Sideris et al., 2008) and electron diffraction (e.g. Steeds and Morniroli, 1992). However, if the resulting superlattices of successive layers are offset in a disordered fashion, the local ordering may not be reflected in the unit cell determined by $\mathrm{X}$-ray methods. The data available to date suggests that some LDH phases show no long-range stacking order of any $x y$ superlattices; some show short-range order, giving rise to rods of diffuse scattering parallel to $\mathbf{c}^{*}$ in X-ray diffraction patterns; and others show a high degree of long-range order. Examples of all three cases have recently been reported for the mineral quintinite (Krivovichev et al., 2010a,b,c). Long-range order in some hydrotalcite-supergroup minerals has produced $x y$ superstructures with (pseudo)hexagonal unit nets (in multiples of the brucite $a$ parameter) including the following: $\sqrt{3} \times \sqrt{ } 3$ [brugnatellite (Fenoglio, 1938), pyroaurite/sjögrenite (Ingram and Taylor, 1967), stichtite (Mills et al., 2011), chlormagaluminite (Kashaev et al., 1982), zincowoodwardite (Witzke and Raade, 2000), quintinite (Arakcheeva et al., 1996; Krivovichev et al., 2010a), zincalstibite (Bonaccorsi et al., 2007)]; $2 \times 2$ [pyroaurite (Ingram and Taylor, 1967), hydrotalcite (Allman and Jepsen, 1969), reevesite (White et al., 1967; De Waal and Viljoen, 1971)]; $3 \times 3$ [carrboydite (Nickel and Clarke, 1976), motukoreaite (Rodgers et al., 1977, Zamarreño et al., 1989), cualstibite (Walenta, 1984), wermlandite (Rius and Allmann, 1984), shigaite (Cooper and Hawthorne, 1996), nikischerite (Huminicki and Hawthorne, 2003)]; $\sqrt{ } 12 \times \sqrt{ } 12$ [mountkeithite (Hudson and Bussell, 1981), quintinite, charmarite and caresite (Chao and Gault, 1997)]; $\sqrt{ } 13 \times \sqrt{ } 13$ [pyroaurite/sjögrenite (Ingram and Taylor, 1967)]; and even $\sqrt{ } 27 \times \sqrt{ } 27$ [karchevskyite (Britvin et al., 2008)]. Offsets of $\sqrt{3} \times \sqrt{ } 3$ layers in some cases result in a lowering of the symmetry to monoclinic and rectangular unit meshes of $\sqrt{ } 3 \times 2$ [hydrocalumite (Sacerdoti and Passaglia, 1988)] or $\sqrt{ } 3 \times 3$ times that of brucite [cyanophyllite (Kolitsch and Giester, 2007; Kolitsch et al., in press); quintinite (Krivovichev et al., 2010b)]. The unit meshes in
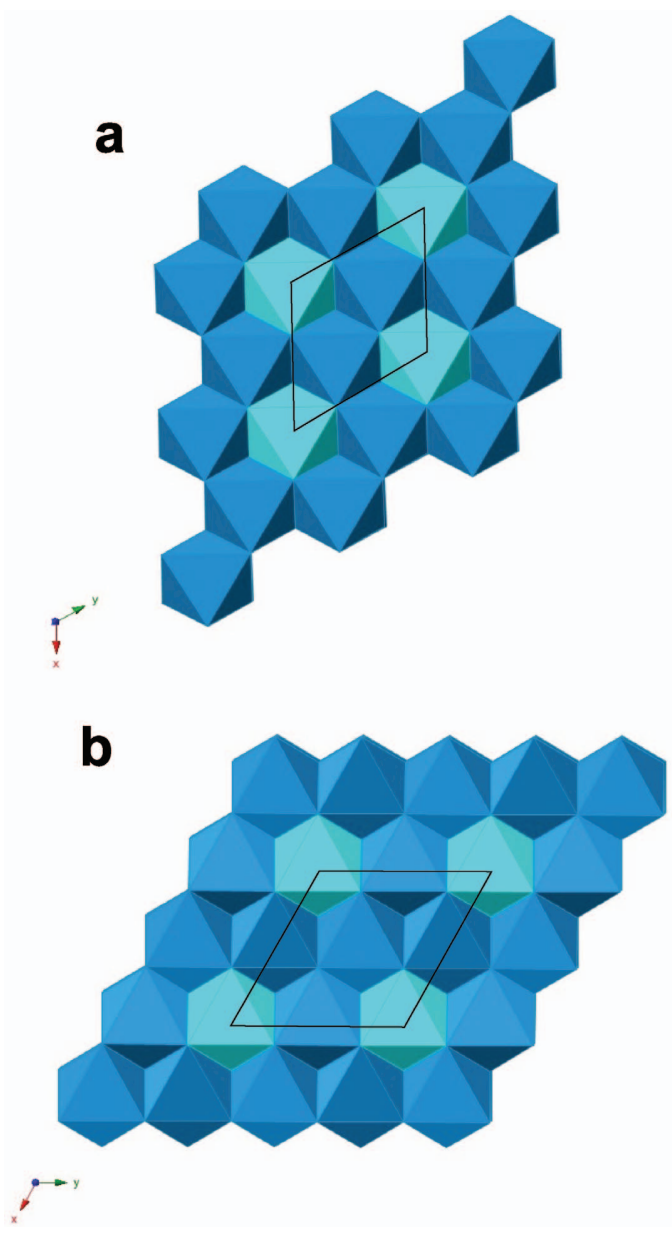

Fig. 3. Most symmetrical ordering patterns of two different types of octahedra in a brucite layer for (a) 2:1 ratio of the two species and (b) 3:1 ratio. In both cases, edge-sharing between two octahedra of the minority species is avoided. 
the $x y$ plane of the known superstructures are shown in Fig. 4. It should be noted that the polytype labelling scheme of Table 1 applies only for stacking of layers with $a \sim 3 \AA(1 \times 1$ mesh); if the true $a$ and $b$ repeats are larger: (1) a much wider range of stacking vectors are possible and (2) the structural significance of a stacking vector such as $[2 / 3,1 / 3,1 / 3]$ may be quite different. For $\sqrt{ } 3 \times \sqrt{ } 3, \quad 3 \times 3, \quad \sqrt{ } 12 \times \sqrt{ } 12$ and $\sqrt{ } 27 \times \sqrt{ } 27$ supercells, this vector will juxtapose a cation or hydroxide sublayer in the ' $A / \alpha$ ' position against another $A / \alpha$, rather than against $B / \beta$ or $C / \gamma$.

The $c$ repeat of the structure can be further modulated by long-range order of octahedral cations. For example, 'quinitinite- $2 \mathrm{H}-3 \mathrm{c}$ ' of Krivovichev et al. (2010a) has an overall formula $\left[\mathrm{Mg}_{4} \mathrm{Al}_{2}(\mathrm{OH})_{12}\right]\left(\mathrm{CO}_{3}\right) \cdot 3 \mathrm{H}_{2} \mathrm{O}$, and a well-defined 6-layer structure, in which the full periodicity along $z$ is determined by factors other than stacking of the brucite layers alone. The unit mesh of one layer contains $\left[\mathrm{Mg}_{2} \mathrm{Al}(\mathrm{OH})_{6}\right]$, with 3 anions per unit mesh in each hydroxide sublayer (Krivovichev et al., 2010a). If $\mathrm{Mg}$ and $\mathrm{Al}$ are not distinguished, the stacking pattern is $2 H_{1}$. However, as the $\mathrm{Mg}$ and $\mathrm{Al}$ are ordered to produce a $3 \times 3$ superstructure in the $x y$ plane, the Al positions are systematically offset so as to triple the repeat. Each charge-balancing interlayer contains $0.5\left(\mathrm{CO}_{3}\right)+1.5\left(\mathrm{H}_{2} \mathrm{O}\right)$, giving a total of 3 oxygens per unit mesh, but the partial occupancies and smearing of electron density in
difference-Fourier maps both imply that the carbonate and water positions are not ordered in these minerals.

Strong positional and orientational ordering of interlayer species is present in some species such as wermlandite and shigaite (which are described in the following text), and this can also lead to increased periodicity along $z$. In these species, it is the offset and orientation of the interlayers that defines the polytypic stacking, rather than that of the octahedral layers. It is also possible for two different types of interlayers to interstratify regularly, as exemplified by coalingite (which is also discussed in the following text).

\section{Minerals with the hydrotalcite structure type}

The members of the hydrotalcite supergroup all have brucite-like structural layers with interlayer anions and water. Some of these minerals contain hydrated cations that are connected to the brucite layers only through hydrogen bonds. Layered calcium aluminate hydrate phases have been included as the hydrocalumite group, although they are anomalous in that the $\mathrm{Ca}$ of the layer makes a seventh bond to an 'interlayer' water. Phases in which hydroxides of the brucite layer are replaced by halides or by the oxygen atoms of complex anions such as sulfate are excluded; these include minerals such as spangolite, $\mathrm{Cu}_{6} \mathrm{Al}(\mathrm{OH})_{12} \mathrm{Cl}\left(\mathrm{SO}_{4}\right) \cdot 3 \mathrm{H}_{2} \mathrm{O}$ (Hawthorne et al.,

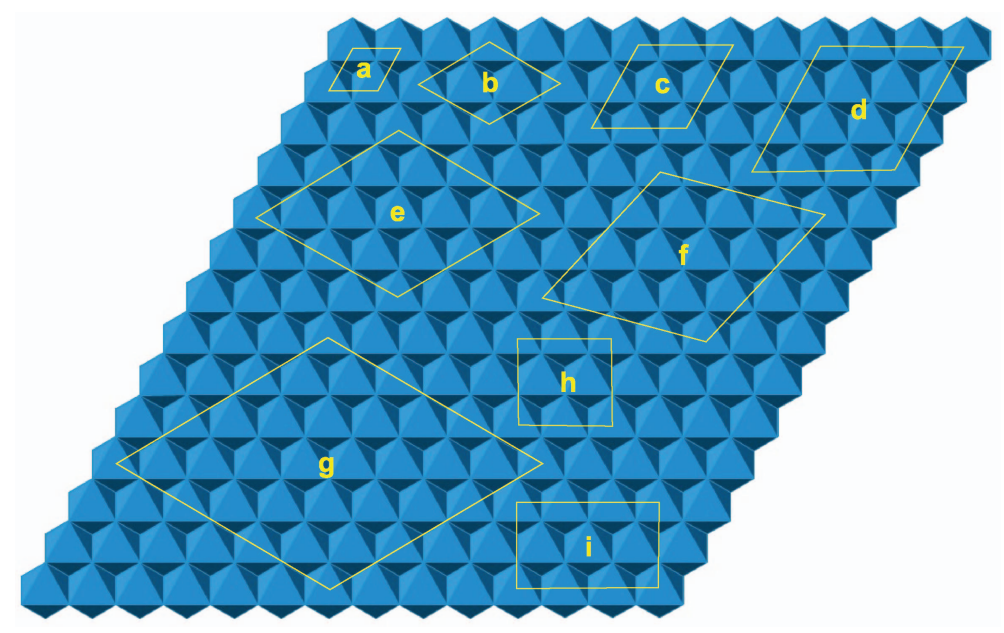

FIG. 4. A brucite-type octahedral layer showing the meshes of the known superstructures in the hydrotalcite supergroup in the $x y$ plane. The (pseudo)hexagonal meshes are $(a) 1 \times 1$ mesh of brucite; (b) $\sqrt{ } 3 \times \sqrt{ } 3 ;(c) 2 \times 2$;

(d) $3 \times 3 ;(e) \sqrt{ } 12 \times \sqrt{ } 12 ;(f) \sqrt{ } 13 \times \sqrt{ } 13 ;(g) \sqrt{ } 27 \times \sqrt{ } 27$. Orthogonal meshes are $(h) \sqrt{ } 3 \times 2 ;(i) \sqrt{ } 3 \times 3$. 
1993). Species with essential vacancies in the layer or with direct linkages through $\mathrm{OH}$ to interlayer cations, as in mooreite, $\mathrm{Mg}_{9} \mathrm{Zn}_{4} \mathrm{Mn}_{2}^{2+}(\mathrm{OH})_{26}\left(\mathrm{SO}_{4}\right)_{2} \cdot 8 \mathrm{H}_{2} \mathrm{O}$ (Hill, 1980) are also excluded. Similarly, exclusions apply to minerals with vacancies in the octahedral layers such as chalcoalumite, $\mathrm{CuAl}_{4}(\mathrm{OH})_{12}\left(\mathrm{SO}_{4}\right) \cdot 3 \mathrm{H}_{2} \mathrm{O}$, the $\mathrm{Ni}$ analogue 'nickelaumite', $\mathrm{Zn}$ analogue kyrgyzstanite and probable nitrate analogues mbobomkulite and hydrombobomkulite (Uvarova et al. 2005), and also to alvanite, $\mathrm{ZnAl}_{4}(\mathrm{OH})_{12}\left(\mathrm{VO}_{3}\right)_{2} \cdot 2 \mathrm{H}_{2} \mathrm{O}$, and its $\mathrm{Ni}$ analogue ankinovichite, which have inovanadate chains in the interlayers (Pertlik and Dunn, 1990). Cyanotrichite, $\mathrm{Cu}_{4} \mathrm{Al}_{2}(\mathrm{OH})_{12}\left(\mathrm{SO}_{4}\right) \cdot 2 \mathrm{H}_{2} \mathrm{O}$, and related species such as the antimonate camerolaite and the fluoride khaidarkanite, are compositionally similar, but do not possess a continuous edgesharing layer of octahedra (Hager et al., 2009). It is worthwhile noting that the term 'hydrotalcite group' has been applied loosely in the past, so as to include many of these excluded species (cf. Lozano et al., 2012).

\section{Hydrotalcite and manasseite}

Hydrotalcite and manasseite are both ideally $\mathrm{Mg}_{6} \mathrm{Al}_{2}(\mathrm{OH})_{16}\left[\mathrm{CO}_{3}\right] \cdot 4 \mathrm{H}_{2} \mathrm{O}$. Hydrotalcite was the first LDH phase to be discovered (Hochstetter, 1842) as contorted, lamellar-to-fibrous white masses of waxy or pearly lustre in serpentinite from Snarum, Norway. It should be noted, however, that Hochstetter regarded the $\mathrm{CO}_{2}$ content in his analyses as due to alteration. The early history of hydrotalcite is convoluted, as is that of the related minerals described below; it is well reviewed by Frondel (1941). Various occurrences were described under synonyms such as 'voelknerite' or 'houghite', and some authors believed hydrotalcite to be a mixture. Hydrotalcite became generally accepted as a valid species only after the optical, thermal and analytical characterization study of Manasse (1915), who derived the currently accepted formula, which was later confirmed by Foshag (1920).

Frondel (1941) performed an X-ray study on hydrotalcite from the type locality and three other occurrences, and found that all contained a mixture of hexagonal and rhombohedral phases, except for the hydrotalcite from Somerville, New York, which was exclusively rhombohedral. The rhombohedral phase gave patterns corresponding to a unit cell with $a=3.065$ and $c=23.07 \AA$, similar to those of pyroaurite and stichtite, whereas the hexagonal phase had $a=3.06$ and $c=15.34 \AA$, similar to those of sjögrenite and barbertonite. The name manasseite was proposed for the hexagonal phase, hydrotalcite being reserved for the rhombohedral phase, and this usage has persisted. The $c$ parameters correspond to 3 brucite layers ( $23 \AA$ repeat of hydrotalcite$3 R)$ and 2 layers $(15 \AA$ repeat of manasseite- $2 H$ ) per unit cell, respectively. It has been known, however, since the study of Ingram and Taylor (1967), that the two minerals are polytypic modifications. Pausch et al. (1986) noted that they commonly intergrow to form compound crystals, with manasseite ( $2 \mathrm{H}$ polytype) at the core and hydrotalcite ( $3 R$ polytype) at the rim. The stacking sequences were verified as $2 H_{1}$ and $3 R_{1}$ by Bookin et al. (1993a).

As the $a$ parameters listed above are approximately the same as that of brucite, these minerals have no long-range ordering of $\mathrm{Mg}$ and $\mathrm{Al}$, and their unit cells contain 3 or $2\left(M^{2+}+M^{3+}\right)$ and $3 / 8$ or $1 / 4\left[\mathrm{CO}_{3}\right]^{2-}$, respectively. Such fractional unitcell contents are unusual for phases of apparently fixed stoichiometry. It is perhaps not surprising that Allman and Jepsen (1969) reported a $R \overline{3} m$ cell with doubled $a$ and $c$ parameters $(a=6.13, c$ $=46.15 \AA$ and $Z=3$ ) for hydrotalcite.

Analyses of 'hydrotalcite' from the type locality with $\mathrm{Mg}: \mathrm{Al}=2: 1$ and 2.30:1 (Stanimirova, 2001) suggest that quintinite may also be present (as discussed in the following text) as well as intergrowths of the two phases.

\section{Pyroaurite and sjögrenite}

Pyroaurite was described with analyses from Långban, Värmland, Sweden, by Igelström (1865), however, the essential carbonate content and correct formula $\mathrm{Mg}_{6} \mathrm{Fe}_{2}^{3+}(\mathrm{OH})_{16}\left[\mathrm{CO}_{3}\right] \cdot 4 \mathrm{H}_{2} \mathrm{O}$, were not confirmed until the study of Manasse (1915). The morphological crystallographic studies of Sjögren (1894) and Flink (1901) suggested rhombohedral symmetry for at least some of the golden-brown platy hexagonal material. The type material was found to contain coexisting hexagonal and rhombohedral phases in the X-ray study of Aminoff and Broomé (1931). These phases had cell parameters of $a=3.097$ and $c=15.56 \AA$; and $a=3.089$ and $c=23.23 \AA$, respectively. Frondel (1941) reserved the name pyroaurite for the rhombohedral phase, and proposed sjögrenite for the hexagonal phase. Allmann (1968) noted that as with the Al analogues hydrotalcite and manasseite, these 
polytypes can occur in a single crystal, with the higher temperature $2 \mathrm{H}$ phase at the core and the $3 R$ phase at the rim. The stacking sequences were verified as $2 H_{1}$ and $3 R_{1}$ by Bookin et al. (1993a).

As is the case for hydrotalcite/manasseite, the unit cells may represent substructures. Ingram and Taylor (1967) reported a cell with $a=6.19$ and $c=46.54 \AA$, with $Z=3$ in $R \overline{3} m$ for pyroaurite, although their cell for sjögrenite $(a=3.113$ and $c=15.61 \AA$ in $P 6_{3} / \mathrm{mmc}$ ) is similar to that of Frondel (1941). Taylor (1969, 1973) observed diffraction corresponding to $\sqrt{ } 3 \times \sqrt{ } 3$ and $\sqrt{ } 13 \times \sqrt{ } 13 x y$ superstructures in pyroaurite and sjögrenite.

The mineral 'igelströmite' was reported from Haaf Grunay, Shetland, Scotland by Heddle (1879) as the hydroxide analogue of pyroaurite. However, re-examination of material from the 'type locality' by Rouxhet and Taylor (1969) showed that although some interlayer $\mathrm{OH}^{-}$ replaced $\left[\mathrm{CO}_{3}\right]^{2-}$, carbonate was dominant. However, they did not discount the possibility that a hydroxide-dominant phase might exist.

\section{Stichtite and barbertonite}

Stichtite was described as massive to fibrous material of a strong lilac colour, associated with serpentine minerals and chromite, from Dundas, Tasmania, Australia, by Petterd (1910: pp. 167-169). Foshag (1920) was the first to suggest the formula $\mathrm{Mg}_{6} \mathrm{Cr}_{2}^{3+}(\mathrm{OH})_{16}\left[\mathrm{CO}_{3}\right] \cdot 4 \mathrm{H}_{2} \mathrm{O}$, which is analogous to that of hydrotalcite, but the existence of two phases with unit cells similar to those of hydrotalcite and manasseite was not confirmed until the X-ray study of Frondel (1941). The hexagonal phase, which was found in specimens from Dundas and from Barberton, Transvaal, South Africa was named barbertonite by Frondel (1941); it has unit-cell parameters $a=$ 3.085 and $c=15.52 \AA$, whereas rhombohedral stichtite sensu stricto, has $a=3.09$ and $c=$ $23.19 \AA$ A. Mills et al. (2011) refined the structures of both minerals by the Rietveld technique for type barbertonite from the Kaapsehoop asbestos mine, Barberton district, South Africa and stichtite from Stichtite Hill, Dundas, Tasmania. Cell parameters were $a=3.096-3.097, c=15.619-15.627 \AA$, with $Z=1 / 4$; and $a=3.096, c=23.507 \AA$, with $Z=3 / 8$, respectively, and the $2 H-3 R$ polytypic relationship was confirmed. Therefore, both minerals are polytypic varieties of stichtite. A $1 T$ polytype was reported from the Terektinsky ridge, Altai Republic, Russia by Tatarinov et al. (1985) and mentioned by Bookin et al. (1993b). Bookin et al. $(1993 b)$ discussed the transformation of Terektinsky ridge stichtite on exposure to light or $\mathrm{X}$-rays from pink material with the $3 R_{1}$ structure of Bookin and Drits (1993) to green material with $a=$ 5.30 and $c=7.36 \AA$, corresponding to the $1 T$ polytype with a $\sqrt{ } 3 \times \sqrt{3}$ superstructure in the $x y$ plane, and stacking disorder indicated by diffuse $h k 0$ reflections.

\section{Meixnerite}

Meixnerite was described in association with talc from fractures in a serpentinite at YbbsPersenberg, Niederösterreich, Austria by Koritnig and Süsse (1975). The formula, $\mathrm{Mg}_{6} \mathrm{Al}_{2}(\mathrm{OH})_{18} \cdot 4 \mathrm{H}_{2} \mathrm{O}$, is derived from that of hydrotalcite if the $\left[\mathrm{CO}_{3}\right]^{2-}$ group is replaced by $2[\mathrm{OH}]^{-}$. Thus, the hydroxide anion plays two distinct roles in the structure and the formula is better written as $\left[\mathrm{Mg}_{6} \mathrm{Al}_{2}(\mathrm{OH})_{16}\right](\mathrm{OH})_{2} \cdot 4 \mathrm{H}_{2} \mathrm{O}$. Only the $3 R$ polytype has been reported, with space group $R \overline{3} \mathrm{~m}$, and unit-cell parameters $a=$ 3.046, $c=22.93 \AA$, with $Z=3 / 8$.

\section{lowaite}

Iowaite was described by Kohls and Rodda (1967), using material from a borehole core from Sioux County, Iowa. Only a small quantity of material was available, and they reported the formula as $\left[\mathrm{Mg}_{4} \mathrm{Fe}^{3+}(\mathrm{OH})_{8}\right] \mathrm{OCl} \cdot 2-4 \mathrm{H}_{2} \mathrm{O}$. Allmann and Donnay (1969) reviewed the data of Kohls and Rodda (1967) and noted their similarity with those of the pyroaurite group. Braithwaite et al. (1994) re-investigated iowaite from the Palabora open pit mine, South Africa, and concluded that the correct formula was $\left[\mathrm{Mg}_{6} \mathrm{Fe}_{2}^{3+}(\mathrm{OH})_{16}\right] \mathrm{Cl}_{2} \cdot 4 \mathrm{H}_{2} \mathrm{O}$, indicating that iowaite is the $\mathrm{Fe}^{3+}$ analogue of woodallite and the $\mathrm{Cl}$ analogue of pyroaurite/sjögrenite. Crystal structure analyses reported by Braithwaite et al. (1994) gave a cell with the space group $R \overline{3} m$, and the parameters $a=3.1183$ and $c=24.113 \AA$, with $Z=3 / 8$, indicating the $3 R$ polytype.

\section{Droninoite}

Droninoite, was described by Chukanov et al. (2009) as the Ni analogue of iowaite and reevesite from the Dronino meteorite (Dronino, Kasimov district, Ryazan Oblast', Russia). The mineral forms dark green to brown fine-grained crusts, with individual crystals less than a micrometre 
across. The empirical formula, based on $Z=6$ is $\mathrm{Ni}_{2.16} \mathrm{Fe}_{0.75}^{2+} \mathrm{Fe}_{0.97}^{3+} \mathrm{Cl}_{1.62}(\mathrm{OH})_{7.10} \cdot 2.28 \mathrm{H}_{2} \mathrm{O}$, which corresponds to an ideal formula $\left[\mathrm{Ni}_{6} \mathrm{Fe}_{2}^{3+}(\mathrm{OH})_{16}\right] \mathrm{Cl}_{2} \cdot 4 \mathrm{H}_{2} \mathrm{O}$, grouping $\mathrm{Ni}$ and $\mathrm{Fe}^{2+}$. Chukanov et al. (2009) gave the lattice type as trigonal $R$, with unit-cell parameters $a=$ 6.206 and $c=46.184 \AA$ A; i.e. a $\sqrt{ } 13 \times \sqrt{ } 13 x y$ supercell and $6 R$ stacking sequence. Based on the unit cell for pyroaurite given by Ingram and Taylor (1967), droninoite is likely to crystallize in the space group $R \overline{3} \mathrm{~m}$. It is noteworthy that IR spectroscopy showed the complete absence of carbonate and sulfate in the structure.

\section{Woodallite}

Woodallite, the $\mathrm{Cl}$ analogue of stichtite/barbertonite, was described by Grguric et al. (2001) from the Mount Keith nickel mine, which is also the type locality for mountkeithite. Woodallite forms lilac masses of platelets $<100 \mu \mathrm{m}$ across which are visually similar to stichtite and mountkeithite. The ideal formula, $\left[\mathrm{Mg}_{6} \mathrm{Cr}_{2}(\mathrm{OH})_{16}\right] \mathrm{Cl}_{2} \cdot 4 \mathrm{H}_{2} \mathrm{O}$, is consistent with other $\mathrm{Cl}$-rich members of the hydrotalcite supergroup, and the space group and unit cell are $R \overline{3} m$ and $a=3.102, c=24.111 \AA$, with $Z=3 / 8$, indicating the $3 R$ polytype.

At Mount Keith, a complete solid-solution series was shown to exist between woodallite and stichtite (e.g. Woodhouse, 2006; Mills et al., $2012 c$ ), and Rietveld analysis was employed to model the $3 R$ structure at various points in the series (Whitfield et al., 2010; Mills et al., 2012c).

\section{Desautelsite}

Desautelsite, $\mathrm{Mg}_{6} \mathrm{Mn}_{2}^{3+}(\mathrm{OH})_{16}\left[\mathrm{CO}_{3}\right] \cdot 4 \mathrm{H}_{2} \mathrm{O}$, is the $\mathrm{Mn}^{3+}$ analogue of hydrotalcite. It has been reported from several localities in the USA (Dunn et al., 1979) and in Japan (Matsubara et al., 1984), as bright orange hexagonal crystals. The space group and unit-cell parameters are $R \overline{3} m$, and $a=3.114, c=24.39 \mathrm{~A}$, with $Z=3 / 8$, indicating the $3 R$ polytype. No superstructure reflections were observed, implying no long-range order in the structure. Experiments (e.g. Hansen and Taylor, 1991) show that desautelsite forms at low temperatures $\left(\sim 35^{\circ} \mathrm{C}\right)$, in slightly alkaline ( $\mathrm{pH} \sim 9$ ) solutions.

\section{Takovite}

Takovite was first described by Maksimović (1957) as $\mathrm{Ni}_{5} \mathrm{Al}_{4} \mathrm{O}_{2}(\mathrm{OH})_{18} \cdot 4 \mathrm{H}_{2} \mathrm{O}$, from Takovo,
Serbia; its properties and genesis were described in further papers (Maksimović, 1958, 1959). As takovite was originally reported to be carbonatedeficient, and in view of its similarities with $\mathrm{LDH}$ phases, Bish and Brindley (1977) investigated samples from Serbia, Australia and France. In these samples $\mathrm{CO}_{3}$ was found to range from 0.80 to 0.95 a.p.f.u. Cation $M^{2+}: M^{3+}$ ratios of 5.87:2.12 and 5.73:2.28 were reported leading to the ideal formula $\mathrm{Ni}_{6} \mathrm{Al}_{2}^{3+}(\mathrm{OH})_{16}\left[\mathrm{CO}_{3}\right] \cdot 4 \mathrm{H}_{2} \mathrm{O}$, which is consistent with a hydrotalcite-group mineral.

Bish and Brindley (1977) reported a rhombohedral unit cell with parameters $a=3.0250$ and $c=$ $22.595 \AA$, which is consistent with the $3 R$ polytype, and Bookin et al. (1993a) verified the $3 R_{1}$ stacking sequence. Mills et al. (2012c) confirmed the $R \overline{3} \mathrm{~m}$ space group with unit-cell parameters $a=3.0290(2)$ and $c=22.5995(15) \AA$, on crystals from the Agoudal mine, Bou Azzer, Tazenakht, Morocco.

Bish (1980) exchanged the interlayer carbonate of takovite with sulfate to produce the $\mathrm{Al}$ analogue of honessite with $c=26.74=3 \times 8.91 \AA$ and carrboydite with $c=32.47-32.50=$ $3 \times 10.82-10.83 \AA$ A. Bookin et al. (1993a) deduced the $3 R_{1}$ stacking sequence for carrboydite, and reported the unusual $3 R_{2}$ structure for the $\mathrm{Al}$ analogue of honessite. Their work implies that anion exchange in the interlayer can cause displacement of the brucite layers and a concomitant change in the polytype.

\section{Reevesite}

Reevesite was described by White et al. (1967) as fine-grained bright yellow cavity infillings in meteorites from Wolf Creek, Western Australia. They noted a strong resemblance between its X-ray powder data and those of pyroaurite, and from qualitative chemical analysis deduced that it must be the $\mathrm{Ni}^{2+}$ analogue, ideally $\mathrm{Ni}_{6} \mathrm{Fe}_{2}^{3+}(\mathrm{OH})_{16}$ $\left(\mathrm{CO}_{3}\right) \cdot 4 \mathrm{H}_{2} \mathrm{O}$. They estimated the unit-cell parameters as $a=6.15$ and $c=45.61 \AA$. A more detailed description was published by De Waal and Viljoen (1971) from material that formed minute greenish yellow hexagonal platelets in nickel ore in the Bon Accord area of the Barberton Mountain Land, South Africa. They gave its formula as $\left(\mathrm{Ni}_{16.69} \mathrm{Fe}_{0.83}^{2+} \mathrm{Mg}_{0.41} \mathrm{Co}_{0.07}\right)$ $\mathrm{Fe}_{6.00}^{3+}(\mathrm{OH})_{48}\left(\mathrm{CO}_{3}\right)_{3} \cdot 12 \mathrm{H}_{2} \mathrm{O}$, which is in accord with the ideal endmember formula suggested by White et al. (1967). The unit cell parameters are $a=6.164$ and $c=45.54 \AA$. The data from both of these sets of authors suggest a 6-layer polytype 
with a $2 \times 2$ superlattice in the $x y$ plane. However, the diffraction data of De Wall and Viljoen (1971) were reinterpreted by Bookin et al. (1993b) as corresponding to an intergrowth of a $3 R_{1}$ structure with $a=3.082$ and $c=22.770 \AA$ and a $1 T$ structure with a $\sqrt{ } 3 \times \sqrt{ } 3$ superstructure in the $x y$ plane, with a somewhat contracted layer spacing of $a=5.337$ and $c=21.608 \AA$.

\section{Jamborite}

Morandi and Dalrio (1973) described jamborite as green fibrous-lamellar pseudomorphs after millerite from ophiolites at $\mathrm{Ca}$ ' dei Ladri and Monteacuto Ragazza near Bologna and Castelluccio di Moscheda near Modena, Italy. The X-ray powder patterns indicated a hexagonal cell (more probably rhombohedral in actuality) with $a=3.07$ and $c=23.3 \AA$. Nickel was the dominant cation, and small but consistent amounts of $\mathrm{Co}$ and $\mathrm{Fe}$ were present. The $\mathrm{S}$ content was consistently found to be $3.5 \mathrm{wt} . \%$, but this was not thought to be due to interlayer sulfate as dissolution in $\mathrm{HCl}$ did not give a precipitate with a $\mathrm{BaCl}_{2}$ solution. The $\mathrm{S}$ was therefore reported to be present as interlayer sulfide anions, which is unique amongst the LDH minerals. There is about one sulfide ion per $7-8$ octahedral cations. The general formula of Morandi and Dalrio, amended to include $\mathrm{Co}^{3+}$, is $\left[(\mathrm{Ni}, \mathrm{Co}, \mathrm{Fe})_{1-x}^{2+}(\mathrm{Ni}, \mathrm{Co}, \mathrm{Fe})_{x}^{3+}(\mathrm{OH})_{2}\right]\left[(\mathrm{OH})_{2}, \mathrm{~S}_{x / 2}\right]$ $\cdot 1-{ }^{x} /{ }_{2} \mathrm{H}_{2} \mathrm{O}$. If we assume that $\mathrm{Co}$ and $\mathrm{Fe}$ are fully oxidized, the analytical data are consistent with the formula $\left[\left(\mathrm{Ni}_{0.94-x}^{2+} \mathrm{Ni}^{3+}{ }_{x} \mathrm{Co}_{0.04}^{3+} \mathrm{Fe}_{0.02}^{3+}\right)\right.$ $\left.(\mathrm{OH})_{2}\right] \mathrm{S}_{0.14}(\mathrm{OH})_{x-0.22} \cdot y \mathrm{H}_{2} \mathrm{O}$, in which $y \sim 1$. Note that $x$ must be $\geqslant 0.22$. At the minimum value of $x, 0.28$ of the octahedral cations are trivalent, which is close to the ideal hydrotalcite ratio of $1 / 4$, and $\mathrm{S}^{2-} \gg \mathrm{OH}^{-}$. It is tempting to speculate that the ideal endmember formula might be $\left[\left(\mathrm{Ni}_{6}^{2+} \mathrm{Ni}_{2}^{3+}\right)(\mathrm{OH})_{16}\right] \mathrm{S}^{2-} \cdot 4 \mathrm{H}_{2} \mathrm{O}$, but at the same time it must be noted that the coexistence of oxidized $\mathrm{Ni}^{3+}$ and reduced $\mathrm{S}^{2-}$ in an oxycompound is unusual, and that the pale green colour of jamborite is not consistent with charge transfer between $\mathrm{Ni}^{2+}$ and $\mathrm{Ni}^{3+}$.

\section{Quintinite}

Quintinite was initially described from Mont Saint-Hilaire, Québec, Canada, as a $3 T$ polytype of $\mathrm{Mg}_{4} \mathrm{Al}_{2}(\mathrm{OH})_{12}\left[\mathrm{CO}_{3}\right] \cdot 3 \mathrm{H}_{2} \mathrm{O}$, by Chao and Gault (1997). The space group given was $P 3_{1} 12$, with unit-cell parameters $a=10.751$ and $c=22.71 \AA$, and $Z=6$. Although the $c$ parameter is similar to that of hydrotalcite, the $a$ repeat is about $\sqrt{ } 12$ times that of brucite, implying the existence of long-range order within the layers. The $\mathrm{Mg}: \mathrm{Al}$ ratio is higher than that of hydrotalcite, as $\mathrm{Al}$ occupies $1 / 3$ of the octahedral sites rather than $1 / 4$. The carbonate content is correspondingly higher (one $\left[\mathrm{CO}_{3}\right]^{2-}$ per 6 octahedra, rather than one per 8 octahedra), but the water content is effectively the same as that of hydrotalcite (one $\mathrm{H}_{2} \mathrm{O}$ per two octahedra). Chao and Gault (1997) also reexamined a well-crystallized gemmy yellow mineral occurring in cavities in dolomite from the Jacupiranga carbonatite, Brazil, originally reported as manasseite by Menezes and Martins (1984), and found it to be a $2 H$ polytype of quintinite, with space group $P 6_{3} 22$ and unit-cell parameters $a=10.571$ and $c=15.171 \AA$, with $Z=$ 4. Chao and Gault (1997) reported several other instances in which phases with a quintinite-like composition had been wrongly described as either hydrotalcite or manasseite. The $3 T$ and $2 H$ polytypes were initially described as distinct mineral species and were assigned separate IMA proposal numbers; they are now regarded as polytypes of a single species.

Arakcheeva et al. (1996) had previously examined the $2 \mathrm{H}$ polytype from Jacupiranga without describing it as a new mineral; however, they reported a different space group $(P \overline{6} 2 m)$ and unit-cell parameters $a=5.283$ and $c=15.150 \AA$, with $Z=1$. Nevertheless, they described strong long-range order of $\mathrm{Mg}$ and $\mathrm{Al}$ within the brucite layers.

Recently, quintinite from the Kovdor alkaline massif, Kola peninsula, Russia, was examined by Krivovichev et al. $(2010 a, b, c)$. Their singlecrystal X-ray study confirmed that quintinite occurs in several structural varieties, with different stacking sequences and different degrees of long-range order. They published structure solutions for three new varieties of quintinite. One is related to the structure of Arakcheeva et al. (1996), but has the repeat in the $c$ direction tripled due to $[2 / 3,1 / 3,0]$ layer displacements every second layer. Thus, the data for quintinite are space group $R 32$, with unit-cell parameters $a=5.275$ and $c=45.36 \AA$, and $Z=3$ (Krivovichev et al., 2010a). The authors proposed the designation 'quintinite- $2 H-3 c$ ' for this modification, to indicate that the stacking of the brucite layers is $2 \mathrm{H}$ if $\mathrm{Mg}-\mathrm{Al}$ order is ignored, but that said, ordering introduces an additional tripling of c. A disadvantage of the notation proposed by 
Krivovichev et al. (2010a) is that it does not make explicit the $R$ lattice of the overall structure. There is a strong $c=15.12 \AA$ subcell, and reflections with $l \neq 3 n$ are weak and diffusely streaked, implying substantial stacking disorder. Their second quintinite variant (Krivovichev et $a l ., 2010 b$ ) displayed monoclinic symmetry for the first time in natural LDH phases other than those of the cualstibite and hydrocalumite groups. They reported the space group as $C 2 / m$, with the unit-cell dimensions $a=5.266, b=9.114$ (which is $\sim \sqrt{3} a), c=7.766 \AA$ and $\beta=103.17^{\circ}$, with $Z=1$, giving $c \sin \beta=7.562 \AA$ and $-c \cos \beta=1.769 \AA$ = $a / 3$. Again, reflections due to $\mathrm{Mg}-\mathrm{Al}$ order within layers were weak and diffuse. In the structure, all layers are equivalent, and the structure is a cationordered superstructure of the conventional $3 R$ polytype. The third quintinite variant (Krivovichev et al., 2010c) was disordered quinitinite- $2 \mathrm{H}$, with the space group $\mathrm{P}_{3} / \mathrm{mmc}$ (corrected from $P 6_{3} / \mathrm{mcm}$ as published) and unitcell parameters $a=3.045$ and $c=15.12-15.18 \AA$, with $Z=1 / 9$. Note that cation ordering may or may not be preserved within a layer; however, it is certain that registration between layers is absent in this phase.

\section{Charmarite and caresite}

Charmarite, $\mathrm{Mn}_{4} \mathrm{Al}_{2}(\mathrm{OH})_{12}\left[\mathrm{CO}_{3}\right] \cdot 3 \mathrm{H}_{2} \mathrm{O}$, and caresite, $\mathrm{Fe}_{4} \mathrm{Al}_{2}(\mathrm{OH})_{12}\left[\mathrm{CO}_{3}\right] \cdot 3 \mathrm{H}_{2} \mathrm{O}$, are the $\mathrm{Mn}^{2+}$ and $\mathrm{Fe}^{2+}$ analogues of quintinite, respectively. They were described along with quintinite by Chao and Gault (1997) from Mont Saint-Hilaire. Charmarite occurs as $2 \mathrm{H}$ and $3 \mathrm{~T}$ polytypes, with the following space groups and unit-cell data: $P 6_{3} 22, a=10.985$ and $c=15.10 \AA$, with $Z=4(2 H)$; and $P 3_{1} 12, a=$ 10.985 and $c=22.63 \AA$, with $Z=6(3 T)$. As with quintinite, the $3 T$ and $2 H$ polytypes were initially described as distinct mineral species and were assigned separate IMA proposal numbers, but they are now considered to be polytypes of a single species. Caresite is known only as the $3 T$ polytype, with the space group $P 3_{1} 12$ and unitcell parameters $a=10.805$ and $c=22.48 \AA$, with $Z=6$.

\section{Zaccagnaite}

Zaccagnaite, ideally $\mathrm{Zn}_{4} \mathrm{Al}_{2}(\mathrm{OH})_{12}\left[\mathrm{CO}_{3}\right] \cdot 3 \mathrm{H}_{2} \mathrm{O}$, the $\mathrm{Zn}$ analogue of quintinite, was described from the Carrara marble of Calagio Quarry, Tuscany, Italy, by Merlino and Orlandi (2001). The space group and unit-cell parameters correspond to the disordered $2 H$ polytype, with the space group $P 6_{3} / m m c$ and unit-cell parameters $a=3.073$ and $c=15.114 \AA$, with $Z=1 / 9$. Diffuse streaks parallel to $\mathbf{c}^{*}$ were observed at $(1 / 3,1 / 3, l)^{*}$ and equivalent loci, and interpreted to imply strong $\mathrm{Zn}-\mathrm{Al}$ ordering in two dimensions, albeit with no interlayer correlation. Witzke and Raade (2000) noted that a second occurrence of zaccagnaite, from Lavrion, Greece, occurred as the $3 R$ polytype, but the unit cell was not refined due to intergrowth with related phases. A $3 R$ polytype was described from the El Soplao cave, Cantabria, Spain by Lozano et al. (2012). This material has space group $R \overline{3} m$, and unit-cell parameters $a=3.0662$ and $c=22.6164 \AA$, with a formula $\left(\mathrm{Zn}_{0.593} \mathrm{Fe}_{0.004} \mathrm{Mg}_{0.015} \mathrm{Mn}_{0.008} \mathrm{Al}_{0.380}\right)$ $(\mathrm{OH})_{2} \quad\left(\mathrm{CO}_{3}\right)_{0.19} \cdot 0.19 \mathrm{H}_{2} \mathrm{O}$. Thus, the $M^{2+}: M^{3+}$ ratio is $1.63: 1$ rather than $2.00: 1$, and the high Al content is charge-balanced by a higher than normal carbonate content $(\equiv 1.14$ per $12[\mathrm{OH}])$ in the interlayer. Note that a variable $M^{2+}: M^{3+}$ ratio, with a tendency toward high contents of $M^{3+}$, is a common feature of minerals in the woodwardite and glaucocerinite groups containing the small divalent cations $\mathrm{Zn}^{2+}, \mathrm{Cu}^{2+}$ and $\mathrm{Ni}^{2+}$ (as noted in the following discussion).

\section{Chlormagaluminite}

Chlormagaluminite was described from a magnetite-chlorite skarn in the Kapaevskaya explosion pipe, Irkutsk Oblast', Russia, by Kashaev et al. (1982). Analysis of the type material gave a formula $\left(\mathrm{Mg}_{3.55} \mathrm{Fe}_{0.27}^{2+} \mathrm{Na}_{0.05}\right)_{\Sigma 3.87}$ $\left(\mathrm{Al}_{1.93} \mathrm{Fe}_{0.07}^{3+} \mathrm{Ti}_{0.01}\right)_{\Sigma 2.01}(\mathrm{OH})_{12}\left[\mathrm{CO}_{3}\right]_{0.12} \mathrm{Cl}_{1.48}$ $\cdot 2.42 \mathrm{H}_{2} \mathrm{O}$, which strongly suggests an ideal endmember formula $\mathrm{Mg}_{4} \mathrm{Al}_{2}(\mathrm{OH})_{12} \mathrm{Cl}_{2} \cdot 3 \mathrm{H}_{2} \mathrm{O}$, and hence that chlormagaluminite is, in terms of its composition, the chloride analogue of quintinite. The space group was reported to be $P 6_{3} / \mathrm{mcm}, P 6_{3} \mathrm{~cm}$ or $P \overline{6} \mathrm{c} 2$, with unit-cell parameters $a=5.29$ and $c=15.46 \AA$, and $Z=3 / 4$. These data correspond to the $2 H$ polytype with $\sqrt{ } 3 \times \sqrt{ } 3$ superstructure in $x y$ plane. The mineral was previously reported under the name 'chlormanasseite' by Feoktistov et al. (1978).

\section{Comblainite}

Comblainite was described as turquoise cryptocrystalline crusts from the Shinkolobwe mine, Katanga, Democratic Republic of the Congo, with a formula $\left(\mathrm{Ni}^{2+}{ }_{x} \mathrm{Co}_{1-x}^{3+}\right)(\mathrm{OH})_{2}\left(\mathrm{CO}_{3}\right)_{(1-x) / 2} \cdot y \mathrm{H}_{2} \mathrm{O}$ by Piret and Deliens (1980). The unit cell is 
rhombohedral, and the parameters recalculate to give axes of $a=3.038$ and $c=22.79 \AA$. The two formulae reported by Piret and Deliens (1980) can be recast on the basis of $6\left[M^{2+}+M^{3+}\right]$ as: $\left[\left(\mathrm{Ni}_{4.07}^{2+} \mathrm{Co}_{1.93}^{3+}(\mathrm{OH})_{12}\right]\left(\mathrm{CO}_{3}\right)_{0.88}(\mathrm{OH})_{0.18} \cdot 4.47 \mathrm{H}_{2} \mathrm{O}\right.$ and $\left[\left(\mathrm{Ni}_{4.07}^{2+} \mathrm{Co}_{1.93}^{3+}(\mathrm{OH})_{12}\right]\left(\mathrm{CO}_{3}\right)_{0.68}(\mathrm{OH})_{0.56}\right.$ $\cdot 6.61 \mathrm{H}_{2} \mathrm{O}$. Possession of $R$ translational symmetry for the 3-layer polytype is more typical of the pyroaurite group than the quintinite group; however, the $M^{2+}: M^{3+}$ ratio is consistently $2: 1$ rather than $3: 1$, so comblainite can be considered to be the $\mathrm{Ni}^{2+}-\mathrm{Co}^{3+}$ analogue of quintinite.

\section{Fougèrite}

There is a very special case in the hydrotalcite supergroup where the two cations in the octahedral layer are the same chemical element in different oxidation states, namely $\mathrm{Fe}^{2+}$ and $\mathrm{Fe}^{3+}$ in the mineral fougèrite (and possibly also $\mathrm{Ni}^{2+}$ and $\mathrm{Ni}^{3+}$ in jamborite). Vysostskii (1905) first described the bluish green colour of socalled gleysols from below the water table ('gley' is transliterated from the Russian 'глей' = 'clay'); this colour was attributed by Arden (1950) to a mixed-valence Fe mineral which was described as 'ferrosic hydroxide' with $\mathrm{Fe}^{2+}$ dominant and the formula $\mathrm{Fe}(\mathrm{OH})_{2+x}$ (see also Taylor, 1980; Herbillon, 2006). The phase was never properly characterized because of the low concentration of $\mathrm{Fe}$ that is usually found in waterlogged soils (about 5\%). However, it was possible, using Mössbauer spectroscopy, (an Feoxidation state selective technique) to attribute the $\mathrm{Fe}^{2+}$ content to a chemical compound which is commonly described as 'green rust', because it is an intermediate $\mathrm{Fe}^{2+}-\mathrm{Fe}^{3+}$ compound which forms during the corrosion of $\mathrm{Fe}$-based materials and steels (Génin et al., 1986, 1996, 1998, 2002; Drissi et al., 1995; Trolard et al., 1997, 2007; Refait et al., 2003). Green rust was first identified by Girard and Chaudron (1935). It is an $\mathrm{LDH}$ type compound, with $\mathrm{Fe}^{2+}$ and $\mathrm{Fe}^{3+}$ in the octahedral layer (cf. Simon et al., 2003; Aïssa et al., 2006). The symmetry depends on the shape of the intercalated anion, being $R \overline{3} m$ ( $3 R$ polytype) for a phase described as 'green rust I' with spherical or planar intercalated anions such as $\mathrm{F}^{-}, \mathrm{Cl}^{-}, \mathrm{I}^{-}, \mathrm{CO}_{3}^{2-}, \mathrm{CH}_{3} \mathrm{COO}^{-}$or $\mathrm{C}_{2} \mathrm{O}_{4}^{2-}$; or $P \overline{3} m 1$ (1T polytype) for 'green rust II' with tetrahedral anions such as $\mathrm{SO}_{4}^{2-}$ or $\mathrm{SeO}_{4}^{2-}$ (Bernal et al., 1959). The $3 R$ phases have unitcell dimensions $a=3.17-3.18$ and $c=$ 22.7-22.9 $\AA$ if the intercalated anions are
$\mathrm{CO}_{3}^{2-}$. The intercalated anion in natural material was not initially known, and it took some time before it was shown to be $\mathrm{CO}_{3}^{2-}$. This carbonatebearing material is the most thermodynamically stable green rust phase, and has been produced in the laboratory by bacterial reduction of $\gamma-\mathrm{FeOOH}$ in anoxic conditions similar to those found in aquifers (Ona-Nguema et al., 2002). In nature, the $\mathrm{CO}_{3}^{2-}$ is produced by the oxidation of organic matter as part of a redox couple in which Fe-reducing bacteria reduce $\mathrm{Fe}^{3+}$ in the absence of oxygen (Ruby et al., 2006).

Characterization of the natural material was complicated by the fact that the $\mathrm{Fe}^{3+}$ molar fraction $x=\left(\mathrm{Fe}^{3+} / \mathrm{Fe}_{\text {tot }}\right)$, as determined by Mössbauer spectroscopy, was always found to be greater than 1/3 (e.g. Génin et al., 1998, 2005; Féder et al., 2005; Rodionov et al., 2006). In contrast, synthetic samples produced by coprecipitation always had $x=1 / 4-1 / 3$, as in any other LDH (Génin et al., 2006b; Génin and Ruby, 2008), and compositions such as $\mathrm{Fe}_{6}^{2+} \mathrm{Fe}_{2}^{3+}(\mathrm{OH})_{16}$ $\mathrm{CO}_{3} \cdot 3 \mathrm{H}_{2} \mathrm{O}$ and $\mathrm{Fe}_{4}^{2+} \mathrm{Fe}_{2}^{3+}(\mathrm{OH})_{12} \mathrm{CO}_{3} \cdot 3 \mathrm{H}_{2} \mathrm{O}$ (Génin et al., 2005). This inconsistency was resolved when it was shown that green rust oxidizes by one of two mechanisms. In the most common mechanism the green rust dissolves, with subsequent precipitation of ferric oxyhydroxides such as ferrihydrite, lepidocrocite and finally goethite (Drissi et al., 1995; Benali et al., 2001). The less common mechanism involves oxidation accompanied by in situ deprotonation to produce the compound $\mathrm{Fe}_{6(1-x)}^{2+} \mathrm{Fe}_{6 x}^{3+} \mathrm{O}_{12} \mathrm{H}_{14-6 x} \mathrm{CO}_{3} \cdot 3 \mathrm{H}_{2} \mathrm{O}$, with $x>1 / 3$ and hence some $\mathrm{O}^{2-}$ replacing $\mathrm{OH}^{-}$ in the hydroxide layer (Génin et al. 2005, 2006a). The existence of this phase might be taken to indicate the existence of a continuous solid solution, with $x$ ranging from 0 to 1 . However, studies of the variation of $x$ in synthetic samples with electrode potential $E_{\mathrm{h}}$ and the derived chemical potential indicate that for $x$ values in the range $1 / 3-2 / 3$, the compositions are mixtures of two endmember phases with $x=1 / 3$ and $x=2 / 3$. Furthermore, it was found that for $x$ in the range $2 / 3-1$, the compositions are mixtures of endmember phases with $x=2 / 3$ and $x=1$, and an additional endmember exists at $x=0$ (Ruby et al., 2010). Low-temperature Mössbauer spectroscopy and magnetic susceptibility measurements support this conclusion (Rusch et al., 2008), and show that these four different compounds have distinct magnetic properties arising from long-range ordering of $\mathrm{Fe}^{2+}$ and $\mathrm{Fe}^{3+}$ within the layers. If $x=0$ [i.e. in $\mathrm{Fe}_{6}^{2+}(\mathrm{OH})_{10}\left(\mathrm{H}_{2} \mathrm{O}\right)_{2} \mathrm{CO}_{3} \cdot 3 \mathrm{H}_{2} \mathrm{O}$ ], all of 
the cations are $\mathrm{Fe}^{2+}$; if $x=1 / 3$ [i.e. in $\mathrm{Fe}_{4}^{2+} \mathrm{Fe}_{2}^{3+}$ $\left.(\mathrm{OH})_{12} \mathrm{CO}_{3} \cdot 3 \mathrm{H}_{2} \mathrm{O}\right]$, the $\mathrm{Fe}^{3+}$ cations are all surrounded by six $\mathrm{Fe}^{2+}$ cations in the pattern shown in Fig. $3 a$, to minimize electrostatic repulsion; if $x=2 / 3$ [i.e. in $\mathrm{Fe}_{2}^{2+} \mathrm{Fe}_{4}^{3+} \mathrm{O}_{2}(\mathrm{OH})_{10}$ $\left.\mathrm{CO}_{3} \cdot 3 \mathrm{H}_{2} \mathrm{O}\right]$, the $\mathrm{Fe}^{2+}$ cations are surrounded by six $\mathrm{Fe}^{3+}$ cations; and if $x=1$ [i.e. in $\mathrm{Fe}_{6}^{3+} \mathrm{O}_{4}(\mathrm{OH})_{8}$ $\mathrm{CO}_{3} \cdot 3 \mathrm{H}_{2} \mathrm{O}$ ], all of the cations are $\mathrm{Fe}^{3+}$ (Rusch et al., 2008). This unusual redox flexibility has a major role in determining gleysol properties.

Samples of 'fougèrite' collected from below the permanent water table display experimental average values of $x$ in the range $1 / 3-2 / 3$, which indicates that they contain a mixture of domains with $x=1 / 3$ and $x=2 / 3$, intergrown in a topotactic relationship, with an overall composition derived from the relative proportions of the two phases according to the lever rule (Génin et al., 2012a). Type fougèrite, as described by Trolard et al. (2007), has such a range and therefore contains two distinct mineral species (which are discussed in the following text). Gleys recently found in maritime marshes (Génin et al., 2012b) have $x$ values in the range $2 / 3-1$, indicating that they are a mixture of domains with $x=2 / 3$ and $x=1$ in topotactic intergrowth. The $x=1$ phase corresponds to the new mineral mössbauerite.

\section{Mössbauerite}

Mössbauerite, (IMA2012-049), ideally $\mathrm{Fe}_{6}^{3+} \mathrm{O}_{4}(\mathrm{OH})_{8} \mathrm{CO}_{3} \cdot 3 \mathrm{H}_{2} \mathrm{O}$, is the fully oxidized $\mathrm{Fe}^{3+}$ analogue of the mixed valence $\mathrm{Fe}^{2+}-\mathrm{Fe}^{3+}$ green rust minerals fougèrite (described in the foregoing text; see also Trolard et al., 2007) and trébeurdenite (described in the following text). The type locality is Mont Saint-Michel Bay, France. Mössbauerite crystallizes in space group $R \overline{3} \mathrm{~m}$, and the unit-cell parameters are $a=3.079$ and $c=22.253 \AA$, with $Z=1 / 2$, implying a $3 R$ polytype with no superstructure in the $x y$ plane. Further details of the identification of mössbauerite by Mössbauer spectroscopy are included in the following text (see also the redefinition of fougèrite) and in Génin et al. (2012b).

\section{Woodwardite}

Woodwardite is a grandfathered species from an unknown type locality in Cornwall, UK (Dana, 1892). The formula was given by Palache et al. (1951) as "probably $\left[\mathrm{Cu}_{4} \mathrm{Al}_{2}(\mathrm{OH})_{12}\right]\left(\mathrm{SO}_{4}\right)$ $\cdot 2-4 \mathrm{H}_{2} \mathrm{O}$ ". A sample from Cornwall in the Natural History Museum, London (specimen BM
40035), studied by Nickel (1976), was difficult to analyse due to decomposition under the electron beam, but showed variability in the $\mathrm{Cu}: \mathrm{Al}$ atomic ratio $(1.73-2.03$, with one anomalously low value of 1.21). Weak and diffuse powder X-ray data were obtained, corresponding to a rhombohedral cell with $a=3.00$ and $c=3 \times 9.1=27.3 \AA$ (Raade et al., 1985). Nickel (1976) noted that dehydration occurred readily with increasing temperature, causing a steady decrease in layer spacing from $9.1 \AA$ at room temperature to $8.1 \AA$ at $120^{\circ} \mathrm{C}$. For consistency with more recently described members of the group, such as reevesite, the formula may be better expressed $\left[\mathrm{Cu}_{1-x} \mathrm{Al}_{x}(\mathrm{OH})_{2}\right]\left(\mathrm{SO}_{4}\right)_{x / 2} \cdot n \mathrm{H}_{2} \mathrm{O}$, in which $x=$ $0.33-0.37$ and $n \leqslant 0.5$. The lower water content differentiates this species from hydrowoodwardite.

\section{Zincowoodwardite}

Witzke and Raade (2000) described zincowoodwardite from Naturhistorisches Museum (Vienna) samples H 858 and G 2172, from Lavrion, Greece, which were previously examined by Raade et al. (1985). Witzke and Raade (2000) also reported data from additional natural material from the Hilarion Mine at Lavrion and synthetic samples, initially described in Witzke (1995). They expressed the formula as $\left(\mathrm{Zn}_{1-x} \mathrm{Al}_{x}\right)(\mathrm{OH})_{2}\left(\mathrm{SO}_{4}\right)_{x / 2} \cdot n \mathrm{H}_{2} \mathrm{O}$. Diffraction indicated the existence of two polytypes, $1 T$ and $3 R$, with probable space groups $P \overline{3}$ and $R \overline{3} \mathrm{~m}$, respectively, and cell contents $Z=1$ and $Z=3$. Cell parameters were $a=3.063$ and $c=8.91 \AA$ for $1 T$; and $a=3.065$ and $c=25.42=3 \times 8.47 \AA$ for $3 R$. Raade et al. (1985) had previously reported $a$ $=5.306=\sqrt{ } 3 \times 3.063 \AA$ and $c=26.77 \AA$ for sample H858, suggesting that a $\sqrt{ } 3 \times \sqrt{ } 3$ superstructure can occur in the $x y$ plane. The composition was, however, variable. The ratio $M^{3+} /\left(M^{2+}+M^{3+}\right)$ ranged from $0.32-0.33$ in the $1 T$ polytype, and from $0.35-0.50$ in the $3 R$ polytype. In the natural $3 R$ polytype, some $\mathrm{Zn}$ was reported to be replaced by $\mathrm{Cu}$, with $\mathrm{Cu} /(\mathrm{Zn}+\mathrm{Cu})$ in the range $0.22-0.24$; this ratio ranged from $0-0.47$ in synthetic samples. The analysis reported for material from sample $\mathrm{H} 858$ by Raade et al. (1985) can be recalculated to produce the formula $\left[\left(\mathrm{Zn}_{4.38} \mathrm{Cu}_{0.94} \mathrm{Al}_{2.68}\right)(\mathrm{OH})_{16}\right]$ $\mathrm{Na}_{0.33}\left(\mathrm{SO}_{4}\right)_{1.33}\left(\mathrm{CO}_{3}\right)_{0.56} \cdot 8.98 \mathrm{H}_{2} \mathrm{O}$; the Na content and high water content suggest an admixture with natroglaucocerinite. The best simplified formula is probably $\left[\mathrm{Zn}_{1-x} \mathrm{Al}_{x}(\mathrm{OH})_{2}\right]\left(\mathrm{SO}_{4}\right)_{x / 2} \cdot n \mathrm{H}_{2} \mathrm{O}$, in which $x=0.32-0.50$ and $\mathrm{n}<3 x / 2$. 


\section{Honessite}

Honessite was described as an oxidation product of Ni-Fe sulfides from Linden, Iowa County, Wisconsin, USA, by Heyl et al. (1959). Bish (1980), studying anion exchange in LDH phases, concluded that honessite was $\left[\mathrm{Ni}_{6} \mathrm{Fe}_{2}^{3+}(\mathrm{OH})_{16}\right]\left(\mathrm{SO}_{4}\right) \cdot 4 \mathrm{H}_{2} \mathrm{O}$, and therefore the sulfate analogue of reevesite. Additional data was reported by Bish and Livingstone (1981), who reported a rhombohedral cell with $a=3.083$ and $c=3 \times 8.90=25.8 \AA$. Bookin et al. $(1993 a)$ deduced a $3 R_{1}$ stacking sequence from $\mathrm{X}$-ray intensity data. Honessite, and the similar but more hydrous phase hydrohonessite, $\left[\mathrm{Ni}_{6} \mathrm{Fe}_{2}^{3+}(\mathrm{OH})_{16}\right]$ $\left(\mathrm{SO}_{4}\right) \sim 7 \mathrm{H}_{2} \mathrm{O}$, which has a larger interlayer spacing of $\sim 11 \AA$ (see following text), interconvert readily depending on temperature and humidity (Bish, 1980). Given the compositional variability shown by other members of this group, it is safest to assume that the 3:1 Ni:Fe ratio is not fixed, and that the best simplified formula for honessite is probably $\left[\mathrm{Ni}_{1-x} \mathrm{Fe}^{3+}{ }_{x}(\mathrm{OH})_{2}\right]\left(\mathrm{SO}_{4}\right)_{x / 2}$ $\cdot n \mathrm{H}_{2} \mathrm{O}$ in which $x<0.5$ and $n<3 x / 2$.

\section{Glaucocerinite}

Glaucocerinite was originally described as a waxy material of uneven blue colour by Dittler and Koechlin (1932) on specimens in the collection of the Naturhistorisches Museum (Vienna) from Lavrion, Greece. These specimens were reexamined by Raade et al. (1985), who regarded those with catalogue numbers G1377 and G1378 to be the true type material. Powder X-ray diffraction indicated that glaucocerinite coexists with a woodwardite-like mineral on sample G2172, and only the latter mineral was found on samples G2173 and H858. The analyses of Raade et al. (1985) indicated that this woodwardite-like phase was zincowoodwardite, and this was confirmed by Witze and Raade (2000). Historically, there has been much confusion between glaucocerinite- and woodwardite-like phases, as evidenced by the JCPDS card 17-132 for 'woodwardite' from Caernarvonshire, Wales, which has powder data corresponding to a glaucocerinite-like cell and is in fact hydrowoodwardite (Witzke, 1999). The same is true for the Cornish 'woodwardite' of Nickel (1976). The unit-cell data of Raade et al. (1985) for glaucocerinite correspond to a rhombohedral cell with $a=3.057-3.070$ and $c=32.52-32.65 \AA$, although two weak additional lines in one diffraction pattern suggested that the true symmetry may be lower. Raade et al. (1985) calculated a formula based on their own analyses of $\left[(\mathrm{Zn}, \mathrm{Cu})_{4.98} \mathrm{Al}_{3.02}(\mathrm{OH})_{16}\right]\left(\mathrm{SO}_{4}\right)_{1.47}(\mathrm{OH})_{0.08}$ $.9 .10 \mathrm{H}_{2} \mathrm{O}$. Witzke (1999) presented analytical data for a range of natural and synthetic glaucocerinites for comparison with hydrowoodwardite. The $\mathrm{Al} /(\mathrm{Zn}+\mathrm{Cu}+\mathrm{Al})$ ratios were $0.38-0.43$ in natural samples and $0.32-0.50$ in synthetic material and the $\mathrm{Cu} /(\mathrm{Zn}+\mathrm{Cu})$ ratios were $0.26-0.29$ in natural samples and $0.00-0.47$ in synthetic material. Hence, there appears to be a complete solid solution from the $\mathrm{Zn}$ endmember towards the $\mathrm{Cu}$ analogue hydrowoodwardite, and a $M^{3+}$ content ranging from values comparable to those of the quintinite group to $M^{2+}: M^{3+}=1: 1$.

Witzke (1999) noted that the maximum sulfate content that is sterically permissible in glaucocerinite is one sulfate for every three $M$ cations, and that the expanded interlayer accommodates three water molecules per sulfate ion in addition to those that are present in the woodwardite group; these form hydrogen bonds to the apical oxygens of the sulfate tetrahedron. Therefore, the total water content is $n>3 x / 2$. The most general simplified formula for glaucocerinite is thus $\left[\mathrm{Zn}_{1-x} \mathrm{Al}_{x}(\mathrm{OH})_{2}\right]$ $\left(\mathrm{SO}_{4}\right)_{x / 2} \cdot n \mathrm{H}_{2} \mathrm{O}$, in which $x=0.32-0.50$ and $n>$ $3 x / 2$, which is similar to zincowoodwardite, but with a higher water content.

\section{Hydrowoodwardite}

Hydrowoodwardite was described as a porous blue botryoidal coating from the St Briccius mine, Königswalde, Saxony, Germany, by Witzke (1999). Its formula was given as $\left[\mathrm{Cu}_{1-x} \mathrm{Al}_{x}(\mathrm{OH})_{2}\right]\left(\mathrm{SO}_{4}\right)_{x / 2} \cdot n \mathrm{H}_{2} \mathrm{O}$, with $x$ ranging from $0.23-0.62$ in natural samples, and a postulated minimum of $n=3 x / 2$ water molecules. It is worthwhile noting that a value of $x>0.50$ (i.e. $\mathrm{Al}>\mathrm{Cu}$ ) may justify the definition of a new species. Some $\mathrm{Cu}$ was replaced by $\mathrm{Zn}$, the range of $\mathrm{Cu} /(\mathrm{Cu}+\mathrm{Zn})$ being between 0.82 and 1.00 in the analysed natural samples, and $0.54-1.00$ in synthetic material, showing that the solid-solution series to glaucocerinite is complete. Witzke (1999) also stated that the 'woodwardites' from the collection of the National Museum of Wales (specimen number NMW 27.111 GR 443 from Simdde Dylluan and number NMW 27.111 GR 464 from the Ffriddgoch mine) examined by Nickel (1976) and Raade et al. (1985) were hydrowoodwardite. This material gave weak and diffuse diffraction patterns similar to those of JCPDS 17-132, corresponding to a rhombohedral 
cell with $a=3.066$ and $c=3 \times 10.93=32.80 \AA$. The partial analysis of Raade et al. (1985) gave a $\mathrm{Cu}: \mathrm{Zn}: \mathrm{Al}$ cation ratio of 57.0:0.5:42.5 for this sample, so that $\mathrm{Cu} / \mathrm{Al}=1.34$, which contrasts with earlier analyses reported in Nickel (1976), which have $\mathrm{Cu} / \mathrm{Al}$ ratios of $0.62-0.82$. Witzke (1999) noted that hydrowoodwardite dehydrates to woodwardite in dry air over a period of weeks and can be rehydrated by immersion in water.

Witzke (1999) also reported a variety of hydrowoodwardite from the St Christoph mine, Bärenhecke, Germany, with $\left[\mathrm{CO}_{3}\right]^{2-}$ substitution for $\left[\mathrm{SO}_{4}\right]^{2-}$ accompanied by minor uranyl ions, which he presumed to reside in the interlayer, and gave the formula $\left[\mathrm{Cu}_{0.49} \mathrm{Zn}_{0.01} \mathrm{Al}_{0.50}(\mathrm{OH})_{2}\right]$ $\left(\mathrm{SO}_{4}\right)_{1.6}\left(\mathrm{CO}_{3}\right)_{0.09}\left(\mathrm{UO}_{2}\right)_{0.01} \cdot n \mathrm{H}_{2} \mathrm{O}$.

\section{Carrboydite}

Carrboydite was described with a mean formula $(\mathrm{Ni}, \mathrm{Cu})_{6.90} \mathrm{Al}_{4.48}\left(\mathrm{SO}_{4}, \mathrm{CO}_{3}\right)_{2.78}(\mathrm{OH})_{21.69}$ $\cdot 3.67 \mathrm{H}_{2} \mathrm{O}$, from lateritized komatiites at the Carr Boyd Rocks mine, Western Australia, by Nickel and Clarke (1976). The reported Ni:Al ratio ranges between 1.05 and 1.80. Electron microscopy showed carrboydite spherulites to consist of aggregates of thin platy crystals, and an X-ray and electron diffraction study indicated a metrically hexagonal unit cell with $a=9.14$ and $c=10.34 \AA$. A second phase with a larger layer spacing of $\sim 11 \AA$ was intimately associated. This was initially interpreted as a more highly hydrated relative of carrboydite, and was considered to be an unnamed nickel analogue of glaucocerinite by Nickel (1976) and Raade et al. (1985). It has a rhombohedral unit cell with $a=3.022$ and $c=$ $32.45=3 \times 10.82 \AA$.

The mineral with $c=10.34 \AA$ is the $1 T$ polytype of carrboydite. Bookin et al. (1993a) identified the polytype with the 3-layer structure as $3 R_{1}$, which is the same as the synthetic carrboydite of Bish (1980), which was synthesized from takovite by anion exchange.

The $a$ repeat of carrboydite sensu stricto is typical of a $3 \times 3$ superstructure in the $x y$ plane. Nickel and Clarke (1976) explained the unusual $c$ repeat as possibly arising from the presence of a double brucite layer (i.e. and ...XMXMX... sandwich rather than ...XMX...); however, even with occupancy of the octahedral sites reduced to $75 \%$ to obtain the correct stoichiometry, this structure has an implausibly high coordination number for the central layer hydroxide ions. It is more probable that conventional $M X_{2}$ layers are present, and the interlayer spacing increases from $8 \AA$ due to the presence of additional intercalated octahedral cations. Recalculating the formula on the basis of $18(\mathrm{OH})$ gives $\left[(\mathrm{Ni}, \mathrm{Cu})_{5.28} \mathrm{Al}_{3.72}\right.$ $\left.(\mathrm{OH})_{18}\right] \mathrm{Ni}_{0.44}\left(\mathrm{SO}_{4}, \mathrm{CO}_{3}\right)_{2.31} \cdot 3.04 \mathrm{H}_{2} \mathrm{O}$.

Given the reversible hydration and dehydration properties of these minerals, there does not appear to be any justification for making a species-level distinction between carrboydite and the " $11 \AA$ phase'. Disregarding the superstructures in the $x y$ plane and minor changes in the hydration state and $M^{2+}: M^{3+}$ ratio, they can be regarded as the $1 T$ and $3 R$ polytypes of a more broadly defined carrboydite, with a general formula $\left[(\mathrm{Ni}, \mathrm{Cu})_{1-x} \mathrm{Al}_{x}(\mathrm{OH})_{2}\right] \mathrm{Ni}_{y}\left(\mathrm{SO}_{4}, \mathrm{CO}_{3}\right)_{x / 2+y} \cdot n \mathrm{H}_{2} \mathrm{O}$, which can be simplified to $\left[\mathrm{Ni}_{1-x} \mathrm{Al}_{x}(\mathrm{OH})_{2}\right]$ $\left(\mathrm{SO}_{4}\right)_{x / 2} \cdot n \mathrm{H}_{2} \mathrm{O}$, with $x \sim 0.40$ and $n \sim 0.33$. Regardless of the details of its superstructure, polytypic modification and interlayer content, carrboydite is the $\mathrm{Ni}$ analogue of glaucocerinite and the $\mathrm{Al}$ analogue of hydrohonessite.

\section{Hydrohonessite}

Hydrohonessite occurs as microscopic yellow flakes and was originally found in 1971 at Otter Shoot, Kambalda, Western Australia, in amounts that were too small for a full characterization (Nickel and Wildman, 1981). Its nature was finally determined by Nickel and Wildman (1981) by comparison with carrboydite, mountkeithite and motukoreaite. Bish and Livingstone (1981) reported another occurrence of hydrohonessite on the island of Unst, Shetland, Scotland. The hydrohonessite of Nickel and Wildman (1981) was described with a metrically hexagonal cell with $a=3.09$ and $c=10.80 \AA$, indicating the $1 T$ polytype, whereas that of Bish and Livingstone (1981) had $c=33.4=3 \times 11.13 \AA$. An analysis of diffraction intensities led Bookin et al. $(1993 a)$ to suggest the unusual stacking sequence $3 R_{2}$ for this latter polytype. The empirical formula reported by Nickel and Wildman (1981) was $\left[\mathrm{Ni}_{5.43} \mathrm{Fe}_{2.57}^{3+}(\mathrm{OH})_{16}\right]$ $\mathrm{Ni}_{0.98}\left(\mathrm{SO}_{4}\right)_{2.26} \cdot 6.95 \mathrm{H}_{2} \mathrm{O}$, which is close to honessite but with additional water. The excess of octahedral cations over hydroxide indicates the presence of interlayer octahedra, although the excess $\mathrm{Ni}$ in the structure does not appear to be as readily exchangeable as the excess $\mathrm{Mg}$ of mountkeithite (Nickel and Wildman, 1981). The formula given for Unst hydrohonessite by Bish and Livingstone (1981), $\left[\mathrm{Ni}_{5.55} \mathrm{Mg}_{0.10} \mathrm{Fe}_{2.35}^{3+}\right.$ $\left.(\mathrm{OH})_{16}\right]\left(\mathrm{SO}_{4}\right)_{1.18}: x \mathrm{H}_{2} \mathrm{O}$, has less sulfate and no 
interlayer $\mathrm{Ni}$, suggesting either that the intercalated octahedral cation may not be essential or that the nickel content was overestimated by Nickel and Wildman (1981). The expansion of the layer spacing to $\sim 11 \AA$ may be a result of the presence of additional water, additional sulfate, additional octahedral cations of type similar to those of the brucite layers, or some combination of the above. Regardless of these details, hydrohonessite is considered to be the $\mathrm{Fe}^{3+}$ analogue of carrboydite.

\section{Mountkeithite}

Mountkeithite was described as a white flaky alteration product of stichtite from the Mount Keith nickel deposit, $400 \mathrm{~km}$ north-northwest of Kalgoorlie, Western Australia (Hudson and Bussell, 1981). The mineral has intercalated octahedral cations as in the wermlandite group, but a distinctive feature of its chemistry is that these are $\mathrm{Mg}^{2+}$, and constitute an exchangeable $\mathrm{MgSO}_{4}$ component. This component is lost so readily that mountkeithite reacts with water to produce a pyroaurite-like phase with a $7.8 \AA$ layer spacing. This reaction can be fully reversed by immersion in a $1 \mathrm{M} \mathrm{MgSO}_{4}$ solution. The powder data were best fitted by a hexagonal unit cell with $a=10.698$ and $c=22.545 \AA$, corresponding to a $\sqrt{ } 12 \times \sqrt{ } 12$ superstructure in the $x y$ plane, a 2 layer structure with less than full occupancy of the interlayer sites for a formula with $24(\mathrm{OH})$ in the brucite layer, and $Z=2$. The structural formula hypothesized by Hudson and Bussell (1981), with minor omissions, is $\left[\left(\mathrm{Mg}_{8.15} \mathrm{Ni}_{0.85} \mathrm{Cu}_{0.02}\right)\right.$ $\left.\left(\mathrm{Fe}_{1.31}^{3+} \mathrm{Cr}_{1.02} \mathrm{Al}_{0.65}\right)(\mathrm{OH})_{24}\right]\left(\mathrm{Mg}_{1.94} \mathrm{Ni}_{0.18}\right)$ $\left(\mathrm{SO}_{4}\right)_{2.32}\left(\mathrm{CO}_{3}\right)_{1.11} \cdot 9.39 \mathrm{H}_{2} \mathrm{O}$, suggesting an ideal formula close to $\left[\left(\mathrm{Mg}_{9} \mathrm{Fe}_{3}^{3+}\right)(\mathrm{OH})_{24}\right]$ $\mathrm{Mg}_{2}\left(\mathrm{SO}_{4}\right)_{3.5} \cdot 9 \mathrm{H}_{2} \mathrm{O}$. No information about the ordering or interconnection of the interlayer $\mathrm{Mg}^{2+}, \mathrm{SO}_{4}^{2-}$ and $\mathrm{H}_{2} \mathrm{O}$ is currently available. However, regardless of its superstructure, polytypic modifications and exact interlayer composition (particularly the loosely held additional cations), mountkeithite is considered to be the $\mathrm{Mg}$ analogue of hydrohonessite, with a simplified formula $\left[\mathrm{Mg}_{1-x} \mathrm{Fe}^{3+}{ }_{x}(\mathrm{OH})_{2}\right]\left[\mathrm{SO}_{4}\right]_{x / 2} \cdot n \mathrm{H}_{2} \mathrm{O}$, in which $x \sim 0.25$ and $n \sim 3 x$.

\section{Zincaluminite}

Zincaluminite is a grandfathered mineral species that is not described to modern standards and is therefore questionable. It occurs at the Kamariza mine, Lavrion, Greece (Bertrand and Damour, 1881; Palache et al., 1951) as small hexagonal or pseudohexagonal plates. The formula is commonly reported to be $\mathrm{Zn}_{6} \mathrm{Al}_{6}\left[\mathrm{SO}_{4}\right]_{2}$ $(\mathrm{OH})_{26} \cdot 5 \mathrm{H}_{2} \mathrm{O}$, but no structural data are available. The formula can be recast as $\left[\mathrm{Zn}_{3} \mathrm{Al}_{3}(\mathrm{OH})_{12}\right]$ $\left[\mathrm{SO}_{4}\right](\mathrm{OH}) \cdot 2.5 \mathrm{H}_{2} \mathrm{O}$, which suggests a hydrotalcite-like mineral. The $M^{2+}: M^{3+}$ ratio of $1: 1$ is very high in comparison to most $\mathrm{LDH}$ compounds, but has been reported in synthetic $\mathrm{Cu}$-free glaucocerinite (Witzke, 1999), which is almost identical in composition to zincaluminite. The mineral urgently needs further study; it is not obvious that it merits distinction from $\mathrm{Cu}$-free glaucocerinite or zincowoodwardite.

\section{Wermlandite}

Wermlandite is the prototype for a group of LDH minerals which contain both anions and hydrated cations as intercalated species. Wermlandite was described by Moore (1971) as green-grey platy crystals with magnetite and drusy calcite in dolomitic marble from Långban, Värmland, Sweden. The interlayer anion was originally reported to be carbonate, but was later shown to be sulfate by Rius and Allmann (1984) who expressed the formula as $\left[\mathrm{Mg}_{7}\left(\mathrm{Al}_{0.57} \mathrm{Fe}_{0.43}\right)_{2}\right.$ $\left.(\mathrm{OH})_{18}\right]^{2+}\left[\left(\mathrm{Ca}_{0.6} \mathrm{Mg}_{0.4}\right)\left(\mathrm{SO}_{4}\right)_{2}\left(\mathrm{H}_{2} \mathrm{O}\right)_{12}\right]^{2-}$ with half of the $\mathrm{H}_{2} \mathrm{O}$ forming a coordination octahedron around the interlayer $(\mathrm{Ca}, \mathrm{Mg})$ and the remaining $\mathrm{H}_{2} \mathrm{O}$ molecules being hydrogenbonded to this octahedron, the sulfate and the hydroxide layers. The ideal formula is therefore $\left[\mathrm{Mg}_{7} \mathrm{Al}_{2}(\mathrm{OH})_{18}\right]\left[\mathrm{Ca}\left(\mathrm{H}_{2} \mathrm{O}\right)_{6}\right]\left[\mathrm{SO}_{4}\right]_{2} \cdot 6 \mathrm{H}_{2} \mathrm{O}$. The space group and unit-cell parameters are $P \overline{3} \mathrm{c}$, and $a=9.303, c=22.57 \AA$, with $Z=2$, which are consistent with a 2-layer structure. It is important to note that Bookin et al. (1993a) showed that the stacking of the brucite-like layers is actually $1 T$, and the doubling of the period along $z$ arises from orientational ordering of the interlayer sulfate and water groups. This complex but well-ordered interlayer, which contains large species, results in an increase of the layer periodicity in wermlandite to $\sim 11 \AA$; the $3 \times 3$ superstructure in the $x y$ plane allows ordering of the $7 M^{2+}$ and $2 M^{3+}$ in each layer. The wermlandite structure of Rius and Allmann (1984) is shown schematically in Fig. 5. The 7:2 ordering pattern of $\mathrm{Mg}$ and $\mathrm{Al}$ in the octahedral layer is shown in Fig. 6, along with the two differently oriented interlayers of the unit cell, which are related by a $c$-glide. By analogy with 'quintinite- $2 H-3 c$ ' (which is described in the 


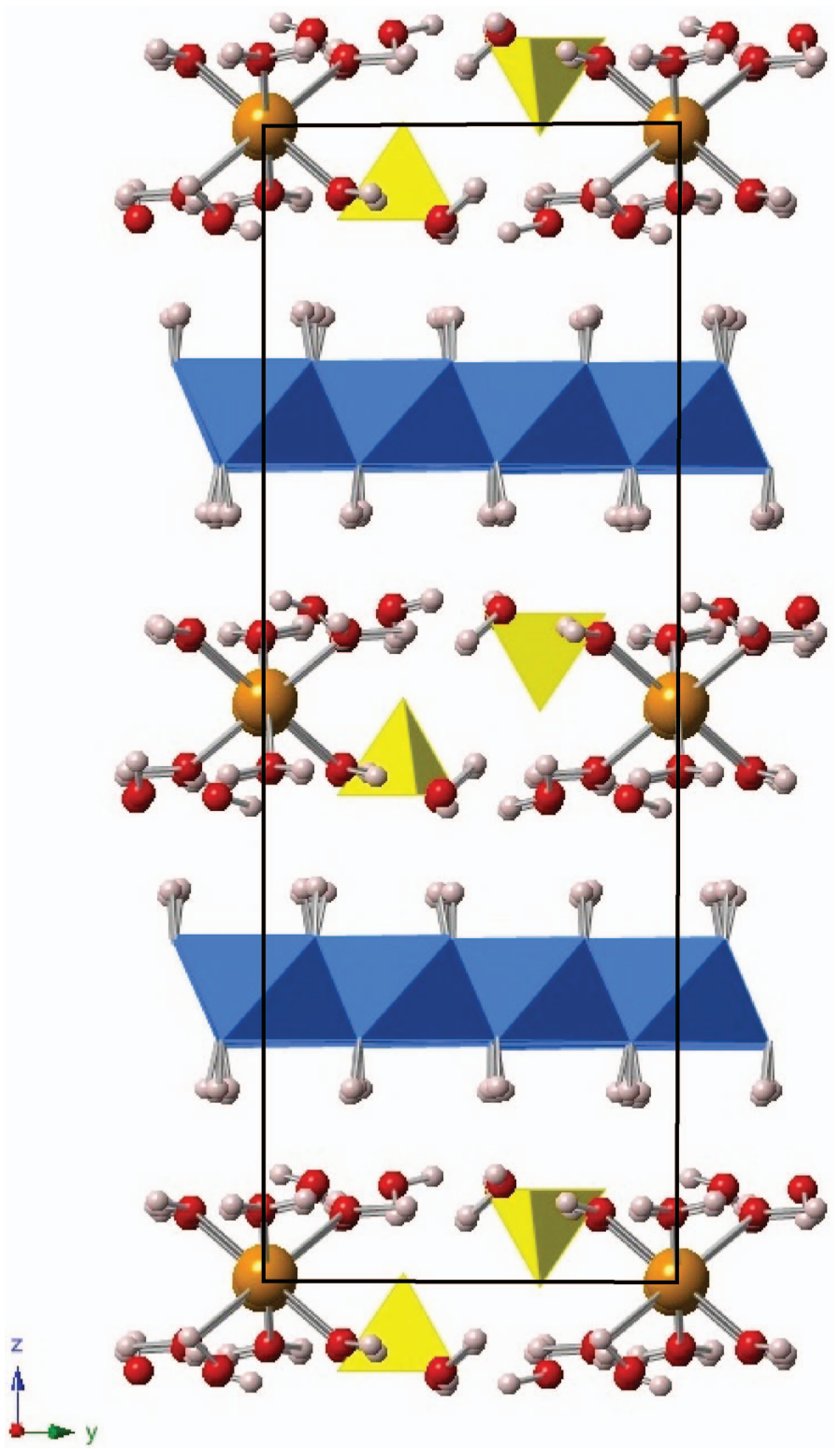

FIG. 5. View of the wermlandite structure down the $x$ axis. The $(\mathrm{Mg}, \mathrm{Al})$ octahedra are blue, interlayer $\left[\mathrm{SO}_{4}\right]^{2-}$ tetrahedra are yellow, $\mathrm{Ca}^{2+}$ are large orange spheres, $\mathrm{H}^{+}$are small pink spheres and the $\mathrm{O}^{2-}$ of $\mathrm{H}_{2} \mathrm{O}$ molecules are medium-sized red spheres. Note that the two octahedral layers are not offset but the sulfate tetrahedra of successive interlayers are differently oriented.

previous text), the wermlandite polytype could be described as 'wermlandite- $1 T-2 c$ ' rather than 'wermlandite- $1 T$ ', to emphasize the fact that the two brucite layers are not oriented differently; however, this notation is problematic and is not adopted herein. For the wermlandite group, the standard polytype symbols proposed by Guinier $e t$ al. (1984) are probably sufficient, but the fact that the structural principle behind the stacking variation differs from that in the groups with simpler interlayers should be borne in mind: it is based on the offset and orientation of the 


\section{HYDROTALCITE SUPERGROUP NOMENCLATURE}
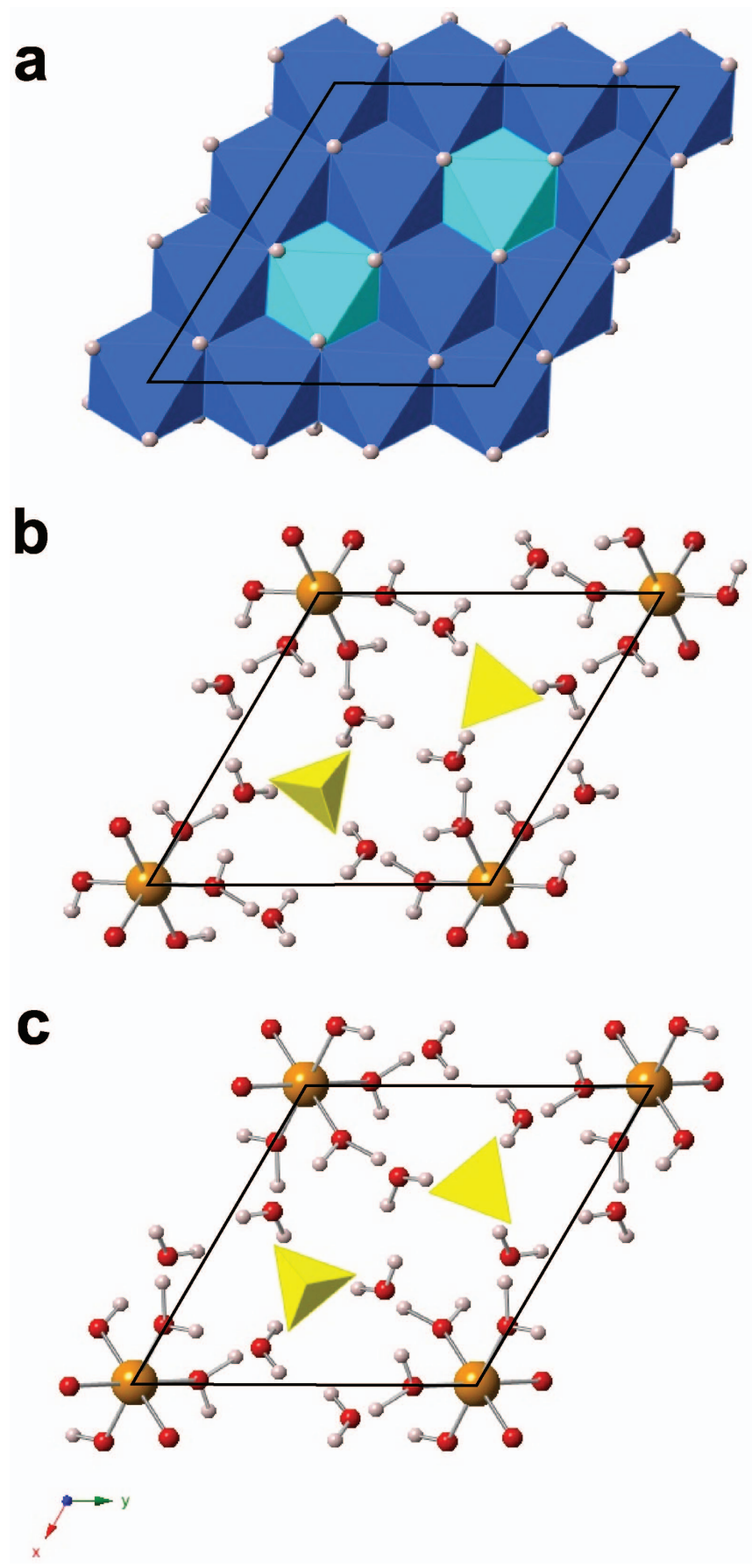

Fig. 6. Slices of the wermlandite structure parallel to (001). (a) The ordering pattern of $7 \mathrm{Mg}$ (dark) and $2 \mathrm{Al}$ (light) octahedra in the brucite layer at $0.1<z<0.4 ;(b)$ the interlayer at $-0.1<z<0.1$, showing $\left[\mathrm{SO}_{4}\right]^{2-}$ tetrahedra, $\left[\mathrm{Ca}\left(\mathrm{H}_{2} \mathrm{O}\right)_{6}\right]^{2+}$ octahedra and additional $\mathrm{H}_{2} \mathrm{O} ;(c)$ the interlayer at $0.4<z<0.6$, reflected relative to that of $(b)$ by a $c$-glide. The $(\mathrm{Mg}, \mathrm{Al})$ octahedra are blue, interlayer $\left[\mathrm{SO}_{4}\right]^{2-}$ tetrahedra are yellow, $\mathrm{Ca}^{2+}$ are large orange spheres, $\mathrm{H}^{+}$ are small pink spheres and the $\mathrm{O}^{2-}$ of $\mathrm{H}_{2} \mathrm{O}$ molecules are medium-sized red spheres. 
interlayer components rather than that of the octahedral layers.

Brindley (1979) and Rius and Allmann (1984) noted that expanded $11 \AA$ layer structures are fragile, and are readily destroyed or converted into more compact layers by ion exchange, mild heating, grinding or dehydration. The resulting intergrowths of phases and their decomposition products may complicate characterizations of minerals in this group.

\section{Shigaite}

Shigaite was described as yellow hexagonal plates from the Ioi mine, Shiga Prefecture, Japan by Peacor et al. (1985) and has subsequently been reported from several other metamorphosed manganese deposits. It has the formula $\left[\mathrm{Mn}_{6} \mathrm{Al}_{3}(\mathrm{OH})_{18}\right]\left[\mathrm{Na}\left(\mathrm{H}_{2} \mathrm{O}\right)_{6}\right]\left[\mathrm{SO}_{4}\right]_{2} \cdot 6 \mathrm{H}_{2} \mathrm{O}$, which is analogous to that of wermlandite, but with a greater proportion of $\mathrm{M}^{3+}$ in the brucite-like sheets and $\mathrm{Na}^{+}$instead of $\mathrm{Ca}^{2+}$ in the interlayer. The structure was refined by Cooper and Hawthorne (1996) using a crystal from the N'Chwaning mine, South Africa. The space group and unit-cell parameters are $R \overline{3}$ and $a=$ 9.512, $c=33.074 \AA$, with $Z=3$. The $3 \times 3$ superstructure in the plane of the layers is similar to that of wermlandite. The $6 M^{2+}$ and $3 M^{3+}$ in each layer are well ordered, with $M^{3+}$ occupying both of the sites in the wermlandite structure and one additional site, and $M^{2+}$ forming a honeycomb net around $M^{3+}$ such that no two $M^{3+}$ octahedra share edges (as shown in Fig. $2 b$ ). The $3 \times 3$ xy unit mesh contains three $\mathrm{Al}$ atoms at vectors $<2 / 3,1 / 3,0>$ relative to one another, so the 3 layer rhombohedral cell cannot be generated by displacements of the brucite sheets. Instead, the 3layer periodicity is defined by shifts of the interlayer $\left[\mathrm{Na}\left(\mathrm{H}_{2} \mathrm{O}\right)_{6}\right]^{+}$and $\left[\mathrm{SO}_{4}\right]^{2-}$ groups. Note that labelling the polytype ' $1 T-3 c$ ' would fail to express the translational symmetry of the rhombohedral lattice, as is also the case for 'quintinite-2H-3c' (as discussed in the foregoing text). However, in common with wermlandite, it should be borne in mind that the standard polytype label ' $3 R$ ' does not have the same stacking implications for shigaite as it does, for example, in minerals of the hydrotalcite group.

\section{Nikischerite}

Nikischerite, $\left[\mathrm{Fe}_{6}^{2+} \mathrm{Al}_{3}(\mathrm{OH})_{18}\right]\left[\mathrm{Na}\left(\mathrm{H}_{2} \mathrm{O}\right)_{6}\right]$ $\left[\mathrm{SO}_{4}\right]_{2} \cdot 6 \mathrm{H}_{2} \mathrm{O}$, is the $\mathrm{Fe}^{2+}$ analogue of shigaite. It was described from the Huanuni tin mine, Dalence Province, Oruro Department, Bolivia by Huminicki et al. (2003) as large euhedral green crystals; the structure was refined by Huminicki and Hawthorne (2003). The space group and unitcell parameters for the $3 R$ polytype are $R \overline{3}$ and $a=$ 9.347, $c=33.000 \AA$, with $Z=3$.

\section{Motukoreaite}

Motukoreaite was described from Motukorea (Brown's Island), Auckland, New Zealand, by Rodgers et al. (1977), as a white, clay-like cement phase in tuffs and beach rocks. Electron microscopy by Brindley (1979), Ramanaidou and Noack (1987) and Bryner et al. (1991) has confirmed a thin platy hexagonal habit at a micrometre scale. Various formulae have been given for the mineral. If the empirical formula of Rodgers et al. (1977) is recalculated to $9 M$, it becomes $\left(\mathrm{Na}_{0.22} \mathrm{~K}_{0.02}\right)_{\Sigma 0.24}\left(\mathrm{Mg}_{5.47} \mathrm{Mn}_{0.10}\right.$ $\left.\mathrm{Zn}_{0.06} \mathrm{Al}_{3.37}\right)_{\Sigma 9.00}(\mathrm{OH})_{15.45}\left[\mathrm{CO}_{3}\right]_{1.88}\left[\mathrm{SO}_{4}\right]_{1.20}$ $\cdot 8.21 \mathrm{H}_{2} \mathrm{O}$, which can be rearranged to approximate a mineral of the wermlandite group as $\left[(\mathrm{Mg}, \mathrm{Mn}, \mathrm{Zn})_{5.63} \mathrm{Al}_{3.37}(\mathrm{OH})_{17.33}\left(\mathrm{H}_{2} \mathrm{O}\right)_{0.67}\right]$ $\left[(\mathrm{Na}, \mathrm{K})_{0.24} \square_{0.76}\left(\mathrm{H}_{2} \mathrm{O}\right)_{6}\right]\left[\mathrm{HCO}_{3}\right]_{1.88}\left[\mathrm{SO}_{4}\right]_{1.20}$ $\cdot 0.63 \mathrm{H}_{2} \mathrm{O}$. Note the extreme deficiency of alkalis and water, and the dominance of (bi)carbonate. The formula $\mathrm{NaMg}_{19} \mathrm{Al}_{12}\left(\mathrm{CO}_{3}\right)_{6.5}\left(\mathrm{SO}_{4}\right)_{4}(\mathrm{OH})_{54}$ $\cdot 28 \mathrm{H}_{2} \mathrm{O}$ used by Bryner et al. (1991) is too low in water to provide a complete hydroxide layer and interlayer cation hydration sphere. The formula of motukoreaite departs from that expected for the wermlandite group due to dehydration and contamination by other phases (Brindley, 1979; Rius and Plana, 1986). Nevertheless, it has been accepted as the $\mathrm{Mg}$ analogue of shigaite and nikischerite (e.g. Rius and Plana, 1986; Huminicki and Hawthorne, 2003). The model formula used by Rius and Plana (1986) for their structure determination was $\left[\mathrm{Mg}_{6} \mathrm{Al}_{3}(\mathrm{OH})_{18}\right]\left[\left(\mathrm{Na}_{0.67} \square_{0.33}\right)\left(\mathrm{H}_{2} \mathrm{O}\right)_{6}\right]$ $\left[\mathrm{SO}_{4}\right]_{1.33} \cdot 6 \mathrm{H}_{2} \mathrm{O}$, which is not charge balanced. Huminicki and Hawthorne (2003), however, used an electrostatically neutral formula which can be rewritten $\left[\mathrm{Mg}_{5.6} \mathrm{Al}_{3.4}(\mathrm{OH})_{18}\right]\left[\left(\mathrm{Na}_{0.6} \square_{0.4}\right)\right.$ $\left.\left(\mathrm{H}_{2} \mathrm{O}\right)_{6}\right]\left[\mathrm{SO}_{4}\right]_{1.3}\left[\mathrm{CO}_{3}\right]_{0.7} \cdot 6 \mathrm{H}_{2} \mathrm{O}$. This suggests the following: (1) there is some variability in the $\mathrm{Mg}: \mathrm{Al}$ ratio; (2) the $\mathrm{Na}$ site is partially occupied, and the occupancy may be more or less than $50 \%$; (3) carbonate (or possibly bicarbonate) or sulfate may predominate as the interlayer anion; and therefore (4) analyses may have been undertaken on more than one phase. 
Structural data show that motukoreaite belongs to the wermlandite group. Rodgers et al. (1977) reported the unit cell to be hexagonal with $a=$ 9.336 and $c=44.72 \AA$. The $c$ repeat suggests that $Z$ should be 4 for this formula unit. According to Zamarreño et al. (1989), motukoreaite is a common alteration product of submarine basaltic glasses. Their X-ray diffraction data suggest space group $R \overline{3}$ with $a=9.172$ and $c=33.51 \AA$, implying $Z=3$ and structure similar to that of shigaite. They note, however, that data for motukoreaite from different sources varies: Brindley (1979) give $a=3.062$ and $c=$ $33.51 \AA$, and report one moderately strong diffraction peak corresponding to a $\sqrt{3} \times \sqrt{3}$ superstructure; Alker et al. (1981) report $c=$ $11.216 \AA$; and Ramanaidou and Noack (1987) report $a=3.065$ and $c=33.47 \AA$. The data of $\operatorname{Rad}$ (1974) for an unnamed phase that appears to be motukoreaite are $a=3.057$ and $c=11.18 \AA$. Ramanaidou and Noack (1987) report the coexistence of motukoreaite with a related but sulfate- and carbonate-free Mg-Al hydroxide, with the unit cell $a=3.045$ and $c=22.68 \AA$ in a palagonite. It appears that a $3 \times 3$ or $\sqrt{ } 3 \times \sqrt{ } 3$ superstructure in the $x y$ plane may or may not be present, and that 1,2,3 and 4-layer polytypes may exist.

It is not apparent why motukoreaite is so much more variable in composition and structure, and so poorly crystallized in comparison to wermlandite, shigaite and nikischerite. The compositional variability of motukoreaite suggests that careful chemical characterization might lead to its division into several species on the basis of the dominance of carbonate or sulfate as the interlayer anion, and occupancy of the $\mathrm{Na}$ site (greater or less than 50\%). The type material may represent the $\left[\mathrm{Mg}_{6} \mathrm{Al}_{3}(\mathrm{OH})_{18}\right]\left[\square\left(\mathrm{H}_{2} \mathrm{O}\right)_{6}\right]$ $\left[\mathrm{HCO}_{3}\right]\left[\mathrm{SO}_{4}\right] \cdot 6 \mathrm{H}_{2} \mathrm{O}$ endmember, whereas the Humicki and Hawthorne (2003) formula is nearer to a $\left[\mathrm{Mg}_{6} \mathrm{Al}_{3}(\mathrm{OH})_{18}\right]\left[\mathrm{Na}\left(\mathrm{H}_{2} \mathrm{O}\right)_{6}\right]$ $\left[\mathrm{SO}_{4}\right]_{2} \cdot 6 \mathrm{H}_{2} \mathrm{O}$ endmember. However, the available data are not yet sufficient to reliably list the species that have been observed or to nominate type localities.

\section{Natroglaucocerinite}

Natroglaucocerinite occurs at several mines in the Lavrion District of Greece. It was approved by the IMA in 1995 (IMA1995-025), but a full description remains to be published. An abstract by Witzke et al. (1995) gives the formula,
$\left[\mathrm{Zn}_{5} \mathrm{Al}_{3}(\mathrm{OH})_{16}\right] \mathrm{Na}_{1.5}\left(\mathrm{SO}_{4}\right)_{2.25} \cdot 9 \mathrm{H}_{2} \mathrm{O}$, which is close to that of glaucocerinite, but with additional interlayer $\mathrm{Na}^{+}$and $\left[\mathrm{SO}_{4}\right]^{2-}$. Given the $\mathrm{Na}$ content, natroglaucocerinite can be considered to be member of the wermlandite group, and the formula can be recalculated on the basis of $18(\mathrm{OH})$ as $\left[\mathrm{Zn}_{5.63} \mathrm{Al}_{3.37}(\mathrm{OH})_{18}\right] \mathrm{Na}_{1.68}\left(\mathrm{SO}_{4}\right)_{2.53}$ $.9 .13 \mathrm{H}_{2} \mathrm{O}$, which is comparable to $\left[\mathrm{Zn}_{6} \mathrm{Al}_{3}(\mathrm{OH})_{18}\right]\left[\mathrm{Na}\left(\mathrm{H}_{2} \mathrm{O}\right)_{6}\right]\left[\mathrm{SO}_{4}\right]_{2} \cdot 6 \mathrm{H}_{2} \mathrm{O}$, the hypothetical $\mathrm{Zn}$ analogue of shigaite, nikischerite and motukoreaite, but with a higher interlayer $\mathrm{Na}^{+}$ and $\left[\mathrm{SO}_{4}\right]^{2-}$ content and less water than in the rest of the group. Clearly, natroglaucocerinite is not the $\mathrm{Na}$ analogue of glaucocerinite sensu stricto, as the name might be taken to imply.

\section{Karchevskyite}

Karchevskyite was described by Britvin et al. (2008) as pearly white spherulites from the Zheleznyi mine, Kovdor carbonatite massif, Kola Peninsula, Russia. The empirical formula $\left[\mathrm{Mg}_{18} \mathrm{Al}_{9}(\mathrm{OH})_{54}\right]\left(\mathrm{Sr}_{1.79} \mathrm{Mg}_{0.48} \mathrm{Ca}_{0.09}\right)_{\Sigma 2.36}$ $\left(\mathrm{CO}_{3}\right)_{8.26}\left(\mathrm{PO}_{4}\right)_{0.46}\left(\mathrm{H}_{2} \mathrm{O}\right)_{6.54}\left(\mathrm{H}_{3} \mathrm{O}\right)_{4.18}$, can be simplified to produce the endmember formula $\left[\mathrm{Mg}_{18} \mathrm{Al}_{9}(\mathrm{OH})_{54}\right] \mathrm{Sr}_{2}\left(\mathrm{CO}_{3}\right)_{9}\left(\mathrm{H}_{2} \mathrm{O}\right)_{6}\left(\mathrm{H}_{3} \mathrm{O}\right)_{5}$. The high degree of protonation of the interlayer water molecules, replacement of carbonate by phosphate, dominance of $\mathrm{Sr}^{2+}$ as the large interlayer cation (although at a very low occupancy of 2 per 27 octahedral cations) are all distinctive. The unit cell is trigonal $P$, with dimensions $a=16.0556, c=25.66 \AA$ and $Z=3$. Karchevskyite has a $2 T$ polytype, but it has an unusually large $\sqrt{ } 27 \times \sqrt{ } 27$ superstructure in the $x y$ plane, presumably due to ordering of the interlayer species.

\section{Cualstibite}

Cualstibite, ideally $\mathrm{Cu}_{2} \mathrm{Al}(\mathrm{OH})_{6}\left[\mathrm{Sb}(\mathrm{OH})_{6}\right]$, was described from the Clara mine, Oberwolfach, Germany by Walenta (1984), and is the archetype of a small group of LDH phases in which the $M^{2+}: M^{3+}$ ratio is $2: 1$ as in the quintinite group, but the intercalated anion is hexahydroxyantimonate, $\left[\mathrm{Sb}^{5+}(\mathrm{OH})_{6}\right]^{-}$, without additional water. The space group is $P \overline{3}$, and unit-cell parameters are $a=9.15$, $c=9.745 \AA$, with $Z=3$, which implies a $1 T$ polytype with a $3 \times 3$ superstructure in the $x y$ plane. Whereas the layer periodicity of hydrotalcite and quintinite group minerals is $7.5-8 \AA$, the larger octahedral anion of cualstibite increases the periodicity to $9.7 \AA$. 


\section{Cyanophyllite}

Cyanophyllite was described from the Clara mine by Walenta (1981). It has a different $\mathrm{Cu}: \mathrm{Al}: \mathrm{Sb}$ ratio to cualstibite, contains trivalent $\mathrm{Sb}$, and has a relatively low water content. A re-examination by Kolitsch and Giester (2007) and Kolitsch et al. (in press) reported the same composition as cualstibite, with a monoclinic $P 2_{1} / c$ cell with $a=$ 9.941, $b=8.899$ (which is $\sim \sqrt{ } 3 c$ ) $, c=5.498 \AA, \beta$ $=102.88^{\circ}$ and $Z=2$. The brucite-like layers are parallel to (100) (Kolitsch et al., in press). The layer spacing, $a \sin \beta$, is $9.691 \AA$, and the layer offset $-a \cos \beta$ is $2.216 \AA$ which is $0.40 c$. Cyanophyllite and cualstibite therefore are $1 M$ and $1 T$ stacking variants of the same species. Although the name cyanophyllite has historical priority over cualstibite, the poorer quality of the original data means that the name cualstibite is preferred (as discussed in the following text).

\section{Zincalstibite}

Zincalstibite, $\mathrm{Zn}_{2} \mathrm{Al}(\mathrm{OH})_{6}\left[\mathrm{Sb}(\mathrm{OH})_{6}\right]$, the $\mathrm{Zn}$ analogue of cualstibite, was described from the Fantiscritti quarry, Carrara, Tuscany, Italy by Bonaccorsi et al. (2007). The space group $P \overline{3}$, and the unit-cell parameters $a=5.327$ and $c=$ $9.792 \AA$ A, with $Z=1$, correspond to a $1 T$ polytype with $\sqrt{3} \times \sqrt{3}$ superstructure in the $x y$ plane. Recently, Mills et al. (2012a) described a 9-layer polytype, which has the longest periodicity of an LDH mineral reported to date. This $9 R$ polytype crystallizes in space group $R \overline{3}$, its unit-cell parameters are $a=5.340(2)$ and $c=88.01(2) \AA$, with $Z=9$; it has a $\sqrt{3} \times \sqrt{3}$ superstructure in the $x y$ plane.

\section{Omsite}

Omsite (IMA2012-025), ideally $(\mathrm{Ni}, \mathrm{Cu})_{2} \mathrm{Fe}(\mathrm{OH})_{6}$ $\left[\mathrm{Sb}(\mathrm{OH})_{6}\right]$, is the $\mathrm{Ni}-\mathrm{Fe}$ analogue of cualstibite and zincalstibite; the type locality is Correc d'en Llinassos, Oms, Pyrénées-Orientales département, France (Mills et al., 2012b). Omsite crystallizes in space group $P \overline{3}$, and its unit cell parameters are $a$ $=5.351$ and $c=19.5802=2 \times 9.7901 \AA$, with $Z=$ 2 , which corresponds to a $2 T$ polytype with $\sqrt{ } 3 \times \sqrt{ } 3$ superstructure in the $x y$ plane.

\section{Hydrocalumite}

Hydrocalumite provides the prototype for the calcium aluminate LDH phases. Although rare as minerals, a wide range of synthetic examples of these substances have been studied and they are important constituents of Portland cements. The divalent cation in the layers of these materials is $\mathrm{Ca}$, the trivalent cation is typically $\mathrm{Al}$ (although $\mathrm{Fe}^{3+}$ is present in some synthetic analogues). The divalent and trivalent cations are strongly ordered and the Ca:Al ratio is always $2: 1$. Due to the larger size of $\mathrm{Ca}^{2+}$ in comparison to $\mathrm{Mg}^{2+}$, the distance between atoms in the brucite-like $x y$ plane increases, and the $\mathrm{Ca}$ cation acts as a seventh ligand to one of the interlayer water molecules. Hydrocalumite was first described from the skarn at Scawt Hill, County Antrim, Northern Ireland by Tilley et al. (1934), with an approximate formula $\left[\mathrm{Ca}_{4} \mathrm{Al}_{2}(\mathrm{OH})_{12}\right](\mathrm{OH})_{1.56}$ $\left(\mathrm{CO}_{3}\right)_{0.22} \cdot 4.76 \mathrm{H}_{2} \mathrm{O}$ [the formula has been normalized to $6(\mathrm{Ca}+\mathrm{Al})$ for comparative purposes]. Passaglia and Sacerdoti (1988) reviewed published compositions of hydrocalumite from various localities and concluded that they lay in a ternary solid solution with endmember formulae $\left[\mathrm{Ca}_{4} \mathrm{Al}_{2}(\mathrm{OH})_{12}\right] \mathrm{Cl}_{2} \cdot 4 \mathrm{H}_{2} \mathrm{O}-\left[\mathrm{Ca}_{4} \mathrm{Al}_{2}(\mathrm{OH})_{12}\right](\mathrm{OH})_{2}$ $\cdot 6 \mathrm{H}_{2} \mathrm{O}-\left[\mathrm{Ca}_{4} \mathrm{Al}_{2}(\mathrm{OH})_{12}\right]\left(\mathrm{CO}_{3}\right) \cdot 6 \mathrm{H}_{2} \mathrm{O}$. The original specimens from Scawt Hill correspond to the hydroxide endmember. However, the analyses collated by Passaglia and Sacerdoti (1988) revealed a chloride-dominant endmember [e.g. at Bellerberg in Germany, where material described by Fischer et al. (1980) corresponds to $\left.\left[\mathrm{Ca}_{4} \mathrm{Al}_{2}(\mathrm{OH})_{12}\right] \mathrm{Cl}_{1.90}(\mathrm{OH})_{0.10} \cdot 4 \mathrm{H}_{2} \mathrm{O}\right]$. The carbonate endmember was not dominant in any of the collated analyses. Due to the larger size of the $\mathrm{Ca}^{2+}$ ion, the pseudohexagonal repeat $a_{\mathrm{psh}}$ in the $(\mathrm{Ca}, \mathrm{Al})(\mathrm{OH})_{2}$ sheet is $\sim 5.7 \AA$ rather than $\sim 3.1 \AA$ as in the Mg-rich phases. Cation ordering and interlayer offsets result in a monoclinic cell for most hydrocalumite-related phases, the orthogonal net of the hydroxide layer having $a$ $\sqrt{ } 3 a_{\mathrm{psh}}=9.953 \AA$ (Cl-rich, Bellerberg) or $10.047 \AA\left(\mathrm{OH}-\right.$ and $\mathrm{CO}_{3}$-rich, Montalto di Castro, Viterbo, Italy) and $b \sim 2 a_{\mathrm{psh}}=11.466 \AA$ (Bellerberg) or $11.523 \AA$ (Montalto di Castro). The $c$ repeats are 16.292 and $16.271 \AA$, respectively, with $\beta=104.46^{\circ}$ and $104.31^{\circ}$ and $Z=4$ for the formulae given above. The layer spacing is thus $1 / 2 c \sin \beta=7.89 \AA$, which is similar to those of the hydrotalcite and quintinite groups. The space group is $P 2 / c$, but there is a strong $C 2 / c$ subcell with $b_{\text {subcell }}=b_{\text {cell }} / 2$ (Sacerdoti and Passaglia, 1988). A second specimen from Bellerberg with a formula $\left[\mathrm{Ca}_{4} \mathrm{Al}_{2}(\mathrm{OH})_{12}\right] \mathrm{Cl}_{1.60}$ $(\mathrm{OH})_{0.40} \sim 4 \mathrm{H}_{2} \mathrm{O}$ has been reported as rhombohedral, with space group $R \overline{3} c$, and unit-cell 
dimensions of $a=5.765$ and $c=6 \times 7.630=$ $46.978 \AA$ (Fischer et al., 1980). Thus, both $2 M$ and $6 T$ polytypes, with similar compositions, coexist at Bellerberg. Sacerdoti and Passaglia (1988) refined the structure of hydrocalumite from Montalto di Castro and found that the $\mathrm{CO}_{3}$ has long-range ordering; they reported the structural formula $\left[\mathrm{Ca}_{8} \mathrm{Al}_{4}(\mathrm{OH})_{24}\right]\left(\mathrm{CO}_{3}\right)$ $\mathrm{Cl}_{2}\left(\mathrm{H}_{2} \mathrm{O}\right)_{1.6} \cdot 8 \mathrm{H}_{2} \mathrm{O}$. They found that the doubling of $b$ is due to ordering of the interlayer anions and does not occur for the $C 2 / c$ synthetic $\mathrm{Cl}$ endmember. Sacerdoti and Passaglia (1988) noted that various ordering schemes which maintain a continuous hydrogen-bonding network are possible, and also discussed the polytypic behaviour of various hydrocalumite analogues. A case can be made for the division of the $\mathrm{OH}$ - and $\mathrm{Cl}$-dominant hydrocalumites into separate species. Species divisions on the basis of subsidiary quantities of carbonate can also be justified if long-range order is present.

\section{Kuzelite}

Kuzelite, $\left[\mathrm{Ca}_{4} \mathrm{Al}_{2}(\mathrm{OH})_{12}\right]\left[\left(\mathrm{SO}_{4}\right) \cdot 6 \mathrm{H}_{2} \mathrm{O}\right.$, was described from carbonaceous xenoliths found at Zeilberg quarry, Bavaria, Germany by Pollmann et al. (1997). It forms colourless to white platy microcrystals which crystallize in space group $R \overline{3}$, and has a unit cell with $a=5.76, c=6 \times 8.943=$ $53.66 \AA$ and $Z=3$. Kuzelite is the sulfate analogue of hydrocalumite. Spectroscopic data indicate that carbonate is absent from the structure. The increase in layer spacing from 7.6 to $8.9 \AA$, due to substitution of sulfate for carbonate, is very similar to that between the hydrotalcite and woodwardite groups. However, due the small number of Ca-rich hydrotalcitesupergroup species, the increase in layer spacing has not been proposed as a criterion for group separation.

\section{Coalingite}

Coalingite, $\mathrm{Mg}_{10} \mathrm{Fe}_{2}^{3+}(\mathrm{OH})_{24}\left[\mathrm{CO}_{3}\right] \cdot 2 \mathrm{H}_{2} \mathrm{O}$, forms red-brown to golden-brown crusts of microscopic platelets, and was originally reported from the New Idria Serpentinite, San Benito and Fresno Counties, California, USA by Mumpton et al. (1965). The material had previously been described as 'ferrobrucite'. Coalingite is almost always of endmember composition, and has $1 / 6$ of the cations trivalent rather than $1 / 4$ as in pyroaurite. It is thus very close in composition to brugnatellite, but with a much lower water content. The structure reported by PastorRodriguez and Taylor (1971) has a unit cell with $a=3.12, c=3 \times 12.47=37.4 \AA$ and $Z=1 / 2$, in space group $R \overline{3} 2 \mathrm{~m}$, which indicates that there is no long-range $\mathrm{Mg}-\mathrm{Fe}$ order within sheets or $\mathrm{CO}_{3}-\mathrm{H}_{2} \mathrm{O}$ order in the interlayer. Broadened reflections and streaking parallel to $\mathbf{c}^{*}$ indicate stacking disorder. In particular, the (0003) reflection was reported to lie on a streak extending from about 0.04 to $0.14 \AA^{-1}$, with a diffuse maximum corresponding to $13.5 \AA$ rather than the expected $12.5 \mathrm{~A}$. A distinctive feature of the structure is that only every second interlayer is occupied, giving alternating spacings between $(\mathrm{Mg} / \mathrm{Fe})$ planes along $c$ of about $7.8 \AA$ and $4.7 \AA$, which are similar to those of pyroaurite and brucite, respectively. In effect, coalingite is a 1:1 interstratification of these minerals.

\section{Brugnatellite}

Brugnatellite was described from Val Malenco, Sondrio, Lombardy, Italy, by Artini (1909). His calculated formula, $\mathrm{Mg}_{6} \mathrm{Fe}^{3+}(\mathrm{OH})_{13}\left[\mathrm{CO}_{3}\right] \cdot 4 \mathrm{H}_{2} \mathrm{O}$, includes carbonate, and is still quoted today. The X-ray study of Fenoglio (1938) reported a primitive trigonal symmetry with $a=5.47 \AA$ and $c=15.97 \AA$. If these observations are valid, the mineral can be distinguished from pyroaurite/ sjögrenite by having only $1 / 7$ of the octahedral cations trivalent, rather than $1 / 3$, having a $\sqrt{3} \times \sqrt{ } 3$ superstructure in the $x y$ plane, and a distinctive space group symmetry. The $c$ repeat indicates that the low $M^{3+}$ content cannot be due to alternation of pyroaurite- and brucite-like stacking as in coalingite. Frondel (1941) noted that the same composition was reported for brugnatellite from four different Italian localities, but that his own examination of material from Val Malenco and Val Ramazzo showed samples labelled "brugnatellite" to consist largely of mixtures pyroaurite and brucite with additional minor phases. Nevertheless, Frondel (1941) concluded that brugnatellite was probably a distinct phase that coexisted with pyroaurite at these localities.

In common with carrboydite and mountkeithite, brugnatellite has $\left(M^{2+}+M^{3+}\right):(\mathrm{OH})^{-}>1: 2$. However, the $c$ spacing is similar to that of a 2-layer member of the hydrotalcite or quintinite groups, so interlayer octahedral cations are unlikely to be present. Rewriting the formula as $\mathrm{Mg}_{6} \mathrm{Fe}^{3+}(\mathrm{OH})_{14}\left[\mathrm{HCO}_{3}\right] \cdot 3 \mathrm{H}_{2} \mathrm{O}$ would eliminate this anomaly. Note also that the formula with 7 
octahedral cations is not compatible with the 3 -fold superstructure in the $x y$ plane, and a reformulation as $\mathrm{Mg}_{5.14} \mathrm{Fe}_{0.86}^{3+}(\mathrm{OH})_{12}\left[\mathrm{HCO}_{3}\right]_{0.86}$ $\cdot 2.57 \mathrm{H}_{2} \mathrm{O}$ may be even more appropriate. Brugnatellite requires re-examination to determine its true stoichiometry and interlayer speciation.

\section{Muskoxite}

Muskoxite was described as red-brown finegrained crystals in a drill core from the Muskox intrusion, Kitikmeot Region, Nunavut, Canada by Jambor (1969b). Precession X-ray photographs revealed $P \overline{3} \mathrm{~m} 1$ symmetry with a strong $a=3.07$ and $c=4.6 \AA$ subcell. However, numerous closely spaced reflections along $\mathrm{c}^{*}$ indicated that the true periodicity or periodicities were much longer. Chemical analysis of $200 \mathrm{mg}$ of hand-picked material gave the overall formula (based on 8 cations) $\mathrm{Mg}_{5.04} \mathrm{Fe}_{2.96}^{3+} \mathrm{O}_{9.48} \cdot 7.54 \mathrm{H}_{2} \mathrm{O}$, with $<1 \% \mathrm{CO}_{2}$ and all $\mathrm{Fe}$ assumed to be trivalent. This analysis has insufficient water to fit into a hydrotalcite-group template, as $M:[\mathrm{O}+\mathrm{OH}+$ $\left.\mathrm{H}_{2} \mathrm{O}\right]=1: 2.13$ rather than $1: 2.75(8: 22)$ as would be expected for a hydroxide member of the hydrotalcite group or $1: 2.83$ (6:17) for a quintinite-like phase. The $4.6 \AA$ subperiodicity along $c$, which is close to the layer spacing of brucite, and the low water content, suggest that muskoxite may not be the hydroxide analogue of sjögrenite. Microprobe analyses of veinlet material gave $\mathrm{Mg}: \mathrm{Fe}: \mathrm{Mn}$ atomic ratios of 38.2:57.5:4.3 and 22.6:71.8:5.6, implying a wide range of $\mathrm{Mg}: \mathrm{Fe}: \mathrm{Mn}$ compositions and probably a range of $\mathrm{Fe}$ oxidation states. In the absence of constraints on the latter, it is not possible to determine whether the solid solution spans Mgdominant and $\mathrm{Fe}^{2+}$-dominant species. Further investigation is required.

\section{Status of the minerals in the hydrotalcite supergroup}

\section{Discreditations and questionable species}

According to Nickel and Grice (1998): "Polytypes and polytypoids are not regarded as separate species and, like topologically similar polymorphs, they can be distinguished by the addition of a crystallographic suffix to the mineral name, as indicated in a later section." As such, the well established polytypes of the hydrotalcite supergroup can no longer be considered to be separate species. Considering only the stacking of layers (and neglecting any differences in the layer superstructures), the following mineral names are invalid (see also Table 2): manasseite (= hydrotalcite- $2 H$ ), sjögrenite (= pyroaurite- $2 H$ ), barbertonite (= stichtite- $2 H)$ and cyanophyllite (= cualstibite- $1 M)$. Hydrotalcite, pyroaurite and stichtite are preferred on the basis of historical precedence. In the case of cyanophyllite and cualstibite, cualstibite is preferred, despite being described later (1984 vs. 1981), because the chemistry, valence states and crystallography were initially described incorrectly for cyanophyllite. A complete description of the cyanophyllite structure is provided by Kolitsch et al. (in press).

Jamborite, carrboydite, zincaluminite, motukoreaite, natroglaucocerinite, muskoxite and brugnatellite are all considered to be questionable species on the basis of their poorly defined chemical compositions. In each case, the chemistry is not sufficiently well defined to associate the name with a unique formula which is distinct from all others; however, each of the species is probably valid and a member of the hydrotalcite supergroup. Fougèrite is redefined as two distinct species, fougèrite and trébeurdenite (see below). The current status of all of the members of the hydrotalcite supergroup is summarized in Table 2. We emphasize that the status is that of a name, not of a composition range. There has been ambiguity and inconsistency in the usage and interpretation of status categories in the past; in order to avoid this with the hydrotalcite group, they are defined here as follows:

'A' (approved): the name has been approved by the CNMNC or its predecessor Commission as a valid name for the mineral species.

' $\mathrm{D}$ ' (discredited): the name is no longer the official name for a mineral species, as it is now regarded as a synonym, a varietal name, or was so poorly defined in the first place that it cannot be applied in a reproducible fashion.

' $G$ ' (grandfathered): the name is an old one that pre-dates the Commissions, but is generally accepted as valid.

'Group': the name now refers to a group within the supergroup. Names of groups may coincide with names of valid species, giving the status 'A + Group'. The groups are discussed in detail in the following text.

'Q' (questionable): the name refers to one or more mineral species, which are probably valid, but type material was not well enough characterized for species to be unambiguously identified by current criteria. Further study will allow reclassification of the name as 'A' or 'D'. 
TABLE 2. The minerals of the hydrotalcite supergroup as at March 2009, the current status of the names (this report), and their new status as approved by the CNMNC in 2012.

\begin{tabular}{|c|c|c|c|}
\hline Mineral name & $\begin{array}{l}\text { IMA status } \\
(2009)\end{array}$ & $\begin{array}{l}\text { IMA status } \\
\quad(2012)\end{array}$ & Comment \\
\hline Hydrotalcite & $\mathrm{G}$ & $\begin{array}{l}\text { G/Rd + Group }+ \\
\quad \text { Supergroup }\end{array}$ & incorporates former manasseite \\
\hline Manasseite & G & $\mathrm{D}$ & $=$ hydrotalcite \\
\hline Pyroaurite & G & $\mathrm{G} / \mathrm{Rd}$ & incorporates former sjögrenite \\
\hline Sjögrenite & G & $\mathrm{D}$ & $=$ pyroaurite \\
\hline Stichtite & $\mathrm{G}$ & $\mathrm{G} / \mathrm{Rd}$ & incorporates former barbertonite \\
\hline Barbertonite & $\mathrm{Q}$ & $\mathrm{D}$ & $=$ stichtite \\
\hline Meixnerite & A & A & \\
\hline Iowaite & A & A & \\
\hline Droninoite & A & A & \\
\hline Woodallite & A & A & \\
\hline Desautelsite & A & A & \\
\hline Takovite & A & A & \\
\hline Reevesite & A & A & \\
\hline Jamborite & A & Q & \\
\hline Quintinite & A & $\mathrm{A}+$ Group & \\
\hline Charmarite & A & A & \\
\hline Caresite & A & A & \\
\hline Zaccagnaite & A & A & \\
\hline Chlormagaluminite & A & A & \\
\hline Comblainite & A & A & \\
\hline Fougèrite & A & $\mathrm{A} / \mathrm{Rd}+$ Group & $=$ fougèrite + trébeurdenite \\
\hline Woodwardite & $\mathrm{G}$ & A + Group & \\
\hline Zincowoodwardite & A & A & \\
\hline Honessite & A & A & \\
\hline Glaucocerinite & G & $\mathrm{A}+$ Group & \\
\hline Hydrowoodwardite & A & A & $\begin{array}{l}\text { some may be new species with } \mathrm{Al} \\
\qquad>\mathrm{Cu}\end{array}$ \\
\hline Carrboydite & A & Q & \\
\hline Hydrohonessite & A & A & \\
\hline Mountkeithite & A & A & \\
\hline Zincaluminite & $\mathrm{Q}$ & $\mathrm{Q}$ & = glaucocerinite? \\
\hline Wermlandite & A & $A+$ Group & \\
\hline Shigaite & A & A & \\
\hline Nikischerite & A & A & \\
\hline Motukoreaite & A & Q & may correspond to $>1$ species \\
\hline Natroglaucocerinite & A & Q & \\
\hline Karchevskyite & A & A & \\
\hline Cualstibite & A & $\mathrm{A} / \mathrm{Rd}+$ Group & incorporates former cyanophyllite \\
\hline Cyanophyllite & A & $\mathrm{D}$ & $=$ cualstibite \\
\hline Zincalstibite & A & A & \\
\hline Hydrocalumite & G & $\mathrm{G}+$ Group & may correspond to $>1$ species \\
\hline Kuzelite & A & A & \\
\hline Coalingite & A & A & \\
\hline Brugnatellite & G & Q & \\
\hline Muskoxite & A & Q & may correspond to $>1$ species \\
\hline
\end{tabular}

'Rd' (redefined): the currently valid name now refers to a range of chemical or structural variation for the species that is narrower, broader or otherwise different from that before the redefinition. This is a temporary category highlighting that there is a discredited older name 
referring to the same mineral as a result of recent changes; ' $\mathrm{Rd}$ ' status is thus additional to ' $\mathrm{A} / \mathrm{G}$ ' status.

'Rn' (renamed): the currently valid name replaced an earlier name without any change in the scope. This is also a temporary category that is supplemental to ' $\mathrm{A} / \mathrm{G}$ ' status and flags a recent change. 'Rn' emphasizes that some specimens that used to carry the current name may no longer do so, whereas other specimens that used to be named differently may now carry the current name.

'Supergroup': the name now refers to the supergroup.

\section{Redefinition of fougèrite}

Mössbauer spectroscopy is the most reliable technique for quantitatively determining the proportions of $\mathrm{Fe}^{2+}$ and $\mathrm{Fe}^{3+}$ in green rust. As the Mössbauer spectra of the natural samples must be compared to those of the corresponding synthetic compounds measured at $78 \mathrm{~K}$, we review the procedure for preparing the synthetic reference samples (cf. Génin et al., 2005; Aïssa et al., 2006), which is as follows: (1) $\mathrm{Fe}_{4}^{2+} \mathrm{Fe}_{2}^{3+}(\mathrm{OH})_{12} \mathrm{CO}_{3} \cdot 3 \mathrm{H}_{2} \mathrm{O}(x=1 / 2)$ is coprecipitated by mixing ferrous and ferric sulfates in a $2: 1\left[\mathrm{Fe}^{2+}\right] /\left[\mathrm{Fe}^{3+}\right]$ ratio in the presence of $\mathrm{NaHCO}_{3}$; (2) Hydrogen peroxide is introduced using a peristaltic pump into the $\mathrm{Fe}_{4}^{2+} \mathrm{Fe}_{2}^{3+}(\mathrm{OH})_{12} \mathrm{CO}_{3} \cdot 3 \mathrm{H}_{2} \mathrm{O}$ solution, and the electrode potential $E_{\mathrm{h}}$ is recorded as the $\mathrm{H}_{2} \mathrm{O}_{2}$ is added. In addition to the initial $\mathrm{Fe}_{4}^{2+} \mathrm{Fe}_{2}^{3+}(\mathrm{OH})_{12} \mathrm{CO}_{3} \cdot 3 \mathrm{H}_{2} \mathrm{O}$, four oxidation products have been characterized by transmission Mössbauer spectroscopy at $78 \mathrm{~K}$, at compositions $x=1 / 2,0.63,0.78$ and 1 .

Mössbauer spectra can be fitted in two ways: by directly superimposing Lorentzian-shaped lines, or by deconvoluting Lorentzian-shaped lines with Gaussian distributions. The first method is usually adequate, but there are cases where the second method is more appropriate. The in situ deprotonation of the $\mathrm{Fe}^{2+}-\mathrm{Fe}^{3+}$ oxyhydroxycarbonate by $\mathrm{H}_{2} \mathrm{O}_{2}$ is one of these, and this procedure was used initially. The fitted parameters are listed in Table 3, and spectra with fits are shown in Fig. 7. The intensity variation of the doublet intensities $\left(D_{1}+D_{2}\right), D_{3}$ and $D_{4}$ as a function of composition are summarized in Fig. 8.

The spectrum of the initial precipitate with $x=$ $1 / 3$ (i.e. $\mathrm{Fe}_{4}^{2+} \mathrm{Fe}_{2}^{3+}(\mathrm{OH})_{12} \mathrm{CO}_{3} \cdot 3 \mathrm{H}_{2} \mathrm{O}$ ) contains three quadrupole doublets (Fig. 7a,b); two of them, $D_{1 \mathrm{f}}$ and $D_{2 \mathrm{f}}$, have a large quadrupolar splitting of about 2.9 and $2.6 \mathrm{~mm} \mathrm{~s}^{-1}$ and a $3: 1$ intensity ratio; these are attributed to $\mathrm{Fe}^{2+}$ and constitute 50 and $16.7 \%$ of the total octahedral cations, respectively. The $D_{1 \mathrm{f}}$ profile is interpreted to correspond to $\mathrm{Fe}^{2+}$ in vertical registry with interlayer $\mathrm{H}_{2} \mathrm{O}$ molecules, whereas $D_{2 \mathrm{f}}$ is interpreted to correspond to $\mathrm{Fe}^{2+}$ in registry with the centre of a $\mathrm{CO}_{3}^{2-}$ anion. The third doublet, $D_{3}$, with a small splitting of about $0.5 \mathrm{~mm} \mathrm{~s}^{-1}$, corresponds to a unique $\mathrm{Fe}^{3+}$ site in registry with a $\mathrm{CO}_{3}^{2-}$ anion. The cations are ordered within each layer so that each $\mathrm{Fe}^{3+}$ cation is surrounded by six $\mathrm{Fe}^{2+}$ cations; this cation ordering induces interlayer anion ordering to minimize local charge imbalance. This composition corresponds to the mineral fougèrite as redefined herein, so these doublets are labelled with an ' $\mathrm{f}$ ' subscript.

The spectra evolve progressively as $\mathrm{H}_{2} \mathrm{O}_{2}$ is added to the initial precipitate. As in situ oxidation proceeds, the two quadrupole doublets with large splitting $\left(D_{1}\right.$ and $\left.D_{2}\right)$ decrease in intensity, and a second quadrupole doublet with smaller splitting appears. This shows that $\mathrm{Fe}^{2+}$ cations are oxidizing to $\mathrm{Fe}^{3+}$. At $x \sim 2 / 3$, which corresponds to the mineral trébeurdenite $\left[\mathrm{Fe}_{2}^{2+} \mathrm{Fe}_{4}^{3+} \mathrm{O}_{2}(\mathrm{OH})_{10} \mathrm{CO}_{3} \cdot 3 \mathrm{H}_{2} \mathrm{O}\right]$ two quadrupole doublets with large splitting in a $3: 1$ intensity ratio are present (these are labelled $D_{1 \mathrm{t}}$ and $D_{2 \mathrm{t}}$, where ' $t$ ' stands for 'trébeurdenite') at abundances of 25 and $8.3 \%$, respectively. There are also two distinct $\mathrm{Fe}^{3+}$ doublets, $D_{3 \mathrm{t}}$ and $D_{4 \mathrm{t}}$, of equal intensity (i.e. 33.3 and $33.3 \%$ ) (Fig. $7 e_{2}$ ). The Mössbauer parameters of the $D_{3 \mathrm{t}}$ doublet are quite similar to those of the homologous $D_{3 \mathrm{f}}$ doublet in fougèrite, but whereas the $\mathrm{Fe}^{3+}$ giving rise to $D_{3 \mathrm{f}}$ is necessarily coordinated to $6\left[\mathrm{OH}^{-}\right]$in the octahedral layer, the new $\mathrm{Fe}^{3+}$ environment associated with $D_{4 \mathrm{t}}$ contains $\mathrm{O}^{2-}$ ligands that replace $\mathrm{OH}^{-}$due to deprotonation. The Gaussian distribution of quadrupole splitting parameters most probably results from the local distortions of the octahedra surrounding $\mathrm{Fe}$ cations when $\mathrm{OH}^{-}$ ions are partially replaced by $\mathrm{O}^{2-}$ anions. For an average value of $x$ in the range $1 / 3-2 / 3$, the mechanical mixture of fougérite and trébeurdenite gives rise to four doublets $D_{1}, D_{2}, D_{3}$ and $D_{4}$ with broadened Gaussian distributions, which are not further resolved (Fig. 7c,d).

The ferric green rust mössbauerite (which is actually orange in colour) contains no $\mathrm{Fe}^{2+}$ and has an ideal formula $\mathrm{Fe}_{6}^{3+} \mathrm{O}_{4}(\mathrm{OH})_{8} \mathrm{CO}_{3} \cdot 3 \mathrm{H}_{2} \mathrm{O}$. It produces a spectrum with two $\mathrm{Fe}^{3+}$ doublets of small quadrupolar splitting, $D_{3 \mathrm{~m}}$ and $D_{4 \mathrm{~m}}$ ('m' for 
TABLE 3. Mössbauer parameters for 'green rusts' with $x=\left[\mathrm{Fe}^{3+}\right] /\left[\mathrm{Fe}_{\text {tot }}\right]$ in the range $1 / 3-1$.

\begin{tabular}{|c|c|c|c|c|c|c|c|c|}
\hline & $\begin{array}{l}\text { Quadrupole } \\
\text { doublets }\end{array}$ & $\begin{array}{c}\Delta \\
\left(\mathrm{mm} \mathrm{s}^{-1}\right)\end{array}$ & $\begin{array}{c}<\Delta> \\
\left(\mathrm{mm} \mathrm{s}^{-1}\right)\end{array}$ & $\begin{array}{c}<\rho \Delta> \\
\left(\mathrm{mm} \mathrm{s}^{-1}\right)\end{array}$ & $\begin{array}{l}R A \\
(\%)\end{array}$ & $\begin{array}{c}F \\
(\%)\end{array}$ & $\begin{array}{c}\mathrm{T} \\
(\%)\end{array}$ & $\begin{array}{c}M \\
(\%)\end{array}$ \\
\hline \multirow{3}{*}{$\begin{array}{l}x=0.33 \\
\mathrm{Fe}^{2+}\end{array}$} & & & & & & \multirow[t]{4}{*}{100} & & \\
\hline & $D_{1 \mathrm{f}}$ & 1.25 & 2.92 & 0 & 50 & & & \\
\hline & $D_{2 f}$ & 1.25 & 2.63 & 0 & 17 & & & \\
\hline $\mathrm{Fe}^{3+}$ & $D_{3 \mathrm{f}}$ & 0.48 & 0.47 & 0 & 33 & & & \\
\hline \multirow{2}{*}{$\begin{array}{l}x \sim^{1 / 2} \\
\mathrm{Fe}^{2+}\end{array}$} & & & & & & \multirow[t]{4}{*}{50} & \multirow[t]{4}{*}{50} & \\
\hline & $\begin{array}{l}D_{1 \mathrm{f}}+D_{1 \mathrm{t}} \\
D_{2 \mathrm{f}}+D_{2 \mathrm{t}}\end{array}$ & $\begin{array}{l}1.21 \\
1.21\end{array}$ & $\begin{array}{l}2.98 \\
2.72\end{array}$ & $\begin{array}{l}0.14 \\
0.16\end{array}$ & $\begin{array}{c}38 \\
12.5\end{array}$ & & & \\
\hline \multirow[t]{2}{*}{$\mathrm{Fe}^{3+}$} & $D_{3 \mathrm{f}}+D_{3 \mathrm{t}}$ & 0.49 & 0.40 & 0.15 & 33 & & & \\
\hline & $D_{4 \mathrm{t}}$ & 0.49 & 0.70 & 0.28 & 16.5 & & & \\
\hline $\begin{array}{l}x \sim 0.63 \\
\mathrm{Fe}^{2+}\end{array}$ & & & & & & \multirow[t]{5}{*}{9} & \multirow[t]{5}{*}{91} & \\
\hline $\mathrm{Fe}^{2+}$ & $D_{1 \mathrm{t}}$ & 1.24 & 2.80 & 0.15 & 28 & & & \\
\hline & $D_{2 \mathrm{t}}$ & 1.24 & 3.05 & 0.05 & 9 & & & \\
\hline \multirow[t]{2}{*}{$\mathrm{Fe}^{3+}$} & $D_{3 \mathrm{t}}$ & 0.48 & 0.49 & 0.20 & 32 & & & \\
\hline & $D_{4 \mathrm{t}}$ & 0.48 & 0.90 & 0.21 & 31 & & & \\
\hline$x \sim 0.78$ & & & & & & & \multirow[t]{4}{*}{66} & \multirow[t]{4}{*}{34} \\
\hline $\mathrm{Fe}^{2+}$ & $D_{1 \mathrm{t}}+D_{2 \mathrm{t}}$ & 1.21 & 2.89 & 0.31 & 22 & & & \\
\hline \multirow{2}{*}{$\mathrm{Fe}^{3+}$} & $D_{3 \mathrm{t}}+D_{3 \mathrm{~m}}$ & 0.47 & 0.45 & 0.32 & 35 & & & \\
\hline & $D_{4 \mathrm{t}}+D_{4 \mathrm{~m}}$ & 0.47 & 0.95 & 0.34 & 43 & & & \\
\hline$x=1$ & & & & & & & & \multirow[t]{3}{*}{100} \\
\hline \multirow[t]{2}{*}{$\mathrm{Fe}^{3+}$} & $D_{3 \mathrm{~m}}$ & 0.47 & 0.60 & 0.30 & 33 & & & \\
\hline & $D_{4 \mathrm{~m}}$ & 0.47 & 0.88 & 0.41 & 67 & & & \\
\hline
\end{tabular}

Values of $x$ experimentally obtained are approximately $1 / 2,0.63$ and 0.78 and precisely 0.33 and 1 . Spectra are measured at $78 \mathrm{~K}$ (Fig. 7) and fitted using a Voigt profile; columns are $\delta$ : isomer shift in $\mathrm{mm} \mathrm{s}^{-1}$ (reference is $\alpha$-iron at ambient temperature), $\langle\Delta\rangle$ : mean value of quadrupole splitting in $\mathrm{mm} \mathrm{s}^{-1}$ and $\langle\rho \Delta\rangle$ : its standard deviation; $R A$ (\%): relative area of peak doublets as a percentage of total intensity. The variables $F, T$ and $M$ indicate the molar percentages of fougèrite, trébeurdenite and mössbauerite, respectively, in the mixture, deduced from bulk composition according to the lever rule.

'mössbauerite'), in a 1:2 intensity ratio, which therefore account for $33.3 \%$ and $66.7 \%$ of the total intensity, respectively (Fig. $7 i, j$ ). These two doublets are produced by $\mathrm{Fe}^{3+}$ cations that are surrounded by six $\mathrm{Fe}^{3+}$ ions. The $D_{3 \mathrm{~m}}$ doublet is produced by those $\mathrm{Fe}^{3+}$ cations that initially balanced the charge on the $\mathrm{CO}_{3}^{2-}$ anions, $D_{4 \mathrm{~m}}$ is produced by $\mathrm{Fe}^{3+}$ ions associated with deprotonation. The widths of the Gaussian distributions for quadrupole splitting are much increased, particularly for $D_{4 \mathrm{~m}}\left(0.41 \mathrm{~mm} \mathrm{~s}^{-1}\right)$, as local lattice distortions are now due to $2\left[\mathrm{O}^{2-}\right]$ and $4\left[\mathrm{OH}^{-}\right]$ anions at the apices of the octahedrons surrounding $\mathrm{Fe}^{3+}$ ions. For an average $x$ value in the range $2 / 3-1$, the mechanical mixture of trébeurdenite and mössbauerite gives rise to only three Gaussian distributions of quadrupole doub- lets $\left(D_{1}+D_{2}\right), D_{3}$ and $D_{4}$ (Fig. $\left.7 g, h\right)$. The two ferrous contributions can no longer be resolved, and merge into a single broader distribution.

Despite the change in $x$, the structure of the green rusts remains constant, in space group $R \overline{3} \mathrm{~m}$ (Fig. 9), as shown by their X-ray diffraction patterns (Fig. 10). The measured unit-cell parameters are $a=3.182 \AA$ and $c=22.896=$ $3 \times 7.632 \AA$ at $x=1 / 3$; and $a=3.173 \AA$ and $c=$ $22.695=3 \times 7.565 \AA$ at $x=2 / 3$. At $x=1$, the unitcell parameters are $a=3.079 \AA$ and $c=22.253=$ $3 \times 7.418 \AA$. The absence of a supercell in the $x y$ plane $(a \sim 3 \AA)$ shows that the 3-layer repeat arises from offsets of octahedral layers across the interlayers rather than from long-range order of $\mathrm{Fe}^{2+}$ and $\mathrm{Fe}^{3+}$ or of the interlayer contents. Although low-temperature Mössbauer and 

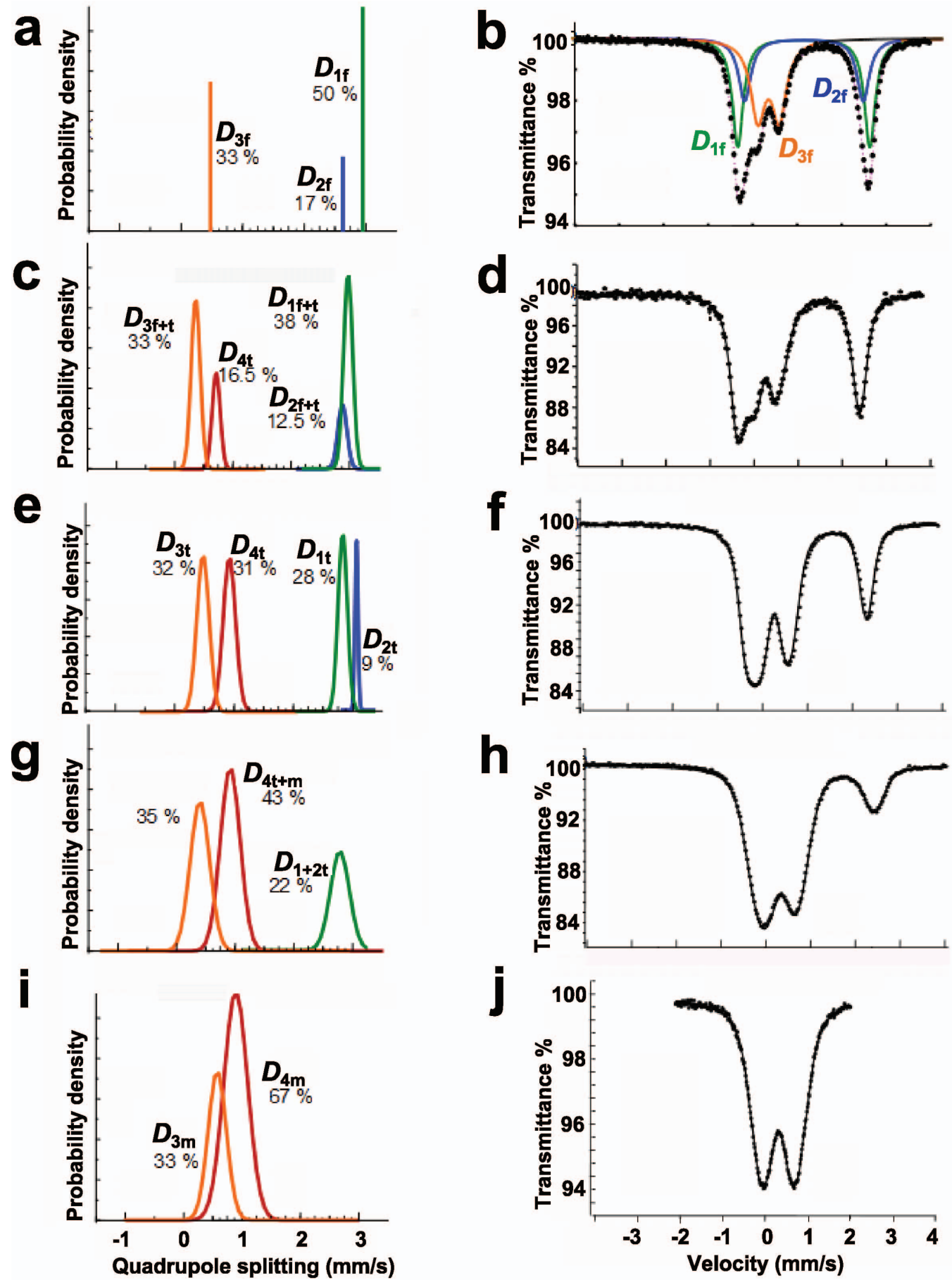

FIG. 7. Mössbauer spectra measured at $78 \mathrm{~K}$ of synthetic green rust samples for values of $x=\left[\mathrm{Fe}^{3+}\right] /\left[\mathrm{Fe}_{\text {tot }}\right]$ in the range $1 / 3-1$. (a) Probability density for Gaussian distributions of quadrupole splittings fitted using Voigt-function profiles, and $(b)$ total spectrum showing fitted doublets for $x=1 / 3 ;(c)$ and $(d)$ are corresponding data for $x=1 / 2$; $(e)$ and $(f)$ for $x=0.63 ;(g)$ and $(h)$ for $x=0.78 ;(i)$ and $(j)$ for $x=1$. 


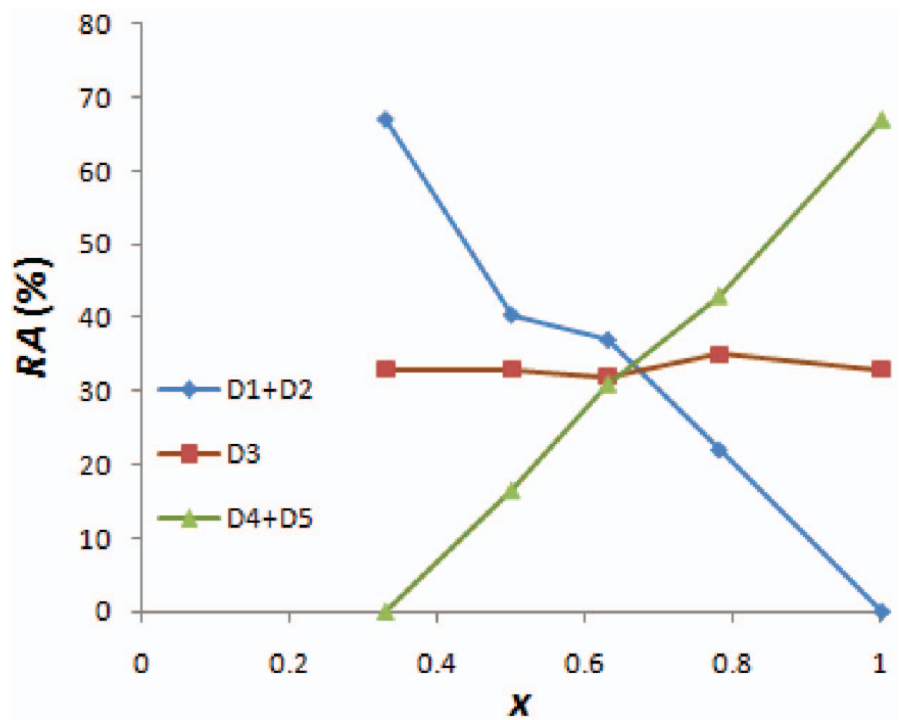

FIG. 8. Relative areas of the Mössbauer doublets $D_{1 \mathrm{f}+\mathrm{t}}+D_{2 \mathrm{f}+\mathrm{t}}, D_{3 \mathrm{f}+\mathrm{t}+\mathrm{m}}$ and $D_{4 \mathrm{t}+\mathrm{m}}$ from Table 3 as a function of composition $x$.

magnetic susceptibility data show strong cation order within layers, there is clearly no strong coupling between layers.

As $x$ increases, $\mathrm{OH}^{-}$ions surrounding the octahedral cations are deprotonated. The consequent shortening of bond distances causes a lattice contraction which shifts the diffraction lines towards higher angles, and also results in distortion of the octahedra (Génin et al., 2006c). These changes are well illustrated by the behaviour of the main $d_{003}$ diffraction peak as $x$ increases, although this peak is very hard to distinguish in mössbauerite $(x=1)$, due to broadening and decrease in intensity caused by local strain (Fig. 10). In synthetic samples with $x=1$, the $d_{101}$ reflection becomes dominant, however $d_{003}$ remains the diagnostic reflection (Génin et al., 2012b). In contrast, there is no change with oxidation in the external morphology of the hexagonal crystals as observed by transmission electron microscopy (Fig. 11), although the $x=1$ sample of Fig. $11 \mathrm{c}$ has rings rather than spots in its electron diffraction pattern, produced by severe rotational disorder (Génin et al., 2006c). The occurrence of a carbonated green
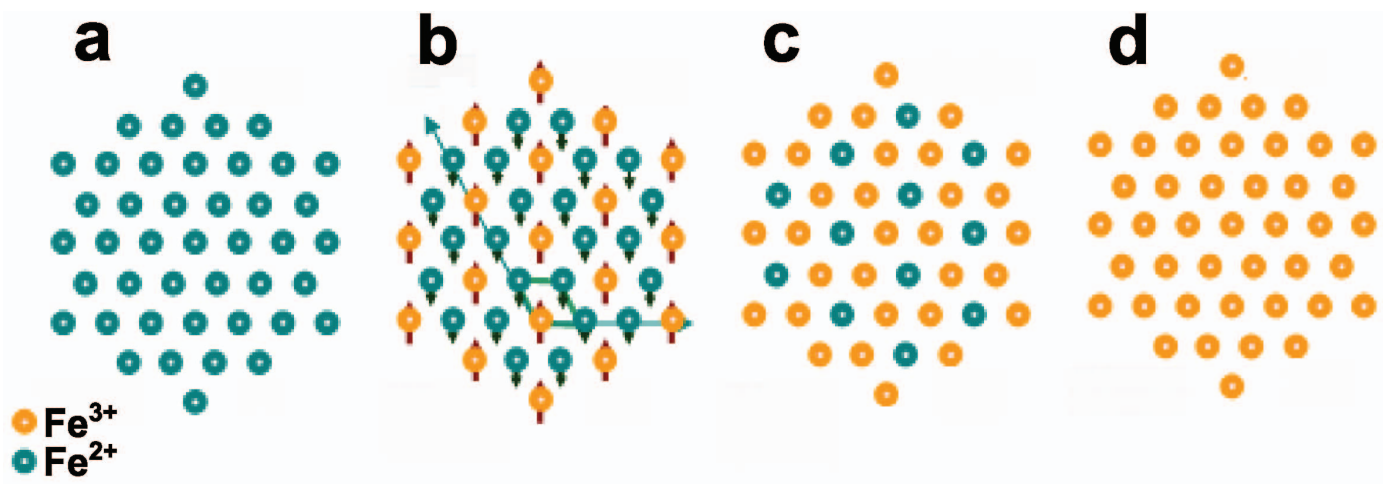

FIG. 9. Ordering of $\mathrm{Fe}^{2+}$ and $\mathrm{Fe}^{3+}$ cations within the octahedral layer, which leads to various magnetic properties: (a) $\mathrm{Fe}_{6}^{2+}(\mathrm{OH})_{10}\left(\mathrm{H}_{2} \mathrm{O}\right)_{2} \mathrm{CO}_{3} \cdot 3 \mathrm{H}_{2} \mathrm{O} ;($ b $) \mathrm{Fe}_{4}^{2+} \mathrm{Fe}_{2}^{3+}(\mathrm{OH})_{12} \mathrm{CO}_{3} \cdot 3 \mathrm{H}_{2} \mathrm{O}$, showing antiferromagnetic coupling of spins of $\mathrm{Fe}^{2+}$ and $\mathrm{Fe}^{3+}$ cations; (c) $\mathrm{Fe}_{2}^{2+} \mathrm{Fe}_{4}^{3+} \mathrm{O}_{2}(\mathrm{OH})_{10} \mathrm{CO}_{3} \cdot 3 \mathrm{H}_{2} \mathrm{O}$; (d) $\mathrm{Fe}_{6}^{3+} \mathrm{O}_{4}(\mathrm{OH})_{8} \mathrm{CO}_{3} \cdot 3 \mathrm{H}_{2} \mathrm{O}$. Modified after Genin $e t$ al. 

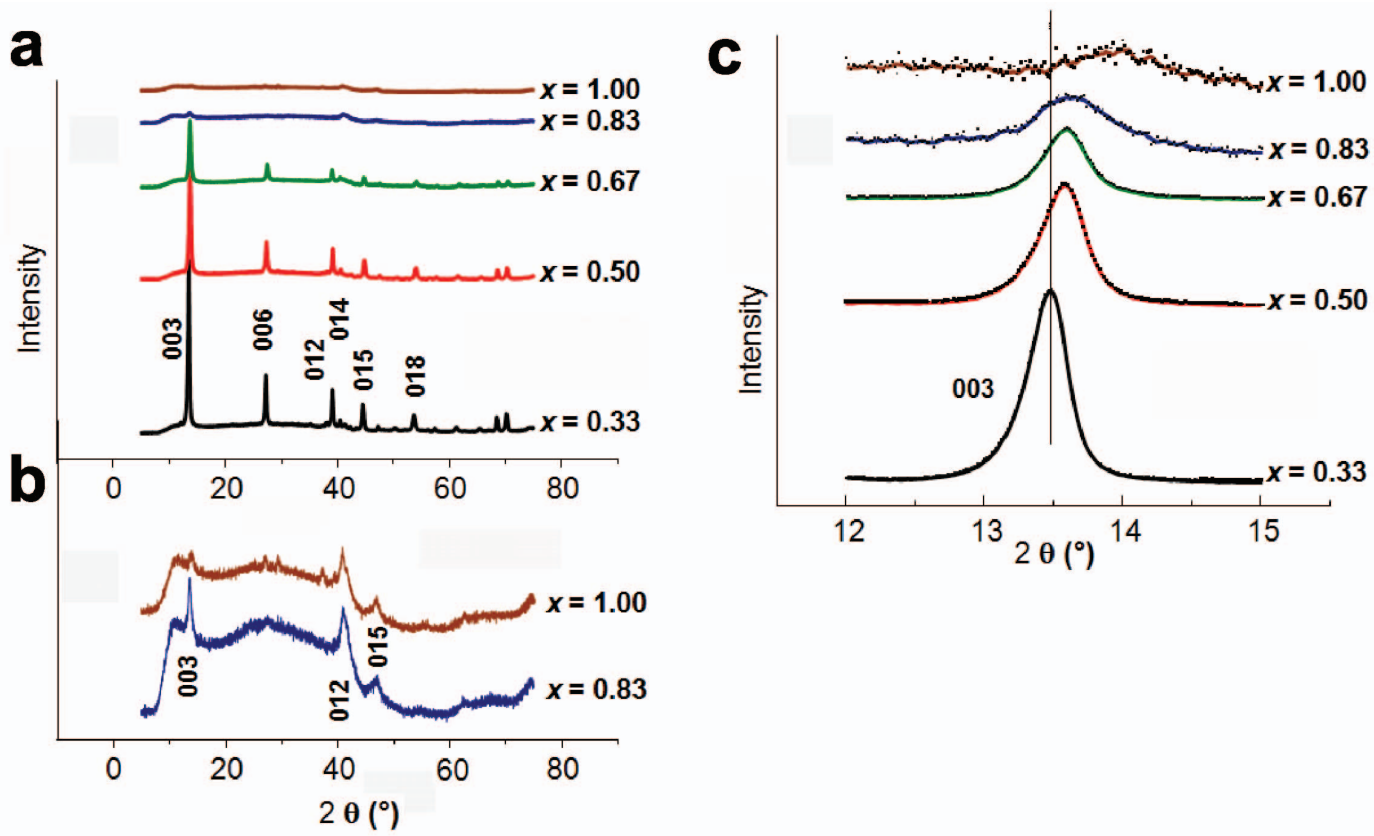

FIG. 10. The X-ray diffraction patterns of green rust samples during deprotonation, for $x=\left[\mathrm{Fe}^{3+}\right] /\left[\mathrm{Fe}_{\mathrm{tot}}\right]$ ranging from $1 / 3-1$. (a) All patterns using the same scale for intensity using CoK $\alpha$ radiation $(\lambda=1.7889 \AA)$; (b) details for $x=0.83$ and 1; and $(c)$ the (003) lines only, demonstrating the contraction of the lattice with $x$ and broadening due to the strain resulting from progressive deprotonation. Modified after Genin et al. (2012a).

rust related mineral was confirmed recently using XRD patterns of samples collected from groundwater from Bornholm, Denmark and Äspö, Sweden. The layer spacings $\left(d_{003}\right.$ in space group $R \overline{3} \mathrm{~m}$ ), were measured as 7.594 and $7.605 \AA$, which is consistent with synthetic samples with $x=$ $0.47-0.52$; i.e. fougèrite and trébeurdenite (Christiansen et al., 2009).
The magnetic properties of the fougèrite-group minerals arise from strong ordering of $\mathrm{Fe}^{3+}$ cations within individual layers for the specific values of $x=1 / 3,2 / 3$ and 1 (Rusch et al., 2008; Fig. 9). The two sublattices of $\mathrm{Fe}^{2+}$ and $\mathrm{Fe}^{3+}$ ions in the octahedral layer display an antiparallel coupling for $x=1 / 3$ and $2 / 3$, resulting in ferrimagnetic behaviour with Néel temperatures
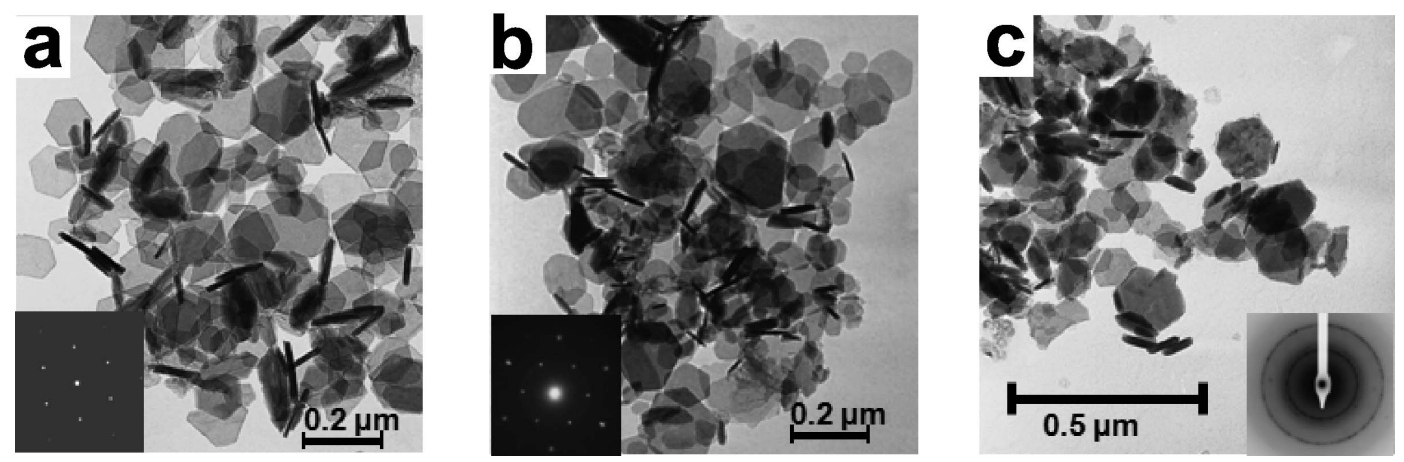

FIG. 11. Transmission electron micrographs of synthetic samples $(a) \mathrm{Fe}_{4}^{2+} \mathrm{Fe}_{2}^{3+}(\mathrm{OH})_{12} \mathrm{CO}_{3} \cdot 3 \mathrm{H}_{2} \mathrm{O}$ green rust with $x=$ $1 / 3,(b) x=1 / 2$ and (c) $\mathrm{Fe}_{6}^{3+} \mathrm{O}_{4}(\mathrm{OH})_{8} \mathrm{CO}_{3} \cdot 3 \mathrm{H}_{2} \mathrm{O}$ with $x=1$. Modified after Ruby et al. (2009). 
of $5 \mathrm{~K}$ and $\sim 20 \mathrm{~K}$, respectively. In contrast, material with $x=1$ is ferromagnetic with a Curie temperature $\sim 80 \mathrm{~K}$, and a broad range of transition. Although ordering of $\mathrm{Fe}^{2+}$ and $\mathrm{Fe}^{3+}$ restricts the composition of a given microscopic domain to $x=1 / 3, x=2 / 3$ and $x=1$, the topotactic intergrowth of such domains allows any intermediate value of $x$, as observed in natural and synthetic samples.

Figure 12 shows Mössbauer spectra obtained from natural gley samples fitted using Lorentzian line shapes. Figure $12 a$ displays the spectrum of a

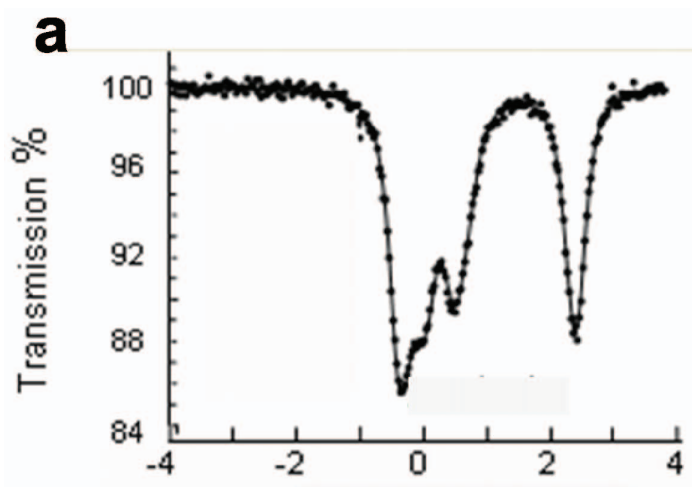

b
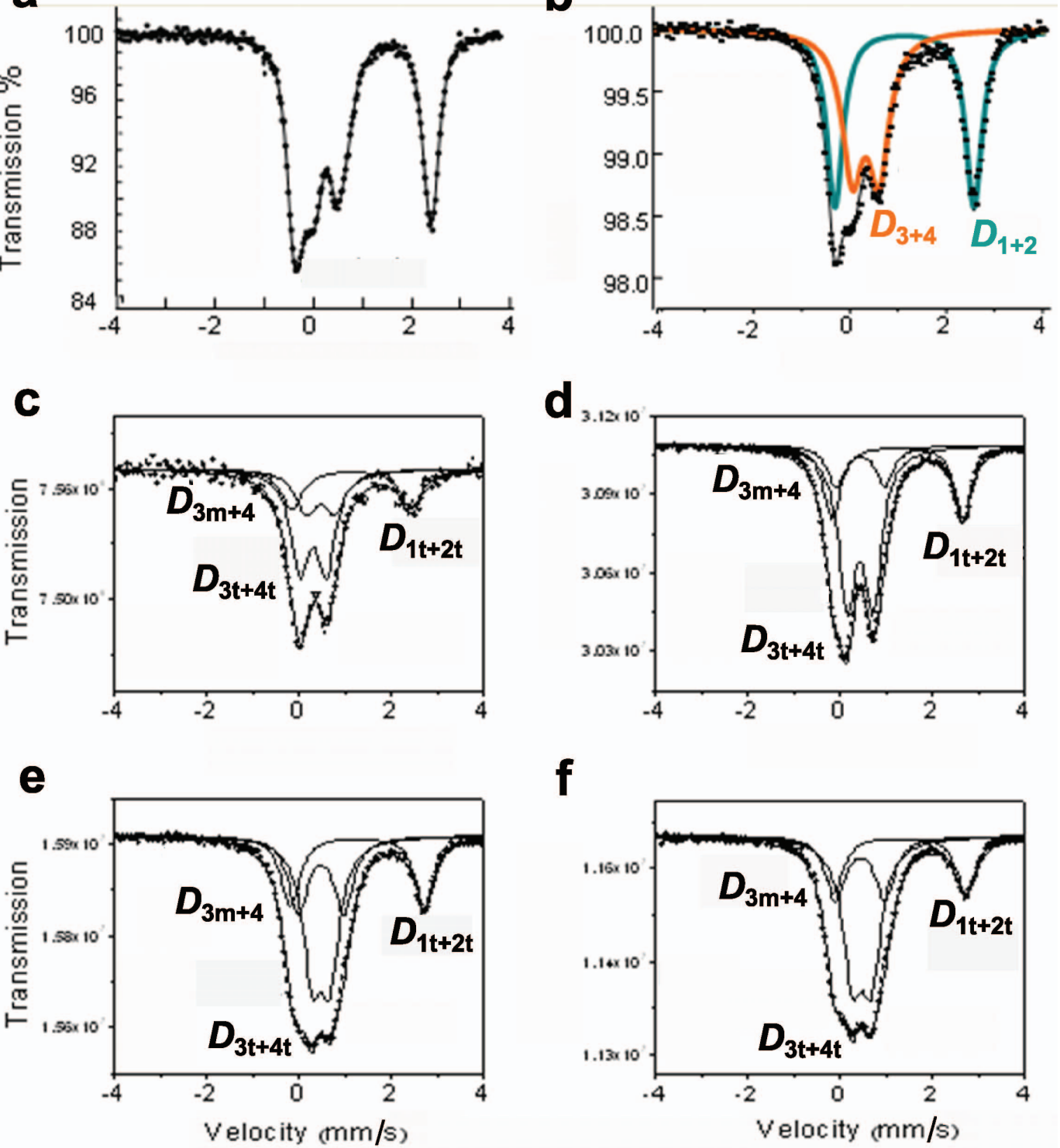

Fig. 12. Transmission Mössbauer spectra measured at $78 \mathrm{~K}$ of $(a)$ a synthetic sample of green rust with $x=0.50 ;(b)$ a sample of gley extracted from the aquifer at the forest of Fougères with $x=0.50 ;(c)$ room-temperature spectrum of a gley sample extracted from the shore of a salt marsh in Trébeurden with $x=0.75$; and $(d-f)$ spectra measured at $78 \mathrm{~K}$ of samples extracted from widely scattered locations in the Bay of Mont Saint-Michel with $x=0.72,0.74$ and 0.77, respectively. Modified after Genin et al. (2012a). 
synthetic sample with $x=1 / 2$, for comparison, and Fig. $12 b$ shows that of a sample collected from below the water table in the forest of Fougères; the spectra are nearly identical and, in both cases, only two quadrupole doublets are resolved. Figure $12 c-f$ displays the spectra of four samples extracted from maritime marshes; the first one from Trébeurden was measured at room temperature (Fig. 12c) and the three others extracted from the Bay of Mont Saint-Michel (Fig. 12d-f) at $78 \mathrm{~K}$. These spectra are qualitatively quite different from Fig. 12a,b. The Trébeurden spectrum shown in Fig. $12 c$ clearly resembles those of Fig. $12 d-f$ rather than Fig. 12a,b, despite the higher temperature of experimental measurement. The spectral resolution is somewhat poorer for natural samples compared to their synthetic counterparts, so a simpler method for fitting was employed, using a finite number of Lorentzian-shaped lines rather than Gaussian distributions of Lorentzians. In the range $1 / 3-2 / 3$, it was sufficient to use one broadened $\mathrm{Fe}^{2+}$ doublet as $D_{1 \mathrm{f}}, D_{2 \mathrm{f}}, D_{1 \mathrm{t}}$ and $D_{2 \mathrm{t}}$ could hardly be distinguished. In contrast, in the range $2 / 3-1$, three doublets were used: one $\mathrm{Fe}^{2+}$ doublet $\left(D_{1 \mathrm{t}}+D_{2 \mathrm{t}}\right)$, an $\mathrm{Fe}^{3+}$ doublet with a larger intensity representing $\left(D_{3 \mathrm{t}}+D_{4 \mathrm{t}}\right)$, and a doublet representing $\left(D_{3 \mathrm{~m}}+D_{4 \mathrm{~m}}\right)$, with a larger quadrupole splitting and broader linewidth. This simplified fitting procedure gave excellent results for spectra measured at $78 \mathrm{~K}$. Mössbauer parameters for spectra in Fig. $12 c-f$ are listed in Table 4.

The difference between the spectra of Fig. $12 a, b$ and Fig. $12 c-f$ arises because gleys from below the water table such as that of Fig. $12 b$ have $x$ in the $1 / 3-2 / 3$ range, whereas those from salt marshes have $x>2 / 3$. The salt marshes are covered by water only at high tide, so the gley is partially oxidized and reaches a steadystate $x$ value higher than that in permanently waterlogged aquifers. The samples extracted from Trébeurden and the Bay of Mont Saint- Michel all have $x=0.72-0.77$ according to the data of Table 4. The linear variation of intensities with composition is consistent with a mechanical mixture of different proportions of trébeurdenite and mössbauerite (Fig. 13).

It is possible to further decompose the partially resolved experimental doublet intensities into components that correspond to all the distinct $\mathrm{Fe}^{2+}$ and $\mathrm{Fe}^{3+}$ environments that are discussed above, if we note, consistent with the data of Tables 3 and 4, that: (1) total $D_{3 \mathrm{t}}+D_{3 \mathrm{~m}}$ is always $33.33 \%$; (2) the intensities of $D_{1 \mathrm{f}}: D_{2 \mathrm{f}}$ and $D_{1 \mathrm{t}}: D_{2 \mathrm{t}}$ are always in a $3: 1$ ratio; (3) the intensity ratio $D_{2 \mathrm{f}}: D_{3 \mathrm{f}}=1: 4$ and hence $\left(D_{1 \mathrm{f}}+D_{2 \mathrm{f}}\right)=D_{3 \mathrm{f}}=D_{4 \mathrm{f}}$; and (4) $D_{3 \mathrm{~m}}$ and $D_{4 \mathrm{~m}}$ are in a 1:2 ratio.

TABLE 4. Mössbauer parameters for quadrupole doublets in gley samples extracted from maritime marshes.

\begin{tabular}{|c|c|c|c|c|}
\hline \multicolumn{2}{|c|}{ Quadrupole doublet } & $\begin{array}{c}D_{1}+D_{2} \\
\mathrm{Fe}^{2+}(\mathrm{T})\end{array}$ & $\begin{array}{c}D_{3 \mathrm{t}}+D_{4 \mathrm{t}} \\
\mathrm{Fe}^{3+}(\mathrm{T})\end{array}$ & $\begin{array}{c}D_{3 \mathrm{~m}}+D_{4 \mathrm{~m}} \\
\mathrm{Fe}^{3+}(\mathrm{M})\end{array}$ \\
\hline \multicolumn{5}{|c|}{ Trébeurden room temperature } \\
\hline & $\delta\left(\mathrm{mm} \mathrm{s}^{-1}\right)$ & 1.294 & 0.301 & 0.307 \\
\hline \multirow[t]{3}{*}{$x=0.75$} & $\Delta\left(\mathrm{mm} \mathrm{s}^{-1}\right)$ & 2.66 & 0.549 & 0.972 \\
\hline & $R A(\%)$ & 25 & 50 & 25 \\
\hline & $\Gamma\left(\mathrm{mm} \mathrm{s}^{-1}\right)$ & 0.56 & 0.45 & 0.49 \\
\hline \multicolumn{5}{|c|}{ Mont Saint-Michel Bay $78 \mathrm{~K}$} \\
\hline No.1 & $\delta\left(\mathrm{mm} \mathrm{s}^{-1}\right)$ & 1.245 & 0.429 & 0.441 \\
\hline \multirow[t]{3}{*}{$x=0.72$} & $\Delta\left(\mathrm{mm} \mathrm{s}^{-1}\right)$ & 2.842 & 0.560 & 1.059 \\
\hline & $R A(\%)$ & 28 & 56 & 16 \\
\hline & $\Gamma\left(\mathrm{mm} \mathrm{s}^{-1}\right)$ & 0.45 & 0.49 & 0.50 \\
\hline No. 2 & $\delta\left(\mathrm{mm} \mathrm{s}^{-1}\right)$ & 1.263 & 0.471 & 0.470 \\
\hline \multirow[t]{3}{*}{$x=0.74$} & $\Delta\left(\mathrm{mm} \mathrm{s}^{-1}\right)$ & 2.908 & 0.381 & 0.986 \\
\hline & $R A(\%)$ & 26 & 52 & 22 \\
\hline & $\Gamma\left(\mathrm{mm} \mathrm{s}^{-1}\right)$ & 0.45 & 0.49 & 0.50 \\
\hline & $\delta\left(\mathrm{mm} \mathrm{s}^{-1}\right)$ & 1.292 & 0.466 & 0.434 \\
\hline \multirow{3}{*}{$x=0.77$} & $\Delta\left(\mathrm{mm} \mathrm{s}^{-1}\right)$ & 2.877 & 0.405 & 1.073 \\
\hline & $R A(\%)$ & 23 & 46 & 31 \\
\hline & $\Gamma\left(\mathrm{mm} \mathrm{s}^{-1}\right)$ & 0.45 & 0.49 & 0.50 \\
\hline
\end{tabular}




\section{HYDROTALCITE SUPERGROUP NOMENCLATURE}

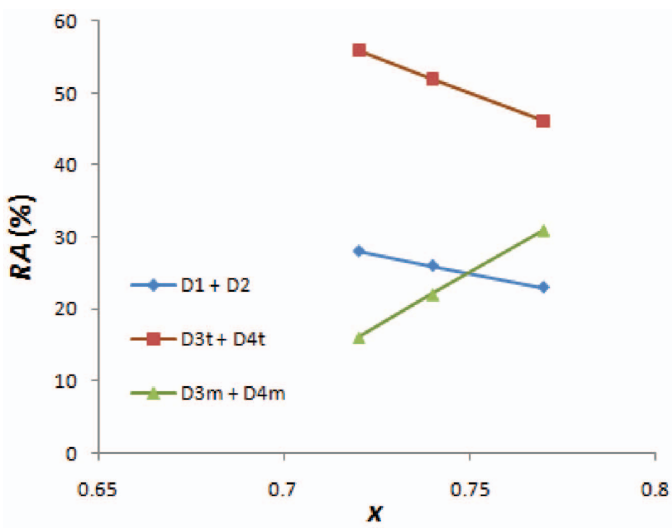

FIG. 13. Variation of relative areas for Mössbauer doublets $D_{1}+D_{2}, D_{3 \mathrm{t}}+D_{4 \mathrm{t}}$ and $D_{3 \mathrm{~m}}+D_{4 \mathrm{~m}}$ as a function of composition $x$ for the data of Table 4 .

Table 5 shows the results of this partitioning for the spectra of Fig. $12 c-f$ and Table 4, compared with the sample with the most similar composition from Fig. $7 h$ and Table 3. In the bottom four rows, the $D_{3}$ and $D_{4}$ peaks have been recombined according to the assignment schemes for both Table 3 and Table 4. It can be seen that the expected relative areas for the synthetic sample are within $2 \%$ of those given in Table 3, demonstrating that the site environment model, combined with the two doublet assignment schemes, applies to datasets from both the synthetic and natural samples, despite the use of different peak-fitting methodologies. Figure 14 shows the relative proportions for $D_{1}-D_{4}$ sites as a function of bulk composition for $x$ in the range $1 / 3-1$.

As there are distinct variants of $D_{1}$ and $D_{2}$ for fougèrite and trébeurdenite, and similarly, three versions of $D_{3}$ and two of $D_{4}$, there are nine Fe environments in total in the three minerals. The cation ordering patterns of Fig. 9 allow us to determine the identities of edge-sharing neighbour cations. As discussed above, the $D_{3} \mathrm{Fe}^{3+}$ of fougèrite, i.e. $D_{3 \text { f }}$, are obviously situated above and below interlayer carbonate anions, to facilitate charge balance. The constant proportion of $D_{3}$ cations in all three minerals confirms that this situation is maintained in each species, in which case the ordering patterns of Fig. 15 can be deduced for the site types $D_{1}-D_{4}$. If the $\mathrm{O}^{2-}$ anions in the hydroxide sublayer, produced by dehydroxylation, are required to be bonded to $D_{4}$ cations, the local environments around the Fe sites can be characterized as in Table 6. The distributions of these sites between the three species are summarized in Table 7.

Given that intermediate compositions are intergrowths of the phases with $x=1 / 3,2 / 3$ or 1 , any sample in the range $1 / 3-2 / 3$ is a mixture of fougèrite $(F)$ and trébeurdenite $(T)$, with proportions obtained by the lever rule $(2-3 x) F+(3 x-1) T$, whereas compositions in the range $2 / 3-1$ are

TABLE 5. Expected relative abundances of distinct Fe cation environments corresponding to the Mössbauer spectra of Fig. $12 c-f$ and Table 4, with the $x=0.78$ synthetic specimen of Fig. $7 h$ and Table 3 for comparison.

\begin{tabular}{|c|c|c|c|c|c|}
\hline & Trébeurden & $\begin{array}{l}\text { Mont St Michel } \\
\text { no.1 }\end{array}$ & $\begin{array}{c}\text { Mont St Michel } \\
\text { no.2 }\end{array}$ & $\begin{array}{c}\text { Mont St Michel } \\
\text { no.3 }\end{array}$ & Synthetic \\
\hline$x$ & 0.75 & 0.72 & 0.74 & 0.77 & 0.78 \\
\hline$T$ (mol.\%) & 75 & 84 & 78 & 69 & 66 \\
\hline$M(\mathrm{~mol} . \%)$ & 25 & 16 & 22 & 31 & 34 \\
\hline$D_{1 \mathrm{t}}(\%)$ & 18.75 & 21 & 19.5 & 17.25 & 16.5 \\
\hline$D_{2+}(\%)$ & 6.25 & 7 & 6.5 & 5.75 & 5.5 \\
\hline$D_{3 \mathrm{t}}(\%)$ & 25 & 28 & 26 & 23 & 22 \\
\hline$D_{4 \mathrm{t}}(\%)$ & 25 & 28 & 26 & 23 & 22 \\
\hline$D_{3 \mathrm{~m}}(\%)$ & 8.33 & 5.33 & 7.33 & 10.33 & 11.33 \\
\hline$D_{4 \mathrm{~m}}(\%)$ & 16.67 & 10.67 & 14.67 & 20.67 & 22.67 \\
\hline$D_{3 \mathrm{t}}+D_{3 \mathrm{~m}}$ & 33.33 & 33.33 & 33.33 & 33.33 & 33.33 \\
\hline$D_{4 \mathrm{t}}+D_{4 \mathrm{~m}}$ & 33.33 & 38.67 & 40.67 & 43.67 & 44.67 \\
\hline$D_{3 \mathrm{t}}+D_{4 \mathrm{t}}$ & 50 & 56 & 52 & 46 & 44 \\
\hline$D_{3 \mathrm{~m}}+D_{4 \mathrm{~m}}$ & 25 & 16 & 22 & 31 & 34 \\
\hline
\end{tabular}




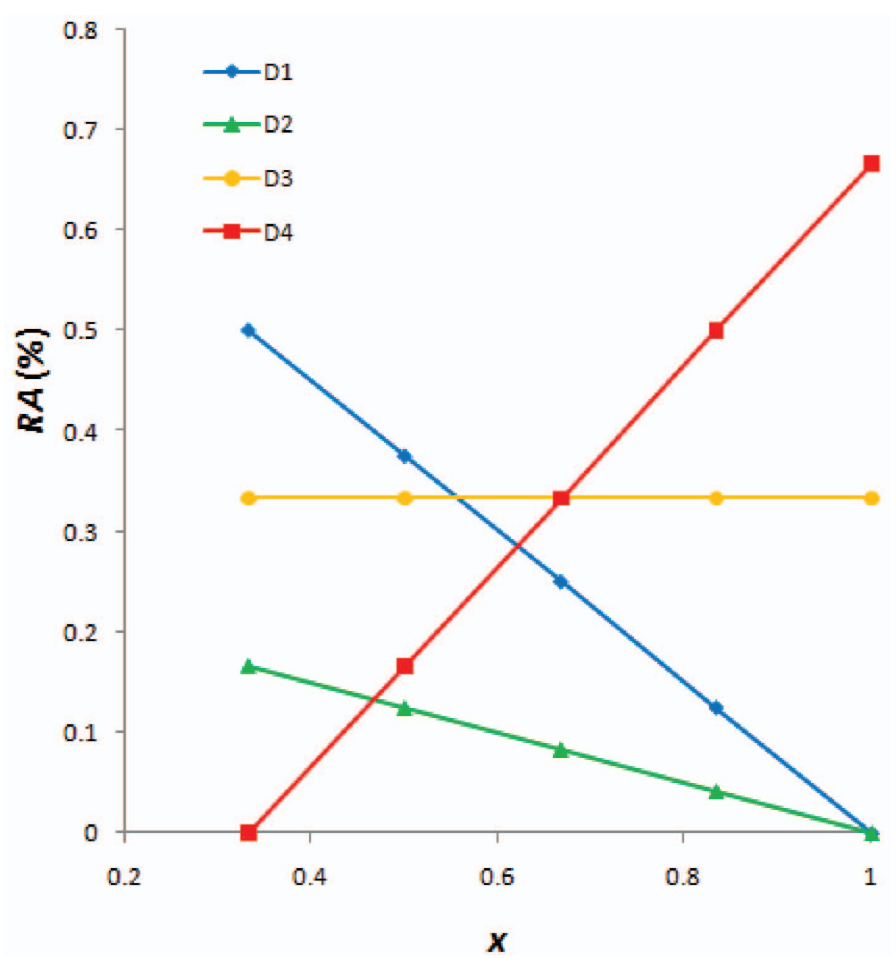

FIG. 14. Relative abundance of Fe cation environments $D_{1}-D_{4}$ as a function of bulk composition.

mixtures of $T$ and mössbauerite $(M)$ with the proportions $3(1-x) T+(3 x-2) M$. To date, occurrences of gleys extracted from continental aquifers as at Fougères only have compositions in the range $x=1 / 3-2 / 3$, whereas those from salt marsh environments such as Trébeurden or Mont<smiles>O=C(O)OC(=O)O[Na]</smiles>

000

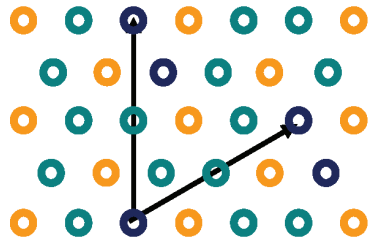

$$
\begin{gathered}
F \\
D_{1 \mathrm{f}}=1 / 1 / 2 ; D_{2 \mathrm{f}}=1 / 6 \\
D_{3 \mathrm{f}}=1 / 3
\end{gathered}
$$
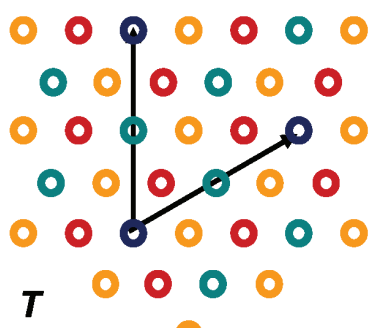

$$
\begin{aligned}
& D_{1 \mathrm{t}}=1 / 4 ; D_{2 \mathrm{t}}=1 / 12 \\
& D_{3 \mathrm{t}}=1 / 3 ; D_{4 \mathrm{t}}=1 / 3
\end{aligned}
$$

$D_{3}$

$D_{4}$

FIG. 15. Cations in the octahedral layer of fougèrite $(F)$, trébeurdenite $(T)$ and mössbauerite $(M)$, showing the twodimensional superstructures that arise if $\mathrm{Fe}^{2+}$ and $\mathrm{Fe}^{3+}$ order as in Fig. 9 and $D_{2}$ and $D_{3}$ environments which are clustered near interlayer carbonate. Arrows indicate vectors between equivalent $\mathrm{Fe}$ sites. 
TABLE 6. Details of the local environments for Fe cations.

\begin{tabular}{lcccc}
\hline $\begin{array}{l}\text { Local } \\
\text { environment type }\end{array}$ & Cation & $\begin{array}{c}\text { Edge-sharing } \\
\text { octahedral neighbours }\end{array}$ & $\begin{array}{c}\text { Interlayer species in } \\
\text { vertical registry }\end{array}$ & $\begin{array}{c}\text { Ligands in } \\
\text { octahedral layer }\end{array}$ \\
\hline$D_{1 \mathrm{f}}$ & $\mathrm{Fe}^{2+}$ & $3 \mathrm{Fe}^{2+}+3 \mathrm{Fe}^{3+}$ & $\mathrm{H}_{2} \mathrm{O}$ & $(\mathrm{OH})_{6}$ \\
$D_{2 \mathrm{f}}$ & $\mathrm{Fe}^{2+}$ & $3 \mathrm{Fe}^{2+}+3 \mathrm{Fe}^{3+}$ & $\mathrm{CO}_{3}^{2-}$ & $(\mathrm{OH})_{6}$ \\
$D_{3 \mathrm{f}}$ & $\mathrm{Fe}^{3+}$ & $6 \mathrm{Fe}^{2+}$ & $\mathrm{CO}_{3}^{2-}$ & $(\mathrm{OH})_{6}$ \\
$D_{1 \mathrm{t}}$ & $\mathrm{Fe}^{2+}$ & $6 \mathrm{Fe}^{3+}$ & $\mathrm{H}_{2} \mathrm{O}$ & $(\mathrm{OH})_{6}$ \\
$D_{2 \mathrm{t}}$ & $\mathrm{Fe}^{2+}$ & $6 \mathrm{Fe}^{3+}$ & $\mathrm{CO}_{3}^{2-}$ & $(\mathrm{OH})_{6}$ \\
$D_{3 \mathrm{t}}$ & $\mathrm{Fe}^{3+}$ & $3 \mathrm{Fe}^{2+}+3 \mathrm{Fe}^{3+}$ & $\mathrm{CO}_{3}^{2-}$ & $(\mathrm{OH})_{5} \mathrm{O}$ \\
$D_{4 \mathrm{t}}$ & $\mathrm{Fe}^{3+}$ & $3 \mathrm{Fe}^{2+}+3 \mathrm{Fe}^{3+}$ & $\mathrm{H}_{2} \mathrm{O}$ & $(\mathrm{OH})_{4} \mathrm{O}_{2}$ \\
$D_{3 \mathrm{~m}}$ & $\mathrm{Fe}^{3+}$ & $6 \mathrm{Fe}^{3+}$ & $\mathrm{CO}_{3}^{2-}$ & $(\mathrm{OH})_{4} \mathrm{O}_{2}$ \\
$D_{4 \mathrm{~m}}$ & $\mathrm{Fe}^{3+}$ & $6 \mathrm{Fe}^{3+}$ & $\mathrm{H}_{2} \mathrm{O}$ & $(\mathrm{OH})_{4} \mathrm{O}_{2}$ \\
\hline
\end{tabular}

Saint-Michel Bay only have compositions in the range $x=2 / 3-1$.

Based on the data and analysis outlined in the foregoing text:

(1) We redefine the former 'fougèrite', which was named for its occurrence in forest of Fougères by Trolard et al. (2007), as a $\mathrm{Fe}^{2+}-\mathrm{Fe}^{3+}$ hydroxycarbonate with the formula $\mathrm{Fe}_{4}^{2+} \mathrm{Fe}_{2}^{3+}(\mathrm{OH})_{12} \mathrm{CO}_{3} \cdot 3 \mathrm{H}_{2} \mathrm{O}$, and with $x=1 / 3$; it is the common $\mathrm{Fe}^{2+}-\mathrm{Fe}^{3+} \mathrm{LDH}$, and is commonly described as 'green rust' or 'carbonated green rust.' Note that the artificial equivalent of carbonated green rust commonly forms during the corrosion of Fe-based materials and steels (e.g. Drissi et al., 1995).

(2) We define the $\mathrm{Fe}^{2+}-\mathrm{Fe}^{3+}$ oxyhydroxycarbonate with $x=2 / 3$, and with the formula $\mathrm{Fe}_{2}^{2+} \mathrm{Fe}_{4}^{3+} \mathrm{O}_{2}(\mathrm{OH})_{10} \mathrm{CO}_{3} \cdot 3 \mathrm{H}_{2} \mathrm{O}$, as trébeurdenite; it is named for the township of Trébeurden, near the maritime marsh where the mineral was first found. The holotype specimen M52133 is accessioned in the collections of Museum Victoria in Melbourne, and is from l'Île d'Aval, near Penvern, Trébeurden, Brittany, France.

(3) The ferric oxyhydroxycarbonate with $x=1$ and the formula $\mathrm{Fe}_{6}^{3+} \mathrm{O}_{4}(\mathrm{OH})_{8} \mathrm{CO}_{3} \cdot 3 \mathrm{H}_{2} \mathrm{O}$ is named mössbauerite, after Professor Rudolf Mössbauer (1928-2011) who discovered the resonance of $\gamma$ rays that bears his name, for which he was awarded the 1961 Nobel Prize in physics. The full type description of mössbauerite is reported in Génin et al. (2012b).

\section{Group nomenclature}

Group nomenclature for the hydrotalcite supergroup follows the CNMNC guidelines outlined by Mills et al. (2009). The group nomenclature scheme discussed here can be considered as a hybrid, in that the groups are defined firstly by the interlayer spacing and secondly by the $\mathrm{M}^{2+}: \mathrm{M}^{3+}$ ratios in the brucite layers. The restricted ranges found for those ratios in many members of the supergroup suggest that they correlate with cation ordering patterns within layers, which may or may not correlate between layers, as evidenced by diffraction behaviour. The dominant $M^{2+}$ and $M^{3+}$ cations are important for defining individual species based on the dominant-constituent and dominant-valency rules (Hatert and Burke, 2008). Due to the differences in the ionic radii of the $M^{2+}$ and $M^{3+}$ cations in some of the minerals (e.g. in

TABLE 7. Abundance of different local Fe environments in the green rust minerals.

\begin{tabular}{|c|c|c|c|c|c|c|c|c|c|}
\hline & $\overline{D_{1 \mathrm{f}}}$ & $\bar{D}_{1 \mathrm{t}}$ & $\overline{D_{2 \mathrm{f}}}$ & $\bar{D}_{2 \mathrm{t}}$ & $D_{3 \mathrm{f}}$ & $\begin{array}{r}-D_{3} \\
D_{3 \mathrm{t}}\end{array}$ & $D_{3 \mathrm{~m}}$ & $D_{4 \mathrm{t}}$ & $\bar{D}_{4 \mathrm{~m}}$ \\
\hline $\begin{array}{l}\text { Fougèrite } \\
\text { Trébeurdenite } \\
\text { Mössbauerite }\end{array}$ & $50 \%$ & $25 \%$ & $16.7 \%$ & $8.3 \%$ & $33.3 \%$ & $33.3 \%$ & $33.3 \%$ & $33.3 \%$ & $66.7 \%$ \\
\hline
\end{tabular}


the hydrotalcite group), specific $M^{2+}: M^{3+}$ ratios are strongly favoured (e.g. 2:1). In other groups, where the ionic radii are very similar (e.g. in the woodwardite group), there may be wide variation in $M^{2+}: M^{3+}$ ratios within and between species.

The following groups (in order of the smallest to largest interlayer periodicity) can be defined:

(1) Hydrotalcite group: hydrotalcite group members have an $M^{2+}: M^{3+}$ ratio of $3: 1$, they contain interlayer carbonate, chloride or hydroxide and water, and have a layer spacing of $\sim 7.8 \AA$.

(2) Quintinite group: quintinite group members have an $M^{2+}: M^{3+}$ ratio of $2: 1$, they contain interlayer carbonate or chloride and water, and have a layer spacing of $\sim 7.8 \AA$.

(3) Fougèrite group: the 'green rusts' of the fougèrite group have a layer spacing of $\sim 7.8 \AA$; they are not included in either of the groups listed above because the dominant octahedral cations, either $\mathrm{Fe}^{2+}$ or $\mathrm{Fe}^{3+}$, are readily interconverted by redox processes. Two members of the group, trébeurdenite and mössbauerite, provide the only examples of $M^{3+}$ dominance in the hydrotalcite supergroup, and contain some $\mathrm{O}^{2-}$ in replacement of $\mathrm{OH}^{-}$.

(4) Woodwardite group: minerals of the woodwardite group are characterized by the presence of interlayer sulfate and water, and have a layer spacing of $\sim 8.9 \AA$. The $M^{2+}: M^{3+}$ ratio is variable in members of the group and no evidence of cation ordering has been reported. The layer spacing is greater than hydrotalcite and quintinite due to the size of the sulfate tetrahedra. These compounds also differ from the hydrotalcite and quintinite groups in showing a marked preference for the small $M^{2+}$ cations $\mathrm{Ni}, \mathrm{Cu}$ and $\mathrm{Zn}$ rather than $\mathrm{Mg}, \mathrm{Mn}$ and $\mathrm{Fe}$. Furthermore, the woodwardite group minerals readily and reversibly undergo transformations to the more highly hydrated minerals of the glaucocerinite group by intercalation of additional interlayer water molecules.

(5) Cualstibite group: members of the cualstibite group are characterized by $\left(\mathrm{M}^{2+}\right.$, $\left.M^{3+}\right)(\mathrm{OH})_{2}$ brucite-type sheets, in which $M^{2+}$, $\mathrm{Cu}^{2+}, \mathrm{Ni}^{2+}$ or $\mathrm{Zn}^{2+}, M^{3+}=\mathrm{Al}^{3+}$ or $\mathrm{Fe}^{3+}$, and the interlayer species is $\left[\mathrm{Sb}(\mathrm{OH})_{6}\right]^{-}$. The layer spacing is $\sim 9.7 \AA$.

(6) Glaucocerinite group: glaucocerinite group members are characterized by the presence of interlayer sulfate and water, and less commonly non-essential intercalated $\mathrm{M}^{2+}$ cations where $\mathrm{M}^{2+}$ $=\mathrm{Mg}^{2+}$ or $\mathrm{Ni}^{2+}$. The layer spacing is $\sim 11 \AA$, and the interlayers contain additional water in comparison to members of the woodwardite group. The $M^{2+}: M^{3+}$ ratios are variable.

(7) Wermlandite group: wermlandite group members are characterized by the presence of interlayer sulfate, water and essential $\left[A\left(\mathrm{H}_{2} \mathrm{O}\right)_{6}\right]$ groups, where $A=\mathrm{Na}^{+}, \mathrm{Ca}^{2+}, \mathrm{Sr}^{2+}$, or similarly large cations. The layer spacing is $\sim 11 \AA$ and $M^{2+}: M^{3+}$ ratios are variable.

(8) Hydrocalumite group: hydrocalumite group members contain $(\mathrm{Ca}, \mathrm{Al})(\mathrm{OH})_{2}$ sheets in which the $\mathrm{Ca}: \mathrm{Al}$ ratio is always $2: 1 ; \mathrm{Ca}^{2+}$ is coordinated to a seventh ligand of 'interlayer' water. They may contain interlayer hydroxyl, carbonate, chloride or sulfate and water.

The members of these groups are listed in Table 8. Table 9 includes the ideal simplified formulae for the species listed in Table 8 , as derived earlier in the discussion of individual species. These formulae are compared with those given in the 2009 IMA mineral list, which are available at http://pubsites.uws.edu.au/imacnmnc/IMA2009-01 UPDATE 160309.pdf.

\section{Unnamed minerals}

\section{Unnamed $\mathrm{Co}^{3+}$ analogue of reevesite}

Song and Moon (1998) reported 'reevesite' from serpentinized ultramafic rocks of the Kwangcheon area in Korea, which showed solid solution almost all the way to the $\mathrm{Co}^{3+}$ endmember, and verified the completeness of the solid solution by syntheses. The Co-dominant synthetic material is dark green in colour in comparison to the yellow-brown of synthetic reevesite. The $\mathrm{Ni}^{2+} /\left(\mathrm{Fe}^{3+}+\mathrm{Co}^{3+}\right)$ ratio was reported to be close to $3: 1$, which is typical of the hydrotalcite group and contrasts with the 2:1 ratio reported for comblainite (Piret and Deliens, 1980). The new mineral has not yet been fully described or submitted to the IMA for approval. The phase was given the unnamed mineral code UM199810-CO:CoHNi by Smith and Nickel (2007).

\section{Unnamed Mg-Al analogue of honessite}

Lisitsina et al. (1985) described a Mg-Al sulfate from a North Atlantic seamount with $a=3.05$ and $c=26.50=3 \times 8.83 \AA$. Bookin et al. (1993a) discussed attempts to fit the X-ray intensity data, and concluded that the phase had the unusual $3 T_{2}$ stacking sequence. An intergrown 2-layer structure was also detected, but the diffraction data were not sufficient for more detailed characterization. In contrast, the synthetic 
TABLE 8. Group hierarchy of the hydrotalcite supergroup.

\section{HYDROTALCITE SUPERGROUP}

\section{Hydrotalcite group}

Hydrotalcite, Pyroaurite, Stichtite, Meixnerite, Iowaite, Droninoite, Woodallite, Desautelsite,

Takovite, Reevesite, Jamborite*

\section{Quintinite group}

Quintinite, Charmarite, Caresite, Zaccagnaite, Chlormagaluminite, Comblainite

Fougèrite group

Fougèrite, Trébeurdenite, Mössbauerite

\section{Woodwardite group}

Woodwardite, Zincowoodwardite, Honessite

\section{Glaucocerinite group}

Glaucocerinite, Hydrowoodwardite, Carrboydite*, Hydrohonessite, Mountkeithite, Zincaluminite*

\section{Wermlandite group}

Wermlandite, Shigaite, Nikischerite, Motukoreaite*, Natroglaucocerinite*, Karchevskyite

\section{Cualstibite group}

Cualstibite, Zincalstibite, Omsite

\section{Hydrocalumite group}

Hydrocalumite, Kuzelite

\section{Unclassified}

Coalingite, Brugnatellite*, Muskoxite*

\footnotetext{
* Questionable species which need further study.
}

$\mathrm{Mg}_{6} \mathrm{Al}_{2}(\mathrm{OH})_{16}\left(\mathrm{SO}_{4}\right) \cdot n \mathrm{H}_{2} \mathrm{O}$ of Miyata and Okada (1977) with $a=3.05$ and $c=25.97 \AA$, has the $3 R_{1}$ structure according to Bookin et al. (1993a).

\section{Unnamed Mg analogue of carrboydite or Al analogue of mountkeithite}

Lisitsina et al. (1985) reported a second $\mathrm{Mg}-\mathrm{Al}$ sulfate from the North Atlantic seamount described in the foregoing text, with $c=32.4=$ $3 \times 10.8 \AA$, for which Bookin et al. $(1993 a)$ deduced the $3 R_{1}$ stacking sequence. Drits et al. (1987) described a similar phase with the formula $\mathrm{Mg}_{4} \mathrm{Al}_{2}(\mathrm{OH})_{12}\left(\mathrm{SO}_{4}\right) \cdot n \mathrm{H}_{2} \mathrm{O}$ from Gaurdak, Turkmenistan, but this has $c=11.16 \AA$, and hence is the $1 T$ polytype.

\section{Unnamed $M g-A l$ interstratified sulfate-carbonate}

Drits et al. (1987) described a phase with the formula $\mathrm{Mg}_{4} \mathrm{Al}_{2}(\mathrm{OH})_{12}\left(\mathrm{CO}_{3}\right)_{0.5}\left(\mathrm{SO}_{4}\right)_{0.5} \cdot n \mathrm{H}_{2} \mathrm{O}$, from the Inder salt dome, Caspian Depression, Kazakhstan. It has a unit cell with $a=3.05$ and $c=55.62=3 \times 18.54 \AA$ A. Bookin et al. $(1993 a)$ interpreted the $18.54 \AA$ spacing as the sum of a narrow $6.56 \AA$ layer spacing corresponding to interlayer carbonate, and a wide $9.98 \AA$ spacing corresponding to interlayer sulfate, implying a regular alternation of two types of interlayer in the structure. They suggested that the narrow interlayers were $P$-type and the wide ones $O$ type, corresponding to the unusual $6 R_{4}$ stacking sequence overall.

\section{Unnamed hydroxide analogue of coalingite}

The 'coalingite' from the Muskox Intrusion, Canada, described by Jambor (1969a) was reported to have a very low carbonate content, and a formula (based on 12 cations) $\left[\left(\mathrm{Mg}_{9.67} \mathrm{Fe}_{2.33}^{3+}(\mathrm{OH})_{24}\right]\left(\mathrm{CO}_{3}\right)_{0.33}(\mathrm{OH})_{1.67} \cdot 1.75 \mathrm{H}_{2} \mathrm{O}\right.$. This was discussed further by Pastor-Rodriguez and Taylor (1971). The material is trigonal with $a$ $=3.1 \AA$; $c$ is uncertain but $>30 \AA$. This phase may be the hydroxide analogue of coalingite, but requires further investigation. 
S. J. MILLS ET AL.

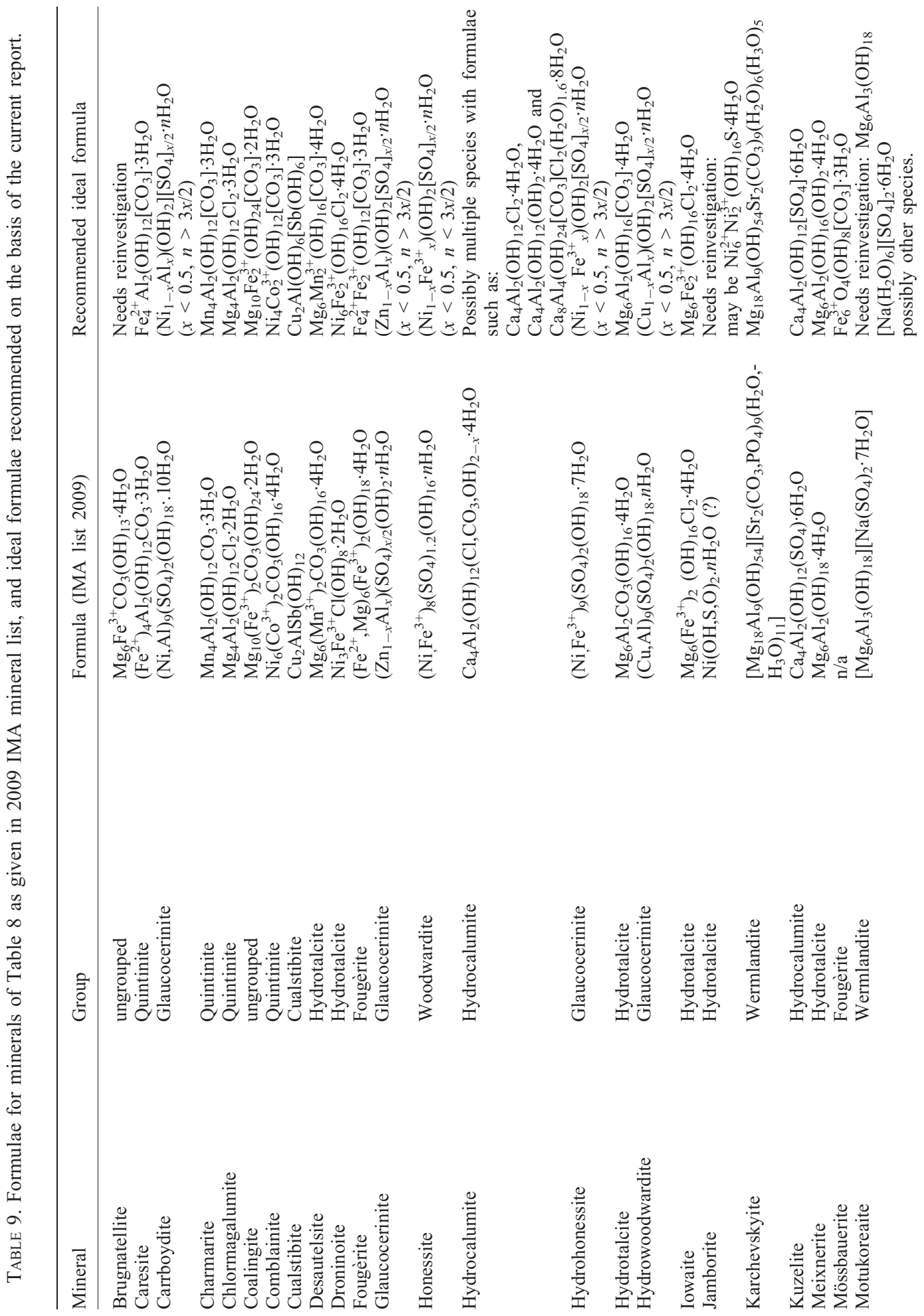



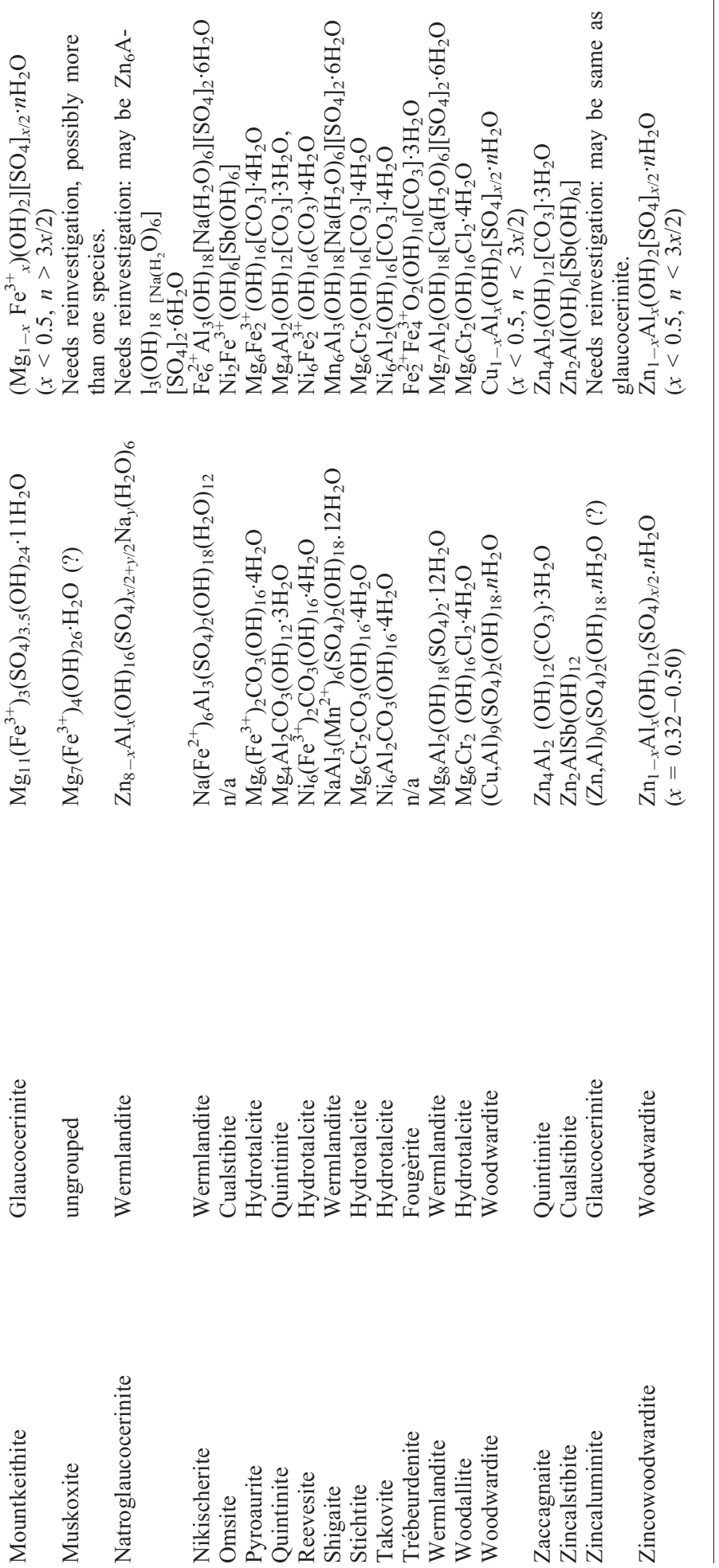


\section{'Coalingite-K'}

Mumpton et al. (1965) reported a second phase occurring in parallel intergrowth with coalingite, which was different in its optical and diffraction properties. This material was re-examined by Pastor-Rodriguez and Taylor (1971), who interpreted strong diffraction features at 5.72 and $4.38 \AA$ as (0003) and (0004) reflections corresponding to a $17.2 \AA \mathrm{c}$ repeat, and hypothesized that the phase was an interstratification of three brucite layers and one interlayer, forming a polysomatic series with brucite, coalingite and pyroaurite. The ideal formula, in this case, would be $\left[\mathrm{Mg}_{16} \mathrm{Fe}_{2}^{3+}(\mathrm{OH})_{36}\right]\left(\mathrm{CO}_{3}\right) \cdot 2 \mathrm{H}_{2} \mathrm{O}$, but this has not been verified, and the mineral has not been studied further or submitted for approval by the IMA.

\section{Unnamed $\mathrm{Mg}^{2+}-\mathrm{Ni}^{3+}$ hydroxide}

A mineral described by Lapham (1965) from the Cedar Hill serpentinite quarry, Lancaster County, Pennsylvania is rhombohedral with $a=3.12$ and $c=23.19 \AA$, which suggests a $3 R$ polytype related to the hydrotalcite and quintinite groups. Carbonate is low or absent. The atomic $\mathrm{Mg}: \mathrm{Ni}: \mathrm{Fe}$ ratio was reported to be $80.8: 15.0: 4.2$, implying that, at most, $1 / 5.3$ of the octahedral cations is trivalent $(\mathrm{Ni}+\mathrm{Fe})$. This incompletely described phase may be a $\mathrm{Mg}^{2+}-\mathrm{Ni}^{3+}$-hydroxide analogue of brugnatellite. The phase was given the unnamed mineral code UM1965-08$\mathrm{OH}: \mathrm{FeMgNi}$ by Smith and Nickel (2007).

\section{Unnamed $\mathrm{Ni}^{2+}-\mathrm{Ni}^{3+}$ hydroxide}

A nickel-rich mineral described by Jambor and Boyle (1964) from Rock Creek, British Columbia, Canada is rhombohedral with $a=3.07$ and $c=$ $22.74 \AA$, indicating that it is a $3 R$ polytype related to the hydrotalcite and quintinite groups. Carbonate is low or absent and the $\mathrm{Mg}$ content is also negligible. The phase was compared by Lapham (1965) with his Mg-rich phase and to various synthetic compounds. This incompletely described phase may be a $\mathrm{Ni}^{2+}-\mathrm{Ni}^{3+}$-hydroxide analogue of hydrotalcite, quintinite or brugnatellite.

\section{Nomenclature for synthetic LDH phases}

Many synthetic LDH phases have a similar crystallography and chemistry to natural phases; however, a much wider range of octahedral cations and intercalcated anions have been incorporated in synthetic LDH compounds. Unfortunately, some chemists have tended to use mineral names incorrectly in referring to synthetic analogues of minerals and their structural relatives. As a result of this, and due to the inconsistencies in reporting and naming synthetic LDH phases, we propose a simple but flexible nomenclature scheme which can be applied to synthetic phases; it provides information about the chemistry and crystallography of the phase and also clearly identifies it as a synthetic compound. Such a scheme would only become best practice among chemists if it was adopted by the International Union for Pure and Applied Chemistry, but as informal nomenclature schemes are already being used in the synthetic LDH literature, we can at least offer a consistent and rational alternative to the misuse of mineral names.

Hydrotalcite-like Mg-Al LDHs can be prepared by mixing aqueous solutions of alkalis such as $\mathrm{NaOH}$ with $\mathrm{Mg}-\mathrm{Al}$ solutions such as $\mathrm{MgCl}_{2}-\mathrm{AlCl}_{3}$ and $\mathrm{Mg}\left(\mathrm{NO}_{3}\right)_{2}-\mathrm{Al}\left(\mathrm{NO}_{3}\right)_{3}$ (e.g. Ross and Kodama, 1967; Miyata, 1975; Miyata and Okada, 1977). The stoichiometric equation describing the precipitation of synthetic $\mathrm{Mg}-\mathrm{Al}$ LDHs, for example, can be written:

$$
\begin{aligned}
(1-x) \mathrm{Mg}^{2+}+x \mathrm{Al}^{3+}+2 \mathrm{OH}^{-}+ & (x / n) A^{n-} \rightarrow \\
& \operatorname{Mg}_{1-x} \mathrm{Al}_{x}(\mathrm{OH})_{2}(A)_{x / n}
\end{aligned}
$$

where $0.20 \leqslant x \leqslant 0.33$ and $A^{n-}$ is an $n$-valent anion. The $\mathrm{Mg} / \mathrm{Al}$ molar ratio $x$ and anion $A^{n-}$ can be controlled during preparation of the LDH and need to be specified in the nomenclature scheme. Our proposal for a nomenclature system for synthetic LDH phases uses the following formula: LDH $x M^{2+} y M^{3+} \cdot A[B]-C$, where $x$ and $y$ are the proportions of $M^{2+}$ and $M^{3+} ; M^{2+}$ is the divalent cation in the octahedral layer; $M^{3+}$ is the trivalent cation in the octahedral layer; $A$ is the intercalated anion; $B$ is an interlayer cation; and $C$ is the polytype symbol.

If this scheme is adopted the following guidelines can usefully be applied:

(1) If there are no interlayer $B$ cations, the associated brackets '[ ]' can be omitted.

(2) It is the ratio $x: y$ which is important rather than the absolute values of $x$ and $y$ themselves, as is the case for any empirical formula. Thus, ' $6 \mathrm{Mg} 2 \mathrm{Al}$ ' is equivalent to ' $75 \mathrm{Mg} 25 \mathrm{Al}$ ' in this scheme; however, ' 1 ' is optional, as in chemical formulae, so ' $3 \mathrm{Mg} 1 \mathrm{Al}$ ' could be shortened to ' $3 \mathrm{MgAl}$ '. 
(3) The different hydration states of the analogues of woodwardite- and glaucocerinitegroup minerals are not explicitly distinguished, but such phases are likely to be rapidly and reversibly convertible.

(4) The polytype symbol $C$ conveys the overall number of brucite layers in the repeat, and the overall crystal system/lattice type. If one of the precise stacking sequences for brucite layers of Table 1 is known and needs to be specified, numerical subscripts can be added. If a distinction between types of stacking that arise by different structural mechanisms (cf. discussion of quintinite and wermlandite) is required, extensions to the notation will be needed.

(5) It is assumed that there is only one type of interlayer. Interstratified structures such as that of coalingite are not provided for in the basic notation, although Bookin et al. (1993a) suggest a notation for encoding this information.

Given the fast crystallization kinetics of synthetic LDH phases, it is likely that the octahedral cation site or interlayer site occupancy patterns will not display long-range order of the types considered in points (3) and (4) above, so more complex notation is probably not necessary.

As examples of the notation, the mineral pyroaurite has the formula $\mathrm{Mg}_{6} \mathrm{Fe}_{2}(\mathrm{OH})_{16} \mathrm{CO}_{3}$ $\cdot 4 \mathrm{H}_{2} \mathrm{O}$. In this system, synthetic pyroaurite can be described as $\mathrm{LDH} 6 \mathrm{Mg} 2 \mathrm{Fe} \cdot \mathrm{CO}_{3}-3 R$; synthetic takovite, $\mathrm{Ni}_{6} \mathrm{Al}_{2}(\mathrm{OH})_{16} \mathrm{CO}_{3} \cdot 4 \mathrm{H}_{2} \mathrm{O}$, is $\mathrm{LDH}$ $6 \mathrm{Ni} 2 \mathrm{Al}^{-} \mathrm{CO}_{3}-3 R$. Synthetic LDH phases with no mineralogical equivalent, such as $\mathrm{Mg}_{0.80} \mathrm{Al}_{0.20}$ $(\mathrm{OH})_{2}\left(\mathrm{CO}_{3}\right)_{0.10} \cdot 0.78 \mathrm{H}_{2} \mathrm{O}$ (Kameda et al., 2003), can easily be represented in this system (in this case, as $\left.\mathrm{LDH} 8 \mathrm{Mg} 2 \mathrm{Al} \cdot \mathrm{CO}_{3}-3 R\right)$. More exotic examples are provided by synthetic zincalstibite, $\mathrm{Zn}_{2} \mathrm{Al}(\mathrm{OH})_{6}\left[\mathrm{Sb}(\mathrm{OH})_{6}\right]$, which is $\mathrm{LDH}$ $2 \mathrm{ZnAl} \cdot\left[\mathrm{Sb}(\mathrm{OH})_{6}\right]-1 T ; \mathrm{kuze}^{2} \mathrm{ite}$, $\left[\mathrm{Ca}_{4} \mathrm{Al}_{2}(\mathrm{OH})_{12}\right]\left[\mathrm{SO}_{4}\right] \cdot 6 \mathrm{H}_{2} \mathrm{O}$, which is $\mathrm{LDH}$ $4 \mathrm{Ca} 2 \mathrm{Al} \cdot \mathrm{SO}_{4}-6 R$; and wermlandite, $\left[\mathrm{Mg}_{7} \mathrm{Al}_{2}(\mathrm{OH})_{18}\right]\left[\mathrm{Ca}\left(\mathrm{H}_{2} \mathrm{O}\right)_{6}\right]\left[\mathrm{SO}_{4}\right]_{2} \cdot 6 \mathrm{H}_{2} \mathrm{O}$, which is $\mathrm{LDH} 7 \mathrm{Mg} 2 \mathrm{Al} \cdot \mathrm{SO}_{4}\left[\mathrm{Ca}\left(\mathrm{H}_{2} \mathrm{O}\right)_{6}\right]-1 T$.

Green rust phases have commonly been identified using notation such as ' $\mathrm{GR}\left(\mathrm{CO}_{3}^{2-}\right)$ ' (e.g. Génin et al., 2006a), which similarly only conveys part of the information about the phase. The four green rust phases with $\mathrm{CO}_{3}$ in the interlayer are: $\mathrm{Fe}_{6}^{2+}(\mathrm{OH})_{10}\left(\mathrm{H}_{2} \mathrm{O}\right)_{2} \mathrm{CO}_{3} \cdot 3 \mathrm{H}_{2} \mathrm{O}$, $\mathrm{Fe}_{4}^{2+} \mathrm{Fe}_{2}^{3+}(\mathrm{OH})_{12} \mathrm{CO}_{3} \cdot 3 \mathrm{H}_{2} \mathrm{O}, \mathrm{Fe}_{2}^{2+} \mathrm{Fe}_{4}^{3+} \mathrm{O}_{2}(\mathrm{OH})_{10}$ $\mathrm{CO}_{3} \cdot 3 \mathrm{H}_{2} \mathrm{O}$ and $\mathrm{Fe}_{6}^{3+} \mathrm{O}_{4}(\mathrm{OH})_{8} \mathrm{CO}_{3} \cdot 3 \mathrm{H}_{2} \mathrm{O}$. These can thus be described as LDH $6 \mathrm{Fe}^{2+} 0 \mathrm{Fe}^{3+} \cdot \mathrm{CO}_{3}$ $3 R$; $\mathrm{LDH} 4 \mathrm{Fe}^{2+} 2 \mathrm{Fe}^{3+} \cdot \mathrm{CO}_{3}-3 R$ (fougèrite); $\mathrm{LDH}$ $2 \mathrm{Fe}^{2+} 4 \mathrm{Fe}^{3+} \cdot \mathrm{CO}_{3}-3 R$ (trébeurdenite); and $\mathrm{LDH}$
$0 \mathrm{Fe}^{2+} 6 \mathrm{Fe}^{3+} \cdot \mathrm{CO}_{3}-3 R$ (mössabuerite), respectively. This notation can also easily be adapted for the green rust phases with different interlayer species such as those described by Bernal et al. (1959). However, green rusts are a special case in the supergroup in that (1) the divalent and trivalent cations are the same element; (2) known compositions include ones with only one valency state in the octahedral layer; and (3) examples are known with predominantly trivalent octahedral cations, for which charge balance requires that some hydroxide anions are replaced by oxide. We recommend that the valence state for octahedral cations be included in the notation for these minerals, and that the stoichiometric number " 0 " be used to indicate the absent species explicitly in compositions in which the octahedral cations are all divalent or all trivalent.

Terms such as 'hydrotalcite-like' or 'quinitinite-like' do not contain precise information about the structure or the composition of the phase, and are commonly misleading. The alternative scheme proposed by Drits et al. (1987) suggests names such as ' $8.85-\AA \quad \mathrm{SO}_{4}$-hydrotalcite- $2 H$ ', which include the layer spacing explicitly, but it is mineralogically misleading as such a phase is closer to a woodwardite-group mineral than a member of the hydrotalcite group. In addition, the $M^{2+}: M^{3+}$ ratio and hence the charge on the brucite layer are not apparent in this name. Our proposed system conveys the $M^{2+}: M^{3+}$ ratio and in consequence places quantitative constraints on the interlayer anion content. Therefore, it allows an empirical formula $\left( \pm \mathrm{H}_{2} \mathrm{O}\right)$ to be written, that captures the data of most importance in describing the chemical properties of synthetic LDH phases.

\section{Acknowledgements}

We thank members of the CNMNC for their comments during the submission process and Tony Kampf for comments on the submitted manuscript.

\section{References}

Aïssa, R., François, M., Ruby, C., Fauth, F., Medjahdi, G., Abdelmoula, M. and Génin, J.-M. R. (2006) Formation and crystallographical structure of hydroxysulphate and hydroxycarbonate green rusts synthesized by coprecipitation. Journal of Physical Chemistry of Solids, 67, 1016-1019.

Alker, A., Colob, P., Postl, W. and Waltinger, H. (1981) 
Hydrotalkit, Nordstrandit und Motukoreait vom Stradner Kogel, südlich Gleichenberg, Steiermark. Mitteilungen der Abteilung für Mineralogie des Landesmuseum Joanneum, 49, 1-13.

Allmann, R. (1968) The crystal structure of pyroaurite. Acta Crystallographica, B24, 972-979.

Allmann, R. and Donnay, J.D.H. (1969) About the structure of iowaite. American Mineralogist, 54, 296-299.

Allmann, R. and Jepsen, H.P. (1969) Die struktur des hydrotalkits. Neues Jahrbuch für Mineralogie Monatshefte, 1969, 544-551.

Aminoff, G. and Broomé, B. (1931) Contributions to the mineralogy of Langban. III. Contributions to the knowledge of the mineral pyroaurite. Kungliga Svenska vetenskapsakademiens handlingar, 9, 23-48.

Amphlett, C.B. (1958) Ion exchange in clay minerals. Endeavour, 17, 149-155.

Arakcheeva, A.V., Pushcharovskiy, D.Yu., Rastsvetaeva, R.K., Atencio, D. and Lubman, D.U. (1996) Crystal structure and comparative crystal chemistry of $\mathrm{Al}_{2} \mathrm{Mg}_{4}(\mathrm{OH})_{12}\left(\mathrm{CO}_{3}\right) \cdot 3 \mathrm{H}_{2} \mathrm{O}$, a new mineral from the hydrotalcite-manasseite group. Crystallography Reports, 41, 972-981.

Arden, T.V. (1950) The solubility products of ferrous and ferrosic hydroxides. Journal of the Chemical Society, 1950, 882-885.

Artini, E. (1909) Brugnatellite; nuova specie minerale trovata in Val Malenco. Rendiconti della Regia Accademia Nazionale dei Lincei, 18, 3-6.

Barrer, R.M. (1978) Cation-exchange equilibria in zeolites and feldspathoids. Pp. 385-395 in: Natural Zeolites: Occurrence, Properties, Use (L.B. Sand and F.A. Mumpton, editors). Pergamon Press, New York.

Benali, O., Abdelmoula, M., Refait, Ph. and Génin, J.M.R. (2001) Effect of orthophosphate on the oxidation products of $\mathrm{Fe}(\mathrm{II})-\mathrm{Fe}(\mathrm{III})$ hydroxycarbonate: the transformation of green rust to ferrihydrite. Geochimica et Cosmochimica Acta, 65, 1715-1726.

Bernal, J.D., Dasgupta, D.R. and Mackay, A.L. (1959) The oxides and hydroxides of iron and their structural inter-relationships. Clay Minerals Bulletin, 4, 15-30.

Bertrand, E. and Damour, A. (1881) Zinc-aluminite, nouvelle espèce minérale du Laurium. Bulletin de la Société Française de Minéralogie, 4, 135-136.

Bish, D.L. (1980) Anion-exchange in takovite: applications to other hydroxide minerals. Bulletin de Minéralogie, 103, 170-175.

Bish, D.L. and Brindley, G.W. (1977) Reinvestigation of takovite, a nickel aluminum hydroxy-carbonate of the pyroaurite group. American Mineralogist, 62, $458-464$.

Bish, D.L. and Livingstone, A. (1981) The crystal chemistry and paragenesis of honessite and hydrohonessite. Mineralogical Magazine, 44, 339-343.

Bonaccorsi, E., Merlino, S. and Orlandi, P. (2007) Zincalstibite, a new mineral, and cualstibite: crystal chemical and structural relationships. American Mineralogist, 92, 198-203.

Bookin, A.S. and Drits, V.A. (1993) Polytype diversity of the hydrotalcite-like minerals. I. Possible polytypes and their diffraction features. Clays and Clay Minerals, 41, 551-557.

Bookin, A.S., Cherkashin, V.I. and Drits, V.A. (1993a) Polytype diversity of the hydrotalcite-like minerals. II. Determination of the polytypes of experimentally studied varieties. Clays and Clay Minerals, 41, $558-564$.

Bookin, A.S., Cherkashin, V.I. and Drits, V.A. (1993b) Reinterpretation of the X-ray diffraction patterns of stichtite and reevesite. Clays and Clay Minerals, 41, $631-634$.

Braithwaite, R.S.W., Dunn, P.J., Pritchard, R.G. and Paar, W.H. (1994) Iowaite, a re-investigation. Mineralogical Magazine, 58, 79-85.

Brindley, G.W. (1979) Motukoreaite - additional data and comparison with related minerals. Mineralogical Magazine, 43, 337-340.

Britvin, S.N., Chukanov, N.V., Bekenova, G.K., Tagovkina, M.A., Antonov, A.V., Bogdanova, A.N. and Krasnova, N.I. (2008) Karchevskyite, $\left[\mathrm{Mg}_{18} \mathrm{Al}_{9}(\mathrm{OH})_{54}\right]\left[\mathrm{Sr}_{2}\left(\mathrm{CO}_{3}, \mathrm{PO}_{4}\right)_{9}\left(\mathrm{H}_{2} \mathrm{O}, \mathrm{H}_{3} \mathrm{O}\right)_{11}\right]$, a new mineral species of the layered double hydroxide family. Geology of Ore Deposits, 50, 556-564.

Bryner, V., Rodgers, K.A., Courtney, S.F. and Postl, L. (1991) Motukoreaite from Brown Island, New Zealand, and Stradnerkögel, Austria - a scanning electron microscopic study. Neues Jahrbuch für Mineralogie Abhandlung, 163, 291-304.

Carroll, D. (1959) Ion exchange in clays and other minerals. Geological Society of America Bulletin, 70, $749-779$.

Chao, G.Y. and Gault, R.A. (1997) Quintinite-2H, quintinite-3T, charmarite- $2 H$, charmarite- $3 T$ and caresite-3T, a new group of carbonate minerals related to the hydrotalcite/manasseite group. The Canadian Mineralogist, 35, 1541-1549.

Christiansen, B.C., Balic-Zunic, T., Dideriksen, K. and Stipp, S.L.S. (2009) Identification of green rust in groundwater. Environmental Science and Technology, 43, 3436-3441.

Chukanov, N.V., Pekov, I.V., Levitskaya, L.A. and Zadov, A.E. (2009) Droninoite, $\mathrm{Ni}_{3} \mathrm{Fe}^{3+} \mathrm{Cl}$ $(\mathrm{OH})_{8} \cdot 2 \mathrm{H}_{2} \mathrm{O}$, a new hydrotalcite-group mineral species from the weathered Dronino meteorite. Geology of Ore Deposits, 51, 767-773.

Cooper, M.A. and Hawthorne, F.C. (1996) The crystal structure of shigaite, $\left[\mathrm{A} 1 \mathrm{Mn}_{2}(\mathrm{OH})_{6}\right]_{3}\left(\mathrm{SO}_{4}\right)_{2}$ $\mathrm{Na}\left(\mathrm{H}_{2} \mathrm{O}\right)_{6}\left\{\mathrm{H}_{2} \mathrm{O}\right\}_{6}$, a hydrotalcite-group mineral. 
The Canadian Mineralogist, 34, 91-97.

Dana, E.S. (1892) The System of Mineralogy, sixth edition. Wiley, New York, 962 pp.

De Waal, S.A. and Viljoen, E.A. (1971) Nickel minerals from Barberton, South Africa: IV. Reevesite, a member of the hydrotalcite group. American Mineralogist, 56, 1077-1081.

Dittler, E. and Koechlin, R. (1932) Über Glaukokerinit, ein neues Mineral von Laurion. Centralblatt für Mineralogie, Geologie und Paläontologie, A, 13-17.

Dornberger-Schiff, K. (1982) Geometrical properties of MDO polytypes and procedures for their derivation. I. General concept and applications to polytype families consisting of OD layers all of the same kind. Acta Crystallographica, A38, 438-491.

Drissi, S.H., Refait, Ph., Abdelmoula, M. and Génin, J.M.R. (1995) The preparation and thermodynamic properties of $\mathrm{Fe}(\mathrm{II})-\mathrm{Fe}(\mathrm{III})$ hydroxycarbonate (green rust 1); Pourbaix diagram of iron in carbonatecontaining aqueous media. Corrosion Science, 37, 2025-2041.

Drits, V.A., Sokolova, T.N., Sokolova, G.V. and Cherkashin, V.I. (1987) New members of the hydrotalcite-manasseite group. Clays and Clay Minerals, 35, 401-417.

Duan, X. and Evans, G.D. (2006) Layered Double Hydroxides. Springer, Berlin, $218 \mathrm{pp}$.

Dunn, P.J., Peacor, D.R. and Palmer, T.D. (1979) Desautelsite, a new mineral of the pyroaurite group. American Mineralogist, 64, 127-130.

Evans, D.G. and Slade, R.C.T. (2006) Structural aspects of layered double hydroxides. Pp. 1-87 in: Layered Double Hydroxides (X. Duan and D.G. Evans, editors). Structure and Bonding, 119. Springer, Berlin, 218 pp.

Féder, F., Trolard, F., Klingelhöfer, G. and Bourrié, G. (2005) In situ Mössbauer spectroscopy evidence for green rust (fougerite) in a gleysol and its mineralogical transformations with time and depth. Geochimica et Cosmochimica Acta, 69, 4463-4483.

Feoktistov, G.D., Ivanov, S.I., Kashaev, A.A., Klyuchanskii, L.N., Taskina, N.G. and Ushchapovskaya, Z.F. (1978) The occurrence of chlormanasseite [= chlormagaluminite] in the USSR. Zapiski Rossiiskogo Mineralogicheskogo Obshchestva, 107, 321-325, [in Russian].

Fenoglio, M. (1938) Ricerche sulla brugnatellite. Periodico di Mineralogia, 9, 1-13.

Ferraris, G. and Merlino, S. (editors) (2005) Micro- and Mesoporous Mineral Phases. Reviews in Mineralogy and Geochemistry, 57. Mineralogical Society of America, Washington DC and the Geochemical Society, St Louis, Missouri, USA, 448 pp.

Ferraris, G., Makovicky, E. and Merlino, S. (2004) Crystallography of Modular Materials. IUCr
Monographs on Crystallography, 15. Oxford University Press, Oxford, UK, 370 pp.

Fischer, R., Kuzel, H.-J. and Schellhorn, H. (1980) Hydrocalumit: Mischkristalle von "Friedelschem Salz" $3 \mathrm{CaO} \cdot \mathrm{Al}_{2} \mathrm{O}_{3} \cdot \mathrm{CaCl}_{2} \cdot 10 \mathrm{H}_{2} \mathrm{O}$ und tetracalciumaluminathydrat $3 \mathrm{CaO} \cdot \mathrm{Al}_{2} \mathrm{O}_{3} \cdot \mathrm{Ca}(\mathrm{OH})_{2} \cdot 12 \mathrm{H}_{2} \mathrm{O}$. Neues Jahrbuch für Mineralogie Monatshefte, 1980, $322-334$.

Flink, G. (1901) Mineralogische Notizen. Bulletin of the Geological Institutions of the University of Uppsala, 5, 81-95.

Foshag, W.F. (1920) The chemical composition of hydrotalcite and the hydrotalcite minerals. Proceedings of the United States National Museum, 58, 147-153.

Frondel, C. (1941) Constitution and polymorphism of the pyroaurite and sjögrenite groups. American Mineralogist, 26, 295-316.

Génin, J.-M.R. and Ruby, C. (2008) Structure of some $\mathrm{Fe}^{\mathrm{II}-\mathrm{III}}$ hydroxysalt green rusts (carbonate, oxalate, methanoate) from Mössbauer spectroscopy. Hyperfine Interactions, 185, 191-196.

Génin, J.-M.R., Bauer, Ph., Olowe, A.A. and Rézel, D. (1986) Mössbauer study of the kinetics of simulated corrosion process of iron in chlorinated aqueous solution around room temperature: the hyperfine structure of ferrous hydroxides and green rust I. Hyperfine Interactions, 29, 1355-1360.

Génin, J.-M.R., Olowe, A.A., Refait, Ph. and Simon, L. (1996) On the stoichiometry and Pourbaix diagram of $\mathrm{Fe}(\mathrm{II})-\mathrm{Fe}(\mathrm{III})$ hydroxysulphate or sulphatecontaining green rust 2: An electrochemical and Mössbauer spectroscopy study. Corrosion Science, 38, $1751-1762$.

Génin, J.-M.R., Bourrié, G., Trolard, F., Abdelmoula, M., Jaffrezic, A., Refait, Ph., Maître, V., Humbert, B. and Herbillon, A.J. (1998) Thermodynamic equilibria in aqueous suspensions of synthetic and natural $\mathrm{Fe}^{\mathrm{II}}-\mathrm{Fe}^{\mathrm{III}}$ green rusts: occurrences of the mineral in hydromorphic soils. Environmental Science and Technology, 32, 1058-1068.

Génin, J.-M.R., Refait, Ph. and Abdelmoula, M. (2002) Green rusts and their relationship to iron corrosion; a key role in microbially influenced corrosion. Hyperfine Interactions, 139/140, 119-131.

Génin, J.-M.R., Aïssa, R. Géhin, A., Abdelmoula, M., Benali, O., Ernstsen, V., Ona-Nguema, G., Upadhyay, C. and Ruby, C. (2005) Fougèrite and $\mathrm{Fe}^{\mathrm{II}-\mathrm{III}}$ hydroxycarbonate green rust; ordering, deprotonation and/or cation substitution; structure of hydrotalcite-like compounds and mythic ferrosic hydroxide $\mathrm{Fe}(\mathrm{OH})_{(2+x)}$. Solid State Science, 7, 545-572.

Génin, J.-M.R., Abdelmoula, M., Ruby, C. and Upadhyay, C. (2006a) Speciation of iron; characterisation and structure of green rusts and $\mathrm{Fe}^{\mathrm{II}-\mathrm{III}}$ 
hydroxycarbonate fougerite. Comptes Rendus Geosciences, 338, 402-419.

Génin, J.-M.R., Ruby, C., Géhin, A. and Refait, Ph. (2006b) Synthesis of green rusts by oxidation of $\mathrm{Fe}(\mathrm{OH})_{2}$, their products of oxidation and reduction of ferric oxyhydroxides; $E_{\mathrm{h}}-\mathrm{pH}$ Pourbaix diagrams. Comptes Rendus Geosciences, 338, 433-446.

Génin, J.-M.R., Ruby, C. and Upadhyay, C. (2006c) Structure and thermodynamics of ferrous, stoichiometric and ferric oxyhydroxycarbonate green rusts; redox flexibility and fougerite mineral. Solid State Science, 8, 1330-1343.

Génin, J.-M.R., Renard, A. and Ruby, C. (2008) Fougèrite $\mathrm{Fe}^{\mathrm{II}-\mathrm{III}}$ oxyhydroxycarbonate in environmental chemistry and nitrate reduction. Hyperfine Interactions, 186, 31-37.

Génin, J.-M.R., Guérin, O., Herbillon, A.J., Kuzman, E., Mills, S.J., Morin, G., Ona-Nguema, G., Ruby, C. and Upadhyay, C. (2012a) Redox topotactic reactions in $\mathrm{Fe}^{\mathrm{II}-\mathrm{III}}$ (oxy)-hydroxycarbonate new minerals related to fougerite in gleysols; "trébeurdenite" and "mössbauerite". Hyperfine Interactions, 204, $71-81$.

Génin, J.-M.R., Mills, S.J., Christy, A.G., Guérin, O., Herbillon, A.J., Kuzman, E., Morin, G., OnaNguema, G., Ruby, C. and Upadhyay, C. (2012b) Mössbauerite, $\mathrm{Fe}_{6}^{3+} \mathrm{O}_{4}(\mathrm{OH})_{8} \mathrm{CO}_{3} \cdot 3 \mathrm{H}_{2} \mathrm{O}$, the first fully oxidized 'green rust' mineral from Mont SaintMichel Bay, France. Mineralogical Magazine, 76, (in press).

Girard, A. and Chaudron, G. (1935) Sur la constitution de la rouille. Comptes Rendus Académie des Sciences, Paris, 200, 127-129.

Goh, K.-H., Lim, T.-T. and Dong, Z. (2008) Application of layered double hydroxides for removal of oxyanions: a review. Water Research, 42, $1343-1368$.

Grguric, B.A., Madsen, I.C. and Pring, A. (2001) Woodallite, a new chromium analogue of iowaite from the Mount Keith nickel deposit, Western Australia. Mineralogical Magazine, 65, 427-435.

Guinier, A., Bokij, G.B., Boll-Dornberger, K., Cowley, J.M., Durovič, S., Jagodzinski, H., Krishna, P., de Wolff, P.M., Zvyagin, B.B., Cox, D.E., Goodman, P., Hahn, Th., Kuchitsu, K. and Abrahams, S.C. (1984) Report of the International union of Crystallography ad hoc committee on the nomenclature of disordered, modulated and polytypic structures. Acta Crystallographica, A40, 399-404.

Hager, S.L., Leverett, P. and Williams, P.A. (2009) Possible structural and chemical relationships in the cyanotrichite group. The Canadian Mineralogist, 47, $635-648$.

Hansen, H.C.B. and Taylor, R.M. (1991) Formation of synthetic analogues of double metal-hydroxy carbonate minerals under controlled $\mathrm{pH}$ conditions. II. The synthesis of desautelsite. Clay Minerals, 26, $507-525$.

Hatert, F. and Burke, E.A.J. (2008) The IMA-CNMNC dominant-constituent rule revisited and extended. The Canadian Mineralogist, 46, 717-728.

Hawthorne, F.C., Kimata, M. and Eby, R.K. (1993) The crystal structure of spangolite, a complex copper sulfate sheet mineral. American Mineralogist, 78, $649-652$.

Heddle, M.F. (1879) Geognosy and mineralogy of Scotland. Mineralogical Magazine, 2, 106-133.

Henderson, D.M. and Gutowsky, H.S. (1962) A nuclear magnetic resonance determination of the hydrogen positions in $\mathrm{Ca}(\mathrm{OH})_{2}$. American Mineralogist, 47, $1231-1251$.

Herbillon, A.J. (2006) Ferrosic hydroxides, green rusts and fougerite in the biogeochemical cycle of iron. Comptes Rendus Geosciences, 338, 393-401.

Heyl, A.V., Milton, C. and Axelrod, J.M. (1959) Nickel minerals from near Linden, Iowa County, Wisconsin. American Mineralogist, 44, 995-1009.

Hill, R.J. (1980) The crystal structure of mooreite. Acta Crystallographica, B36, 1304-1311.

Hochstetter, C. (1842) Untersuchung über die Zusammensetzung einiger Mineralien. Journal für Praktische Chemie, 27, 375-378.

Hudson, D.R. and Bussel, M. (1981) Mountkeithite, a new pyroaurite-related mineral with an interlayer containing exchangeable $\mathrm{MgSO}_{4}$. Mineralogical Magazine, 44, 345-350.

Huminicki, D.M.C. and Hawthorne, F.C. (2003) The crystal structure of nikischerite, $\mathrm{NaFeAl}_{3}\left(\mathrm{SO}_{4}\right)_{2}$ $(\mathrm{OH})_{18}\left(\mathrm{H}_{2} \mathrm{O}\right)_{12}$, a mineral of the shigaite group. The Canadian Mineralogist, 41, 79-82.

Huminicki, D.M.C., Hawthorne, F.C., Grice, J.D., Roberts, A.C. and Jambor, J.L. (2003) Nikischerite, a new mineral from the Huanuni tin mine, Dalence Province, Oruro Department, Bolivia. Mineralogical Record, 34, 155-158.

Igelström, L.J. (1865) Nya och sällsynta mineralier från Vermlands och Örebro län. Öfversigt af Kongliga Vetenskaps-Akademiens Förhandlingar, 16, 399-400.

Ingram, L. and Taylor, H.F.W. (1967) The crystal structures of sjögrenite and pyroaurite. Mineralogical Magazine, 36, 465-479.

Jambor, J.L. (1969a) Coalingite from the Muskox Intrusion, Northwest Territories. American Mineralogist, 54, 437-447.

Jambor, J.L. (1969b) Muskoxite, a new hydrous magnesium-ferric iron hydroxide from the Muskox Intrusion, Northwest Territories, Canada. American Mineralogist, 54, 684-696.

Jambor, J.L. and Boyle, R.W. (1964) A nickel hydroxide mineral from Rock Creek, British Columbia. The Canadian Mineralogist, 8, 116-120. 
Kameda, T. and Yoshioka, T. (2011) Hybrid inorganic/ organic composites of layered double hydroxides intercalated with organic acid anions for the uptake of hazardous substances from aqueous solution. Pp. 123-148 in: Metal, ceramic and polymeric composites for various uses (J. Cuppoletti, editor). Intech, Croatia.

Kameda, T., Yoshioka, T., Mitsuhashi, T., Uchida, M. and Okuwaki, A. (2003) The simultaneous removal of calcium and chloride ions from calcium chloride solution using magnesium-aluminum oxide. Water Research, 37, 4045-4050.

Kameda, T., Fubasami, Y. and Yoshioka, T. (2011a) Kinetics and equilibrium studies on the treatment of nitric acid with $\mathrm{Mg}-\mathrm{Al}$ oxide obtained by thermal decomposition of $\mathrm{NO}_{3}^{-}$-intercalated $\mathrm{Mg}-\mathrm{Al}$ layered double hydroxide. Journal of Colloid and Interface Science, 362, 497-502.

Kameda, T., Uchiyama, N. and Yoshioka, T. (2011b) Removal of $\mathrm{HCl}, \mathrm{SO}_{2}$, and $\mathrm{NO}$ by treatment of acid gas with $\mathrm{Mg}-\mathrm{Al}$ oxide slurry. Chemosphere, 82, 587-591.

Kashaev, A.A., Feoktistov, G.D. and Petrova, S.V. (1982) Chlormagaluminite, $\left(\mathrm{Mg}, \mathrm{Fe}^{2+}\right)_{4} \mathrm{Al}_{2}(\mathrm{OH})_{12}$ $\left(\mathrm{Cl}, 1 / 2 \mathrm{CO}_{3}\right)_{2} \cdot 2 \mathrm{H}_{2} \mathrm{O}-$ a new mineral of the manasseite-sjögrenite group. Zapiski Rossiiskogo Mineralogicheskogo Obshchestva, 111, 121-127, [in Russian].

Kohls, D.W. and Rodda, J.L. (1967) Iowaite, a new hydrous magnesium hydroxide-ferric oxychloride from the Precambrian of Iowa. American Mineralogist, 52, 1261-1271.

Kolitsch, U. and Giester, G. (2007) A preliminary determination of the crystal structure of cyanophyllite and revision of its chemical formula. Mitteilungen der Österreichischen Mineralogischen Gesellschaft, 153, 66, [abstract].

Kolitsch, U., Giester, G. and Pippinger, T. (in press) The crystal structure of cualstibite- $1 M$ (formerly cyanophyllite), its revised chemical formula and its relation to cualstibite-1T. Mineralogy and Petrology.

Koritnig, S. and Süsse, P. (1975) Meixnerit, $\mathrm{Mg}_{6} \mathrm{Al}_{2}(\mathrm{OH})_{18} \cdot 4 \mathrm{H}_{2} \mathrm{O}$, ein neues MagnesiumAluminium-Hydroxid-Mineral. Tschermaks Mineralogische und Petrographische Mitteilungen, 22, 79-87.

Krivovichev, S.V., Yakovenchuk, V.N., Zhitova, E.S., Zolotarev, A.A., Pakhomovsky, Y.A. and Ivanyuk, G.Yu. (2010a) Crystal chemistry of natural layered double hydroxides. 1. Quintinite- $2 H-3 c$ from the Kovdor alkaline massif, Kola peninsula, Russia. Mineralogical Magazine, 74, 821-832.

Krivovichev, S.V., Yakovenchuk, V.N., Zhitova, E.S., Zolotarev, A.A., Pakhomovsky, Y.A. and Ivanyuk, G.Yu. (2010b) Crystal chemistry of natural layered double hydroxides. 2. Quintinite-1M. First evidence of a monoclinic polytype in $\mathrm{M}^{2+}-\mathrm{M}^{3+}$ layered double hydroxides. Mineralogical Magazine, 74, 833-840.

Krivovichev, S.V., Yakovenchuk, V.N., Zhitova, E.S., Zolotarev, A.A., Pakhomovsky, Y.A. and Ivanyuk, G.Yu. (2010c) Crystal chemistry of natural layered double hydroxides. 3. The crystal structure of $\mathrm{Mg}, \mathrm{Al}$-disordered quintinite-2H. Mineralogical Magazine, 74, 841-848.

Lapham, D.M. (1965) A new nickeliferous magnesium hydroxide from Lancaster County, Pennsylvania. American Mineralogist, 50, 1708-1716.

Lisitsina, N.A., Drits, V.A., Sokolova, G.V. and Aleksandrova, V.A. (1985) New complex secondary minerals - products of low temperature alteration of sedimentary rocks. Litologia i Poleznie Iskopaemie, 1985, 20-38, [in Russian].

Loewenstein, W. (1954) The distribution of aluminum in the tetrahedra of silicates and aluminates. American Mineralogist, 39, 92-96.

Lozano, R.P., Rossi, C., La Iglesia, A. and Matesanz, E. (2012) Zaccagnaite-3R, a new Zn-Al hydrotalcite polytype from El Soplao cave (Cantabria, Spain). American Mineralogist, 97, 513-523.

Maksimović, Z. (1957) Takovite, hydrous nickel aluminate, a new mineral. Zapisnici Srpskog geološkog društva, 1955, 219-224.

Maksimović, Z. (1958) An essay on the synthesis of nickel hydroaluminate and nickel hydrosilicate under normal conditions. Bulletin of the Scientific Council of the Academy of Sciences of Yugoslavia, 4, $50 \mathrm{pp}$.

Maksimović, Z. (1959) The use of spectrochemical analysis for estimation of exchangable cations in clay minerals. Bulletin Classe des Sciences Mathematiques et Natturalles, 7, 163-165.

Manasse, E. (1915) Rocce eritree e di Aden della collezione Issel. Atti della Società Toscana di Scienze Naturali, Processi Verbali, 24, 92.

Matsubara, S., Kato, A. and Nagashima, K. (1984) Desautelsite from Konomori, Kochi City, Japan. Bulletin of the National Science Museum, 10, 81-86.

Menezes, L.A.D. and Martins, J.M. (1984) The Jacupiranga mine, São Paulo, Brazil. Mineralogical Record, 15, 261-270.

Merlino, S. and Orlandi, P. (2001) Carraraite and zaccagnaite, two new minerals from the Carrara marble quarries: their chemical compositions, physical properties and structural features. American Mineralogist, 86, 1293-1301.

Meyn, M., Beneke, K. and Lagaly, G. (1990) Anionexchange reactions of layered double hydroxides. Inorganic Chemistry, 29, 5201-5207.

Mills, S.J., Hatert, F., Nickel, E.H. and Ferraris, G. (2009) The standardisation of mineral group hierarchies: application to recent nomenclature proposals. European Journal of Mineralogy, 21, 
1073-1080.

Mills, S.J., Whitfield, P.S., Wilson, S.A., Woodhouse, J.N., Dipple, G.M., Raudsepp, M. and Francis, C.A. (2011) The crystal structure of stichtite, re-examination of barbertonite and the nature of polytypism in $\mathrm{MgCr}$ hydrotalcites. American Mineralogist, 96, 179-187.

Mills, S.J., Christy, A.G., Kampf, A.R., Housley, R.M., Favreau, G., Boulliard, J.-C. and Bourgoin, V. (2012a) Zincalstibite-9R: the first 9-layer polytype with the layered double hydroxide structure-type. Mineralogical Magazine, 76, 1337-1345.

Mills, S.J., Kampf, A.R., Housely, R.M., Favreau, G., Pasero, M., Biagioni, C., Merlino, S., Berbain, C. and Orlandi, P. (2012b) Omsite, $(\mathrm{Ni}, \mathrm{Cu})_{2} \mathrm{Fe}^{3+}$ $(\mathrm{OH})_{6}\left[\mathrm{Sb}(\mathrm{OH})_{6}\right]$, a new member of the cualstibite group from Oms, France. Mineralogical Magazine, 76, 1347-1354.

Mills, S.J., Whitfield, P.S., Kampf, A.R., Wilson, S.A., Dipple, G.M., Raudsepp, M. and Favreau, G. (2012c) Contribution to the crystallography of hydrotalcites: the crystal structure of woodallite and takovite. Journal of Geosciences, (in press).

Miyata, S. (1975) Synthesis of hydrotalcite-like compounds and their structures and physicochemical properties. I. The systems $\mathrm{Mg}^{2+}-\mathrm{Al}^{3+}-\mathrm{NO}_{3}^{-}$, $\mathrm{Mg}^{2+}-\mathrm{Al}^{3+}-\mathrm{Cl}^{-}, \quad \mathrm{Mg}^{2+}-\mathrm{Al}^{3+}-\mathrm{ClO}_{4}^{-}$, $\mathrm{Ni}^{2+}-\mathrm{Al}^{3+}-\mathrm{Cl}^{-}$and $\mathrm{Zn}^{2+}-\mathrm{Al}^{3+}-\mathrm{Cl}^{-}$. Clays and Clay Minerals, 23, 369-375.

Miyata, S. and Okada, A. (1977) Synthesis of hydrotalcite-like compounds and their physicochemical properties - the systems $\mathrm{Mg}^{2+}-\mathrm{Al}^{3+}-\mathrm{SO}_{4}^{2-}$ and $\mathrm{Mg}^{2+}-\mathrm{Al}^{3+}-\mathrm{CrO}_{4}^{2-}$. Clays and Clay Minerals, 25, 14-18.

Moore, P.B. (1971) Wermlandite, a new mineral from Långban, Sweden. Lithos, 4, 213-217.

Morandi, N. and Dalrio, G. (1973) Jamborite: a new nickel hydroxide mineral from the northern Appenines, Italy. American Mineralogist, 58, 835-839.

Mumpton, F.A., Jaffe, H.W. and Thompson, C.S. (1965) Coalingite, a new mineral from the New Idria serpentinite, Fresno and San Benito Counties, California. American Mineralogist, 50, 1893-1913.

Newman, S.P. and Jones, W. (1998) Synthesis, characterization and applications of layered double hydroxides containing organic guests. New Journal of Chemistry, 22, 105-115.

Nickel, E.H. (1976) New data on woodwardite. Mineralogical Magazine, 43, 644-647.

Nickel, E.H. and Clarke, R.M. (1976) Carrboydite, a hydrated sulfate of nickel and aluminum: a new mineral from Western Australia. American Mineralogist, 61, 366-372.

Nickel, E.H. and Grice, J.D. (1998) The IMA Commission on New Minerals and Mineral Names: procedures and guidelines on mineral nomenclature, 1998. The Canadian Mineralogist, 36, 913-926.

Nickel, E.H. and Wildman, J.E. (1981) Hydrohonessite - a new hydrated $\mathrm{Ni}-\mathrm{Fe}$ hydroxy-sulphate mineral; its relationship to honessite, carrboydite, and minerals of the pyroaurite group. Mineralogical Magazine, 44, 333-337.

Ona-Nguema, G., Abdelmoula, M., Jorand, F., Benali, O., Géhin, A., Block, J.C. and Génin, J.-M.R. (2002) Iron (II,III) hydroxycarbonate green rust formation and stabilization from lepidocrocite bioreduction Environmental Science and Technology, 36, 16-20.

Palache, C., Berman, H. and Frondel, C. (1951) Dana's System of Mineralogy, seventh edition. Wiley, New York.

Parise, J.B., Theroux, B., Li, R., Loveday, J.S., Marshall, W.G. and Klotz, S. (1998) Pressure dependence of hydrogen bonding in metal deuteroxides: a neutron powder diffraction study of $\mathrm{Mn}(\mathrm{OD})_{2}$ and beta$\mathrm{Co}(\mathrm{OD})_{2}$. Physics and Chemistry of Minerals, 25, $130-137$.

Passaglia, E. and Sacerdoti, M. (1988) Hydrocalumite from Montalto di Castro, Viterbo, Italy. Neues Jahrbuch für Mineralogie Monatshefte, 1988, 454-461.

Pastor-Rodriguez, J. and Taylor, H.F.W. (1971) Crystal structure of coalingite. Mineralogical Magazine, 38, 286-294.

Pausch, I., Lohse, H.-H., Schürmann, K. and Allmann, R. (1986) Synthesis of disordered and Al-rich hydrotalcite-like compounds. Clays and Clay Minerals, 34, 507-510.

Peacor, D.R., Dunn, P.J., Kato, A. and Wicks, F.J. (1985) Shigaite, a new manganese aluminum sulphate mineral from the Ioi mine, Shiga, Japan. Neues Jahrbuch für Mineralogie Monatshefte, 1985, $453-457$.

Pertlik, F. and Dunn, P.J. (1990) Crystal structure of alvanite, $(\mathrm{Zn}, \mathrm{Ni}) \mathrm{Al}_{4}\left(\mathrm{VO}_{3}\right)_{2}(\mathrm{OH})_{12} \cdot 2 \mathrm{H}_{2} \mathrm{O}$, the first example of an unbranched zweier-single chain vanadate in nature. Neues Jahrbuch für Mineralogie Monatshefte, 1990, 385-392.

Petterd, W.F. (1910) Catalog of the minerals of Tasmania. Mines Department Publication Hobart, Tasmania, Australia.

Piret, P. and Deliens, M. (1980) La comblainite, $\left(\mathrm{Ni}_{\mathrm{x}}^{2+} \mathrm{Co}_{1-\mathrm{x}}^{3+}\right)(\mathrm{OH})_{2}\left(\mathrm{CO}_{3}\right)_{(1-\mathrm{x}) / 2} \cdot y \mathrm{H}_{2} \mathrm{O}$, noveau minéral du groupe de la pyroaurite. Bulletin de Minéralogie, 103, 113-117.

Pollmann, H., Witzke, T. and Kohler, H. (1997) Kuzelite, $\left[\mathrm{Ca}_{4} \mathrm{Al}_{2}(\mathrm{OH})_{12}\right]\left[\left(\mathrm{SO}_{4}\right) \cdot 6 \mathrm{H}_{2} \mathrm{O}\right]$, a new mineral from Maroldsweisach/Bavaria, Germany. Neues Jahrbuch für Mineralogie Monatshefte, 1997, 423-432.

Raade, G., Elliott, C.J. and Din, V.K. (1985) New data on glaucocerinite. Mineralogical Magazine, 49, 
$583-590$.

Rad, U. (1974) Great Meteor and Josephine Seamounts (eastern North Atlantic): Composition and origin of bioclastic sands, carbonate and pyroclastic rocks. "Meteor" Forschungergebnisse I, 9, 1-6.

Ramanaidou, E. and Noack, Y. (1987) Palagonites of the Red Sea: a new occurrence of hydroxysulphate. Mineralogical Magazine, 51, 139-143.

Ramesh, T.N., Kamath, P.V. and Shivakumara, C. (2006) Classification of stacking faults and their stepwise elemination during the disorder $\rightarrow$ order transformation of nickel hydroxide. Acta Crystallographica, B62, 530-536.

Refait, Ph., Memet, J.B., Bon, C., Sabot, R. and Génin, J.-M.R. (2003) Formation of the Fe(II)-Fe(III) hydroxysulphate green rust during marine corrosion of steel. Corrosion Science, 45, 833-845.

Richardson, M.C. and Braterman, P.S. (2007) Infrared spectra of oriented and nonoriented layered double hydroxides in the range from 4000 to $250 \mathrm{~cm}^{-1}$, with evidence for regular short-range order in a synthetic magnesium-aluminum $\mathrm{LDH}$ with $\mathrm{Mg}: \mathrm{Al}=2: 1$ but not with Mg:Al = 3:1. Journal of Physical Chemistry, C111, 4209-4215.

Rius, J. and Allmann, R. (1984) The superstructure of the double layer mineral wermlandite $\left[\mathrm{Mg}_{7}\left(\mathrm{Al}_{0.57} \mathrm{Fe}_{0.43}^{3+}\right)_{2}(\mathrm{OH})_{18}\right]^{2+}\left[\left(\mathrm{Ca}_{0.6} \mathrm{Mg}_{0.4}\right)\right.$ $\left.\left(\mathrm{SO}_{4}\right)_{2}\left(\mathrm{H}_{2} \mathrm{O}\right)_{12}\right]^{2-}$. Zeitschrift für Kristallographie, 168, 133-144.

Rius, J. and Plana, F. (1986) Contribution to the superstructure resolution of the double layer mineral motukoreaite. Neues Jahrbuch für Mineralogie Monatshefte, 1986, 263-272.

Rodgers, K.A., Chisholm, J.E., David, R.J. and Nelson, C.S. (1977) Motukoreaite, a new hydrated carbonate, sulphate, and hydroxide of $\mathrm{Mg}$ and $\mathrm{Al}$ from Auckland, New Zealand. Mineralogical Magazine, 41, 389-390.

Rodionov, D., Klingelhöfer, G., Bernhardt, B., Schroder, C., Blumers, M., Kane, S., Trolard, F., Bourrié, G. and Génin, J.-M.R. (2006) Automated Mössbauer spectroscopy in the field and monitoring of fougerite. Hyperfine Interactions, 167, 869-873.

Ross, G.J. and Kodama, H. (1967) Properties of a synthetic magnesium-aluminum carbonate hydroxide and its relationship to magnesium-aluminum double hydroxide, manasseite and hydrotalcite. American Mineralogist, 52, 1036-1047.

Rouxhet, P.G. and Taylor, H.F.W. (1969) Thermal decomposition of sjögrenite and pyroaurite. Chimia, 23, 480-485.

Ruby, C., Upadhyay, C., Géhin, A., Ona-Nguema, G. and Génin, J.-M.R. (2006) In situ redox flexibility of $\mathrm{Fe}^{\mathrm{II}-\mathrm{III}}$ oxyhydroxycarbonate green rust and fougerite. Environmental Science and Technology, 40, 4696-4702.
Ruby, C., Abdelmoula, M., Naille, S., Renard, A., Khare, V., Ona-Nguema, G., Morin, G. and Génin, J.-M.R. (2010) Oxidation modes and thermodynamics of $\mathrm{Fe}^{\mathrm{II}-\mathrm{III}}$ oxyhydroxycarbonate green rust: dissolution-precipitation versus in-situ deprotonation. Geochimica et Cosmochimica Acta, 74, 953-966.

Rusch, B., Génin, J.-M.R., Ruby, C., Abdelmoula, M. and Bonville, P. (2008) Ferrimagnetic properties in $\mathrm{Fe}^{\mathrm{II}}-\mathrm{Fe}^{\mathrm{III}}$ (oxy)hydroxycarbonate green rusts. Solid State Sciences, 10, 40-49.

Sacerdoti, M. and Passaglia, E. (1988) Hydrocalumite from Latium, Italy - its crystal structure and relationship with related synthetic phases. Neues Jahrbuch für Mineralogie Monatshefte, 1988, 462-475.

Sideris, P.J., Nielsen, U.G., Gan, Z.H. and Grey, C.P. (2008) $\mathrm{Mg} / \mathrm{Al}$ ordering in layered double hydroxides revealed by multinuclear NMR spectroscopy. Science, 321, 113-117.

Simon, L., François, M., Refait, Ph., Renaudin, G., Lelaurain, M. and Génin, J.-M.R. (2003) Structure of the $\mathrm{Fe}^{(\mathrm{II}-\mathrm{III})}$ layered double hydroxysulphate green rust two from Rietveld analysis. Solid State Sciences, 5, 327-334.

Sjögren, H. (1894) Contributions to Swedish Mineralogy. Part II. Bulletin of the Geological Institutions of the University of Uppsala, 2, 39-74.

Smith, D.G.W. and Nickel, E.H. (2007) A system of codification for unnamed minerals: report of the subcommittee for unnamed minerals of the IMA Commission on New Minerals, Nomenclature and Classification. The Canadian Mineralogist, 45, 983-1055.

Song, Y. and Moon, H.S. (1998) Additional data on reevesite and its Co-analogue, as a new member of the hydrotalcite group. Clay Minerals, 33, 285-296.

Stanimirova, T. (2001) Hydrotalcite polytypes from Snarum, Norway. Annual of the University of Sofia, Faculty of Geology, 94, 73-80.

Steeds, J.W. and Morniroli, J.P. (1992) Selected area electron diffraction (SAED) and convergent beam diffraction (CBED). Pp. 37-84 in: Minerals and Reactions at the Atomic Scale: Transmission Electron Microscopy (P.R. Buseck, editor). Reviews in Mineralogy, 27. Mineralogical Society of America, Washington DC.

Tatarinov, A.V., Sapozhnikov, A.N., Prokudin, S. and Frolova, L.P. (1985) Stichtite in serpentinites of the Terekinsky Ridge (Gornyi Altai). Zapiski Rossiiskogo Mineralogicheskogo Obshchestva, 114, 575-581, [in Russian].

Taylor, H.F.W. (1969) Segregation and cation-ordering in sjögrenite and pyroaurite. Mineralogical Magazine, 37, 338-342.

Taylor, H.F.W. (1973) Crystal structures of some double 
hydroxide minerals. Mineralogical Magazine, 39, 377-389.

Taylor, R.M. (1980) Formation and properties of Fe(II) $\mathrm{Fe}(\mathrm{III})$ hydroxycarbonate and its possible significance in soil formation. Clay Minerals, 15, 369-372.

Tilley, C.E., Megaw, H.D. and Hey, M.H. (1934) Hydrocalumite $\left(4 \mathrm{CaO} \cdot \mathrm{Al}_{2} \mathrm{O}_{3} \cdot 12 \mathrm{H}_{2} \mathrm{O}\right)$. A new mineral from Scawt Hill, County Antrim. Mineralogical Magazine, 23, 607-615.

Trolard, F., Génin, J.-M.R., Abdelmoula, M., Bourrié, G., Humbert, B. and Herbillon, A.J. (1997) Identification of a green rust mineral in a reductomorphic soil by Mössbauer and Raman spectroscopies. Geochimica et Cosmochimica Acta, 61, 1107-1111.

Trolard, F., Bourrié, G., Abdelmoula, M., Refait, Ph. and Féder, F. (2007) Fougerite, a new mineral of the pyroaurite-iowaite group: description and crystal structure. Clays and Clay Minerals, 55, 323-334.

Uvarova, Y.A., Sokolova, E., Hawthorne, F.C., Karpenko, V.V., Agakhanov, A. and Pautov, L.A. (2005) The crystal chemistry of the "nickelalumite"group minerals. The Canadian Mineralogist 43, 1511-1519.

Vysostskii, G.N. (1905) Gley. Eurasian Soil Science (Pochvovedenie), 4, 291-327.

Walenta, K. (1981) Cyanophyllit, ein neues Mineral aus der Grube Clara bei Oberwolfach im mittleren Schwarzwald. Chemie der Erde, 40, 195-200.

Walenta, K. (1984) Cualstibit, ein neues Sekundärmineral aus der Grube Clara im mittleren Schwarzwald (BRD). Chemie der Erde, 43, 255-260.

White, J.S. Jr, Henderson, E.P. and Mason, B. (1967) Secondary minerals produced by weathering of the Wolf Creek meteorite. American Mineralogist, 52, 1190-1197.
Whitfield, P.S., Davidson, I.J., Mitchell, L.D., Wilson, S.A. and Mills, S.J. (2010) Problem solving with the TOPAS macro language: corrections and constraints in simulated annealing and Rietveld refinement. Materials Science Forum, 651, 11-25.

Witzke, T. (1995) Untersuchung natürlicher sulfathaltiger hybrider Schichtstrukturen: Charakterisierung, Systematik, Strukturmodellierung und RietveldVerfeinerung. PhD Thesis, Martin-LutherUniversität Halle, Germany.

Witzke, T. (1999) Hydrowoodwardite, a new mineral of the hydrotalcite group from Königswalde near Annaberg, Saxony/Germany and other localities. Neues Jahrbuch für Mineralogie Monatshefte, 1999, 75-86.

Witzke, T. and Raade, G. (2000) Zincowoodwardite, $\left[\mathrm{Zn}_{1-\mathrm{x}} \mathrm{Al}_{\mathrm{x}}(\mathrm{OH})_{2}\right]\left[\left(\mathrm{SO}_{4}\right)_{\mathrm{x} / 2}\left(\mathrm{H}_{2} \mathrm{O}\right)_{\mathrm{n}}\right]$, a new mineral of the hydrotalcite group. Neues Jahrbuch für Mineralogie Monatshefte, 2000, 455-465.

Witzke, T., Pöllmann, H. and Vogel, A. (1995) Struktur und Synthese von $\left.\left[\mathrm{Zn}_{8-\mathrm{x}} \mathrm{AlOH}\right)_{16}\right]\left[\left(\mathrm{SO}_{4}\right)_{\mathrm{X} / 2+\mathrm{Y} / 2}\right.$ $\left.\mathrm{Na}_{\mathrm{Y}}\left(\mathrm{H}_{2} \mathrm{O}\right)_{6}\right]$. Zeitschrift für Kristallographie, Supplemental Issue, 9, 252.

Woodhouse, J.N. (2006) The characterization of hydrotalcite-group minerals and their anion exchange capabilities at Mount Keith Nickel mine, Western Australia. Unpublished BSc. Thesis, The University of British Columbia, Vancouver, Canada. Wyckoff, R.W.G. (1963) Crystal Structures, second edition. Interscience Publishers, New York.

Zamarreño, I., Plana, F., Vasquez, A. and Clague, D.A. (1989) Motukoreaite: a common alteration product in submarine basalts. American Mineralogist, 74, 1054-1058.

Zigan, F. and Rothbauer, R. (1967) Neutronenbeugungsmessungen am Brucit. Neues Jahrbuch für Mineralogie Monatshefte, 1967, 137-143. 